University of New Mexico

UNM Digital Repository

Civil Engineering ETDs

Engineering ETDs

Summer 7-14-2018

\title{
METAL REACTIVITY IN LABORATORY BURNED WOOD FROM A WATERSHED AFFECTED BY WILDFIRES
}

Asifur Rahman

University of New Mexico - Main Campus

Follow this and additional works at: https://digitalrepository.unm.edu/ce_etds

Part of the Environmental Engineering Commons

\section{Recommended Citation}

Rahman, Asifur. "METAL REACTIVITY IN LABORATORY BURNED WOOD FROM A WATERSHED AFFECTED BY WILDFIRES." (2018). https://digitalrepository.unm.edu/ce_etds/216

This Thesis is brought to you for free and open access by the Engineering ETDs at UNM Digital Repository. It has been accepted for inclusion in Civil Engineering ETDs by an authorized administrator of UNM Digital Repository. For more information, please contact disc@unm.edu. 
Asifur Rahman

Candidate

Civil Engineering

Department

This thesis is approved, and it is acceptable in quality and form for publication:

Approved by the Thesis Committee:

Dr. José M. Cerrato, Chairperson

Dr. Abdul Mehdi Ali

Dr. Mark C. Stone

Dr. Rebecca Bixby 


\title{
METAL REACTIVITY IN LABORATORY BURNED WOOD
} FROM A WATERSHED AFFECTED BY WILDFIRES

\author{
by
}

\section{ASIFUR RAHMAN}

B. Sc. in WATER RESOURCES ENGINEERING

\section{THESIS}

Submitted in Partial Fulfillment of the

Requirements for the Degree of

\author{
Masters of Science \\ Civil Engineering
}

The University of New Mexico

Albuquerque, New Mexico

July 2018 


\section{Acknowledgements}

I would like to convey my appreciation to Dr. José M. Cerrato, my advisor and committee chairperson, for his mentorship and guidance in my research. His leadership and supervision helped me in completion of the master's research work. I want to express my gratitude to the different funding agencies (ORAU, NM EPSCoR, NMWRRI and CREST) providing support for this work.

I would also thank Dr. Abdul Mehdi Ali for his immense support and guidance at different stages of this work and with instrumentation and analytical procedures. I would like to thank Dr. Rebecca Bixby and Dr. Mark Stone for their invaluable advice and help with logistics of this work. I would thank my committee members: Dr. Cerrato, Dr. Mehdi Ali, Dr. Bixby and Dr. Stone, again, for their patience, understanding and guidance through my research and towards my graduation.

I must also thank the collaborators for this research work. Special thanks to Eliane El Hayek, for her mentorship and guidance, which proved instrumental for the direction of this research work. Thanks to Johanna M. Blake for the guidance and support in preparation of the manuscript for publication of this work. For microscopy, spectroscopy and elemental analysis, I thank our collaborators: Michael Spilde, Kateryna Artyushkova and Viorel Atudorei. I appreciate the help by Cyrena Ridgeway with the laboratory batch experiments. Amanda A. Otieno and Keely Miltenberger provided valuable contribution with field measurements of soil and water chemistry data.

Finally, I must thank my father Md. Shahidur Rahman, mother Sharifa Rahman, brothers Arifur Rahman, Ashiqur Rahman and Saifur Rahman for their boundless love, patience and support for my success and ambitions. 


\title{
METAL REACTIVITY IN LABORATORY BURNED WOOD FROM A WATERSHED AFFECTED BY WILDFIRES
}

by

\author{
Asifur Rahman \\ B.Sc. in Water Resources Engineering, 2012
}

M.S. in Civil Engineering, 2018

\begin{abstract}
Massive amounts of wood ash are deposited into nearby streams as a result of runoff from storm events after increasing frequency of wildfire events that negatively affect water quality. Ash and debris from burned vegetation can alter the $\mathrm{pH}$, turbidity and dissolved oxygen (DO) in water and can release heavy metals, organic matter, and nutrients. We investigated interfacial processes affecting metal mobility in wood ash burned under laboratory-controlled conditions using aqueous chemistry, microscopy and spectroscopy analyses. Wood was collected from the Valles Caldera National Preserve in New Mexico which has experienced two wildfires since 2011 that have caused devastating effects. Wood samples (e.g. Ponderosa Pine, Quaking Aspen, and Colorado Blue Spruce) collected from this site were exposed to temperatures of $60^{\circ} \mathrm{C}, 350^{\circ} \mathrm{C}$ and $550^{\circ} \mathrm{C}$. Pine ashes burned at $350^{\circ} \mathrm{C}$ and $550^{\circ} \mathrm{C}$ were associated with high concentrations of metals (i.e., $\mathrm{Cu}, \mathrm{Cr}, \mathrm{Si}, \mathrm{Ni}, \mathrm{Fe}, \mathrm{K}$ and $\mathrm{Mg}$ ). Pine ash burned at $350^{\circ} \mathrm{C}$ had the highest content of $\mathrm{Cu}\left(4997+262 \mathrm{mg} \mathrm{kg}^{-1}\right), \mathrm{Cr}\left(543+124 \mathrm{mg} \mathrm{kg}^{-1}\right)$, and labile dissolved organic carbon (DOC, $\left.11.3+0.28 \mathrm{mg} \mathrm{L}^{-1}\right)$. Metal sorption experiments were conducted by reacting $350^{\circ} \mathrm{C}$ Pine ash separately with $10 \mu \mathrm{M}$ solutions of $\mathrm{Cu}(\mathrm{II})$ and $\mathrm{Cr}(\mathrm{VI})$, as examples of a cation and an oxyanion found in high concentrations in water following wildfire events near VALL. High decrease in $\mathrm{Cu}(\mathrm{II})$ concentration (up to $92 \%$ ) was observed in solution while $\mathrm{Cr}$ (VI) showed limited decrease (up to $13 \%$ ) in concentration after 180 mins of reaction. X-ray photoelectron spectroscopy (XPS)
\end{abstract}


analyses detected increased association of $\mathrm{Cu}(\mathrm{II})$ on the near surface region of the reacted ash from the sorption experiments compared to the unreacted ash. The results from this investigation suggest that dissolution and sorption processes are essential to understand the transport of metals in water following wildfires. This study provides relevant insights about the potential effects of metals transported by wood ash on water quality that have important implications for post-fire recovery and response strategies 


\section{Table of Contents}

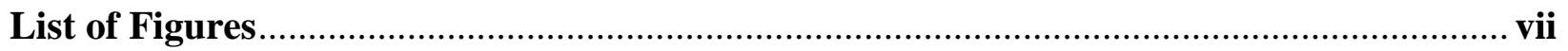

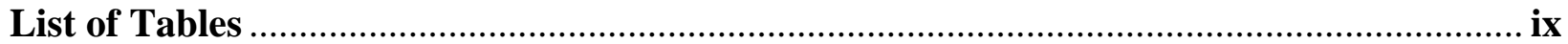

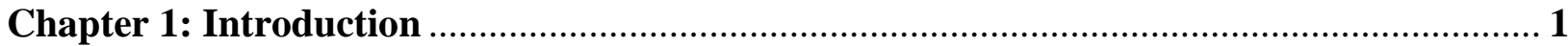

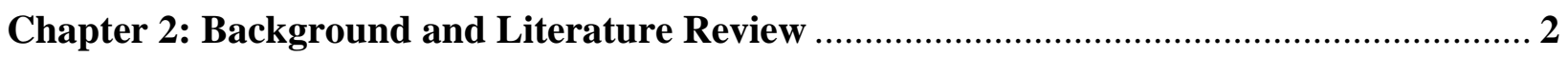

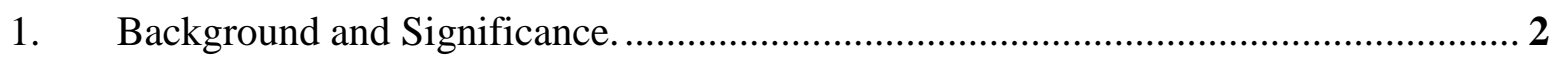

2. Wildfire Ash and Water Chemistry...................................................................... 4

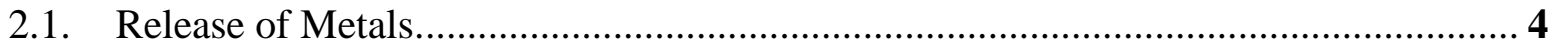

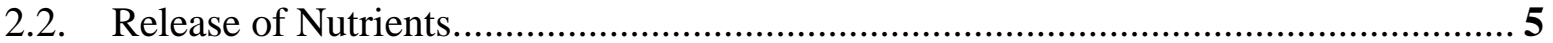

2.3. Elevated levels of Dissolved Organic Carbon (DOC) and Disinfection Byproducts

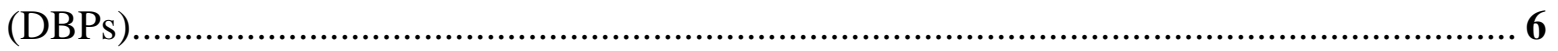

2.4. Change in water quality parameters $(\mathrm{pH}, \mathrm{DO}$, turbidity) ………………………........ 6

3. Characteristics of wood ash at different burn intensity and severity............................ 7

3.1. Physical and hydrological properties of ash. ........................................................ 7

3.2. Chemical and mineralogical properties of ash. ................................................... 8

3.3. Effects of temperature on ash chemical and mineralogical properties........................ 8

4. Mechanisms Affecting Wood Ash Reactivity......................................................... 9

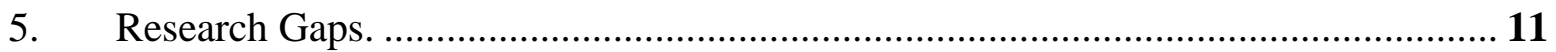

Chapter 3: Metal Reactivity in Laboratory Burned Wood from a Watershed Affected by

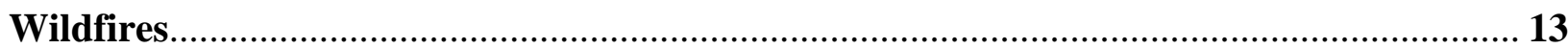

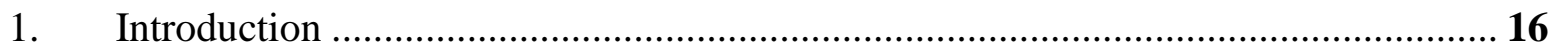

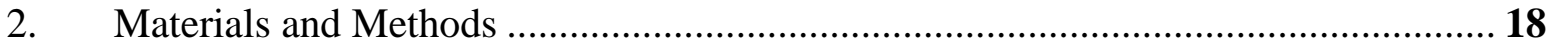

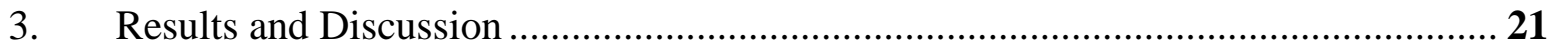

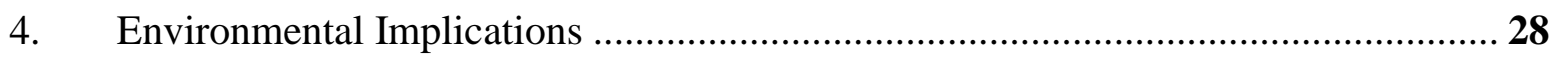

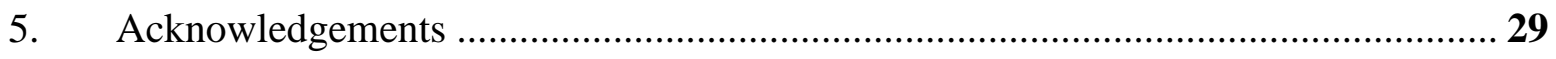

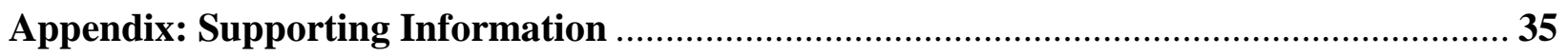

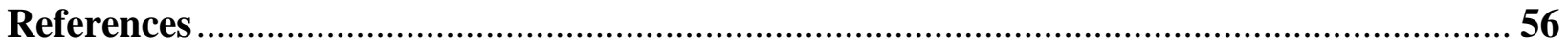




\section{List of Figures}

Figure 1. The nature of the threat from wildfire ash, including a look at different properties of wood ash

Figure 2. TOC figure showing the cycle from laboratory burning to metal sorption experiments.

Figure 3. Acid extractable concentrations (mean \pm SD) of 9 metals varied across different tree species of (a) Pine, (b) Spruce and (c) Aspen. The major elements ( $\mathrm{Ca}, \mathrm{Mg}$ and $\mathrm{K}$ ) were predominant in all tree species at $60^{\circ} \mathrm{C}, 350^{\circ} \mathrm{C}$ and $550^{\circ} \mathrm{C}$ (Table S2). Ash produced at both $350^{\circ} \mathrm{C}$ (moderate burn) and $550^{\circ} \mathrm{C}$ (high burn) contained higher metal concentrations than in samples dried at $60^{\circ} \mathrm{C}$ (unburned) for all species.

Figure 4. Concentrations of (a) $\mathrm{Fe}, \mathrm{Cu}, \mathrm{Zn}$ and (b) $\mathrm{Cr}, \mathrm{Ni}$ at $0,4,24$ and 72 hours in reaction of $550^{\circ} \mathrm{C}$ Pine ash with $18 \mathrm{M} \Omega$ water. In figures (c) and (d), metal concentrations are shown for reaction of $350^{\circ} \mathrm{C}$ Pine ash with $18 \mathrm{M} \Omega$ water. DOC concentration (mg carbon $\mathrm{L}^{-1}$ ) at $0,4,24$ and 72 hours $(\mathrm{n}=3)$ is shown in figure (e) for $350^{\circ} \mathrm{C}$ and $550^{\circ} \mathrm{C}$ ash samples and in (f) $60^{\circ} \mathrm{C}$ crushed wood samples.

Figure 5. Results from the metal sorption experiments $(\mathrm{n}=3$, sampling interval $=5 \mathrm{~min}, 15 \mathrm{~min}$, $30 \mathrm{~min}, 1 \mathrm{hr}, 2 \mathrm{hrs}$ and $3 \mathrm{hrs}$ ) conducted by reacting $10 \mu \mathrm{M}$ of (a) $\mathrm{Cu}$ (II) and (b) $\mathrm{Cr}$ (VI) separately in a solution containing $0.1 \mathrm{~g}$ of $350^{\circ} \mathrm{C}$ Pine ash with $50 \mathrm{~mL}$ of $18 \mathrm{M} \Omega$ water. Note that the control experiments were conducted by reacting $10 \mu \mathrm{M}$ of $\mathrm{Cu}(\mathrm{II})$ and $\mathrm{Cr}(\mathrm{VI})$ in $18 \mathrm{M} \Omega$ water without ash.

Figure 6. $\mathrm{Cu} 2 \mathrm{p}$ high resolution spectra for the (a) Reacted $350^{\circ} \mathrm{C}$ Pine ash and (b) Unreacted $350^{\circ} \mathrm{C}$ Pine ash (c) Percentages of different oxidation states in the $\mathrm{Cu} 2 \mathrm{p}$ spectra for the reacted ash determined by using reference $\mathrm{Cu} 2 \mathrm{p}$ spectra for $\mathrm{CuO}, \mathrm{CuCO}_{3}, \mathrm{Cu}_{2} \mathrm{O}$ and $\mathrm{Cu}$ metal.......... 34 Figure S1. Map showing the sampling locations for (a) wood, (b) water and soil and (c) soil samples in Valles Caldera. The co-ordinates of the sampling locations are shown beside the map. This site map is adapted from the map published in a previous study by Cerrato et al. ${ }^{23}$ .46

Figure S2. Principal component analysis was run on metal concentrations for $350^{\circ} \mathrm{C}$ and $550^{\circ} \mathrm{C}$ triplicate measurements of ash samples (Pine, Spruce, Aspen). The first two principal components explained $91.34 \%$ of the total variance. The metals such as $\mathrm{Al}, \mathrm{Cr}, \mathrm{Cu}, \mathrm{Fe}, \mathrm{Mn}$ and Si showed high positive loadings on PC 1; and PC 2 showed high positive loadings for the major elements ( $\mathrm{Ca}, \mathrm{K}, \mathrm{Mg}$ ) and metals such as $\mathrm{Ni}, \mathrm{Sr}$ and $\mathrm{Zn}$. Coefficients of the metals on the principal components are shown in the table. The figure also shows the component scores of the Pine, Spruce and Aspen ash samples. $350^{\circ} \mathrm{C}$ and $550^{\circ} \mathrm{C}$ Pine ash samples had positive scores on the both the principal components.

Figure S3. $\mathrm{pH}$ and alkalinity measured at $0,4,24$ and 72 hours are shown in figure (a) and (b) respectively. In figure (a), the open symbols represent the $\mathrm{pH}$ of $18 \mathrm{M} \Omega$ water.

Figure S4. XRD patterns of the (a) reacted and the (b) unreacted $350^{\circ} \mathrm{C}$ Pine ash sample from the batch sorption experiments with $\mathrm{Cu}(\mathrm{II})$. The two samples are very similar in terms of crystalline 
composition which is predominantly calcite (78-79\%) with lesser amounts of quartz (11-12\%) and whewellite $(9-11 \%)$.

Figure S5. Zeta Potential (mV) measurements of (a) Pine $350^{\circ} \mathrm{C}$ ash, (b) Spruce $350^{\circ} \mathrm{C}$ ash and (c) Aspen $350^{\circ} \mathrm{C}$ ash in different solution $\mathrm{pH}$ values. The reported values are the average of three measurements.

Figure S6. Results from the metal sorption experiments $(n=3$, sampling interval $=5$ min, 15 min, $30 \mathrm{~min}, 1 \mathrm{hr}, 2 \mathrm{hrs}$ and $3 \mathrm{hrs}$ ) conducted by reacting $10 \mu \mathrm{M}$ of (a) $\mathrm{Cu}$ (II) and (b) $\mathrm{Cr}$ (VI) separately in a solution containing $0.1 \mathrm{~g}$ of $350^{\circ} \mathrm{C}$ Spruce ash with $50 \mathrm{~mL}$ of $18 \mathrm{M} \Omega$ water. Figures (c) and (d) show the same analysis with Aspen ash. Results from the control experiments without the ash are included in all the figures. 51

Figure S7. SEM images of the (a) unreacted and the (b) reacted $350^{\circ} \mathrm{C}$ Pine ash from the batch sorption experiments with $\mathrm{Cu}(\mathrm{II})$. EDS spectrum from a $\mathrm{Cu}$ grain on both the ash samples shows presence of $\mathrm{Cu}$ peaks. The atomic wt.\% distribution for the respective spectrum is also shown for a specific $\mathrm{Cu}$ grain highlighted in red circle.

Figure S8. Microprobe mapping of $\mathrm{Mg}, \mathrm{P}, \mathrm{O}, \mathrm{Ca}$ and $\mathrm{Cu}$ on the (a) reacted and (b) unreacted $350^{\circ} \mathrm{C}$ Pine ash. Microprobe analysis showed presence of low level of detectable $\mathrm{Cu}$ associated with mineralized $\mathrm{Ca}$ in the reacted ash, shown in figure (c). In table (d), the wt\% of the elements associated with the mineralized $\mathrm{Ca}$ region is shown. At $95 \%$ confidence level, the $\mathrm{Cu}$ in the reacted sample is detectable at $0.012 \mathrm{wt} \%$ but below detection limit in the unreacted sample. Detection limit for $\mathrm{Cu}$ at $95 \%$ confidence level was $0.009 \mathrm{wt} \%$.

Figure S9. XPS high resolution C 1s spectra for the (a) Unreacted $350^{\circ} \mathrm{C}$ Pine ash sample and (b) the reacted $350^{\circ} \mathrm{C}$ Pine ash sample. (c) Percent compositions of the $\mathrm{C} 1 \mathrm{~s}$ spectra for the unreacted and the reacted ash.

Figure 10. XPS high-resolution $\mathrm{Cu} 2 \mathrm{p}$ spectra for (a) $\mathrm{Cu}$ metal, (b) $\mathrm{Cu}_{2} \mathrm{O}$ (I), (c) $\mathrm{CuO}$ (II) and (d) $\mathrm{CuCO}_{3}$ (II). (e) The binding energies obtained for the $\mathrm{Cu} 2 \mathrm{p}$ regions for these reference materials are shown 


\section{List of Tables}

Table 1. Elemental content of water ( Fork Jemez River within the Valle Grande area in VALL. Site V4 to V6 contain soil samples from the hill slope of the Sierra de Los Valles dome located near the headwaters of the river. Ranges of concentrations (minimum to maximum) for each site is shown.

Table S1. Mass of wood (e.g., pine spruce and aspen) samples for (a) oven drying and (b) burning procedure of wood samples.

Table S2. Detection limits for analyses using: a) inductively coupled plasma optical emission spectrometry (ICP-OES), and b) inductively coupled plasma mass spectrometry (ICP-MS)..... 38 Table S3. Maximum Contaminant Level (MCL) and different standards for exposure limits set by USEPA for $\mathrm{Cr}, \mathrm{Cu}, \mathrm{Fe}, \mathrm{Mn}$ and $\mathrm{Zn}$. Additionally, average concentrations of these 5 metals in natural soils (without known anthropogenic additions) are also provided for comparison with soil samples collected along the East Fork Jemez river ranges for this study.

Table S4. Acid extractable elemental content $\left(\mathrm{mg} \mathrm{kg}^{-1}\right)$ for wood samples (Pine, Spruce, Aspen) at $60^{\circ} \mathrm{C}, 350^{\circ} \mathrm{C}$ and $550^{\circ} \mathrm{C}$. Data are presented as Mean + standard deviation.

Table S5. The Kruskal Wallis test was used to determine if significant differences exist (defined as p-value < 0.05) between the tree species (Pine, Spruce, Aspen) at three temperatures $\left(60^{\circ} \mathrm{C}\right.$, $350^{\circ} \mathrm{C}$ and $550^{\circ} \mathrm{C}$ ) with respect to acid extractable metal concentrations ( $\log _{10}$ transformed). Individual contribution of the metals was not considered here due to limited number of observations $(n=3)$ for each metal. No significant difference (highlighted, $p$-value $=0.4007>$ 0.05) was observed for Pine, Aspen and Spruce at $60^{\circ} \mathrm{C}$. The limitation of Kruskal Wallis test is that it does not specify which specific sample is contributing to the overall difference. To address this, Mann Whitney U test was done to do pairwise comparisons between the samples.

Table S6. The Wilcoxon rank sum test (Mann-Whitney U test) was used to do pairwise comparisons ( $\mathrm{n}=9$ samples, ${ }^{9} \mathrm{C}_{2}=36$ combinations of pairs $)$ of tree species (Pine, Spruce, Aspen) at $60^{\circ} \mathrm{C}, 350^{\circ} \mathrm{C}$ and $550^{\circ} \mathrm{C}$ to test for significant differences (defined as $\mathrm{p}<0.05$ ) in metal concentrations ( $\log _{10}$ transformed). Individual contribution of the metals was not considered here due to limited number of observations $(n=3)$ for each metal.

Table S7. Specific surface areas $\left(\mathrm{m}^{2} / \mathrm{g}\right)$ of the Pine, Spruce and Aspen ash samples measured by Brunauer-Emmett-Teller (BET) method.

Table S8. Elemental composition $(\mathrm{C}, \mathrm{H}, \mathrm{N}, \mathrm{O})$ and ratios of Pine, Spruce and Aspen samples at $60^{\circ} \mathrm{C}, 350^{\circ} \mathrm{C}$ and $550^{\circ} \mathrm{C} . \mathrm{H} / \mathrm{C}$ is the atomic ratio of hydrogen to carbon; $\mathrm{O} / \mathrm{C}$ is the atomic ratio of oxygen to carbon and $(\mathrm{O}+\mathrm{N}) / \mathrm{C}$ is the atomic ratio of the sum of nitrogen and oxygen to carbon.

Table S9. Atomic content for the unreacted and reacted $350^{\circ} \mathrm{C}$ pine ash as determined by X-ray photoelectron spectroscopy (XPS) survey scan. 


\section{Chapter 1: Introduction}

The thesis has been divided into 3 chapters and an appendix. Chapter 2 provides a summary on the current state of scientific knowledge on the topic, which includes a background on impacts of wildfire ash on water chemistry, mechanisms affecting wood ash reactivity, ending with a review of research gaps and limitations in the proposed field of study. Chapter 3 is the main body of work of the thesis, formatted as a research paper which will be submitted to the peer-reviewed journal Environmental, Science \& Technology. The main topic covered in Chapter 3 relates to the investigation of metal reactivity in laboratory burned wood from a watershed affected by wildfire. The objective of the study presented in Chapter 3 was to investigate the interfacial processes affecting wood ash reactions with water by integrating laboratory experiments, spectroscopy, microscopy, and aqueous chemistry methods. This chapter also discusses the observed results with discussions providing mechanistic explanations and environmental implications of this study. The Appendix contains supplementary data obtained for the study presented in Chapter 3. 


\section{Chapter 2: Background and Literature Review}

\section{Background and Significance.}

Wildfires cause catastrophic damages to natural resources around the world every year. Large scale economic and societal impacts are often observed following a wildfire event. Post-fire adverse impacts on water quality often disrupt the drinking water supply for nearby communities. The effects of wildfires are particularly relevant in semi-arid regions of the world, such as the South-western region of the US, in which the combination of earlier spring snowmelt, decreased winter precipitation and greater vapor-pressure deficit in the warm season results in substantial water limitation stress on forests. ${ }^{1-4}$ Additionally, climate change has contributed to increased drought severity and frequency in the south-western US. ${ }^{5}$ The complex interactions between these factors, combined with uncontrolled urbanization and forest management practices (i.e. fire suppression by forest thinning), have contributed to increased level of wildfire activity. ${ }^{6}$

Wildfires can cause a wide range of effects on the nearby surface water quality. Post-fire storm events in burned watersheds can cause the transport of wood ash, debris and sediments into nearby streams which has detrimental impacts on water quality. Several post fire investigations have reported increased concentration of metals such as $\mathrm{Fe}, \mathrm{Pb}, \mathrm{Ni}, \mathrm{Zn}, \mathrm{Al}, \mathrm{As}, \mathrm{Cd}, \mathrm{Mn}$ and $\mathrm{Cu}$ in the watershed affected by increased loading of ash and sediments. ${ }^{7-10}$ The Valles Caldera National Preserve (VALL) in north central New Mexico is an example of a site with frequent wildfire activity in recent years. ${ }^{11}$ Two major wildfires have affected the VCNP watershed since 2011: (1) The Thompson Ridge wildfire burned 23,965 acres in VCNP in $2013^{12}$ and (2) The catastrophic Las Conchas, one of the largest in New Mexico history, which burned over 156000 acres of area in the Jemez Mountains in 2011. ${ }^{13}$ Post-fire runoff of debris and ash in the Rio Grande river, following thunderstorms over the burned area caused turbidity peaks of over 1000 NTU and sags 
in dissolved oxygen (DO) and $\mathrm{pH}^{14}$ The VCNP contains the headwaters of multiple streams including the East Fork Jemez River, ${ }^{15}$ a tributary of the Middle Rio Grande which serves as a drinking water source for nearby communities. The load of ash and debris forced temporary shutdowns of local water treatment plants in Albuquerque and Santa Fe. Post fire runoff effects like the one after the Las Conchas fire can cause transport of organic matter, metals and nutrients with debris and ash, which can significantly affect the quality of water supplied to nearby communities and agriculture. ${ }^{14,16,17}$

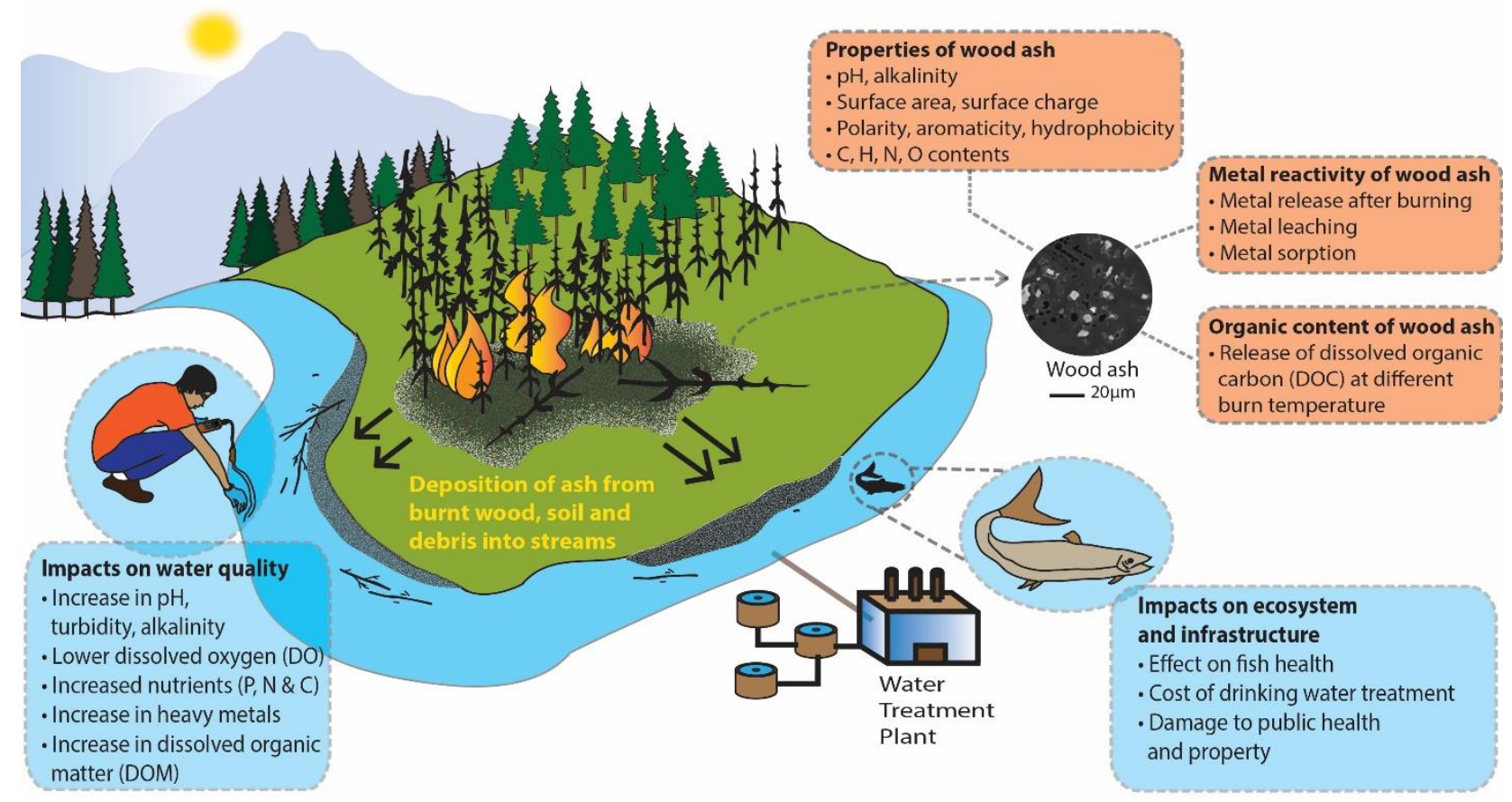

Figure 1: Relevant biogeochemical processes affected by wildfires in a watershed ecosystem.

Information on the composition and reactivity of metals associated with wood ash is important to better understand the potential impacts on water quality caused by wildfires. The following subsections will discuss in more detail, the minerology and chemical characteristics of wood ash, the effects of different burning temperatures on wood ash minerology and the current literature on reactivity of metals in wood ash and other similar materials like biochar. 


\section{Wildfire Ash and Water Chemistry.}

The current literature on wildfire impacts on water quality is focused heavily on suspended sediment, dissolved organic matter, and nutrients. The knowledge on the impacts of metals associated with ash and debris on water quality is still limited. Wildfire can transform fuel (i.e. biomass, wood, soil organic matter) into ash and other materials of different physical and chemical properties. ${ }^{18}$ Wood ash is derived from burned vegetation. Plants contain macro $(\mathrm{Ca}, \mathrm{K}, \mathrm{Mg})$ and micronutrients (Fe, Mn, Zn, $\mathrm{Cu}, \mathrm{Ni}$ ) essential for their growth. ${ }^{19}$ Composition and distribution of the nutrients in plants are mainly controlled by the surrounding soil composition and ecosystem changes. ${ }^{19-21}$ These nutrients become concentrated in the ash produced from burnt vegetation because of wildfire. ${ }^{22,23}$ The nutrients, trace elements and other inorganic and organic constituents in wood ash can accumulate in nearby surface water sources post-fire and impact water quality.

\subsection{Release of Metals.}

Previous studies have reported elevated concentrations of metals in watersheds due to the transport of ash after wildfire events. After the 2009 station fire in California, total concentrations of $\mathrm{As}, \mathrm{Pb}, \mathrm{Zn}$ and $\mathrm{Ni}$ were reported higher in the burned watersheds. ${ }^{10}$ Trace elements (e.g., Fe, $\mathrm{Mn}, \mathrm{Hg}$ ) from burned soil and ash were also found in elevated concentrations in nearby streams after the fire. ${ }^{10}$ Elevated concentrations of $\mathrm{As}, \mathrm{Al}, \mathrm{Cd}, \mathrm{Cr}, \mathrm{Fe}, \mathrm{Pb}, \mathrm{Hg}, \mathrm{Ca}, \mathrm{Mg}, \mathrm{Mn}, \mathrm{Ba}$ and $\mathrm{K}$ have also been observed in sediments and streamflows in fire-affected watersheds, several months after the fire events. ${ }^{7,24-27}$ A previous study by Ignatavicius et al. ${ }^{28}$ compared long term environmental data in Lithuanian rivers and correlated the increase of heavy metals such as $\mathrm{Cu}, \mathrm{Pb}$ and $\mathrm{Zn}$ to the occurrences of land fires. In New Mexico, the Cerro Grande fire in May 2000 burned over 7400 acres of mixed conifer forests in the Valles Caldera National Preserve (VALL) area near the Los Alamos National Laboratory (LANL), ${ }^{8}$ resulting in accumulation of ash and debris in the burned 
watershed. After the fire, runoff samples were collected from 40 sites and elevated concentrations of trace metals were found in some samples. For example, elevated concentrations of total $\mathrm{Cu}(610$ $\left.\mu \mathrm{g} \mathrm{L}{ }^{-1}\right)$ and total $\mathrm{Cr}\left(510 \mu \mathrm{g} \mathrm{L}^{-1}\right)$ were measured in post fire runoff water samples collected from the burned watersheds near Guaje Canyon, close to the Los Alamos National Laboratory. ${ }^{8}$ Reports from these post-fire investigations show that concentrations of trace metals in water and soil near a burned watershed can increase from the addition of ash and debris by storm water runoff.

\subsection{Release of Nutrients.}

Wildfires can release high concentrations of nutrients that can significantly impact the water quality. The primary nutrients of concerns after a wildfire are Phosphorus $(\mathrm{P})$, Nitrogen $(\mathrm{N})$ and Carbon (C). A previous by study by Uldis et. al. ${ }^{29}$ investigated $\mathrm{P}$ availability in post-fire watersheds and found that $\mathrm{P}$ concentration were 2 to 13 times higher in burned watersheds than in unburned watersheds. Higher availability of $\mathrm{P}$ in burned watersheds can facilitate strong algal productivity and shifts in ecological responses. ${ }^{29}$ Phosphate, Nitrate and Ammonium concentrations above 5 to 60 fold over background levels were measured in fire affected streams in Glacier National park. ${ }^{30}$ In New Mexico, post fire runoff caused transport of organic matter and nutrients $\left(6 \times\right.$ background levels for $\mathrm{NO}_{3}-\mathrm{N}$ and $100 \times$ background levels for $\left.\mathrm{PO}_{4}\right)$ with debris and ash in the VALL, which significantly affected the quality of water supplied to nearby

communities. ${ }^{14,16}$ Slow recovery of nutrient concentrations leads to long term nutrient availability in the fire affected sites and leaching of nutrients into soil. Another important and widespread water quality issue called eutrophication, is caused by high concentrations of nutrients such as $\mathrm{P}$ and $\mathrm{N}$ in surface water sources. High $\mathrm{P}$ and $\mathrm{N}$ in water can lead to the growth of algal blooms, which are toxic and can increase fish kills and reduce water quality. ${ }^{31}$ 


\subsection{Elevated levels of Dissolved Organic Carbon (DOC) and Disinfection Byproducts (DBPs).}

After a wildfire event, elevated levels of dissolved organic matter (DOM), generally measured as DOC, in downstream of nearby water sources has been associated to heavy loads of ash and debris by several previous studies. ${ }^{18,26,32}$ Recent studies have linked water extractable organic matter (WEOM) from burned soil ${ }^{17,33}$ and ash ${ }^{34}$ to the formation of disinfection byproducts (DBPs) ${ }^{35,36}$ DBPs are of particular concern due to their effect on public health, which includes risks of bladder cancer and disruption in cell growth. ${ }^{37,38}$ Two types of DBPs that are of interest are Carbonaceous DBPs (C-DBPs) and Nitrogenous DBPs (N-DBPs). Commonly studied C-DBPs include trihalomethanes (THM) and haloacetic acids (HAA), while N-DBPs such as haloacetonitriles (HAN) and halonitromethanes (e.g., chloropicrin) are also of interest. These species have been observed to form in solution of laboratory burned soil and ash following addition of chlorine..$^{33,39}$

\subsection{Change in water quality parameters (pH, DO, turbidity).}

Water quality degradation after a wildfire is a commonly observed phenomenon. A previous study by C. N. Dahm et al. ${ }^{14}$ measured continuous water quality data in the middle Rio Grande and found marked changes in $\mathrm{pH}$, dissolved oxygen (DO) and turbidity over a period of two months after the Las Conchas fire. Turbidity peaks of up to 2500 NTU, pH sags (up to 0.75 units) and DO sags (as low as $0 \mathrm{mg} \mathrm{L}^{-1}$ ) were observed as a result of heavy loadings of ash, debris

and sediments. ${ }^{14}$ Sherson L. R. et. al. ${ }^{16}$ observed similar effects of DO and $\mathrm{pH}$ sags in the East Fork Jemez river after the Las Conchas fire. The transport of ash and nutrient often changes the water quality downstream, although it is difficult to quantify the different contributions of ash, sediments and nutrients to the changes in water quality. The change in water quality parameters 
caused by ash, sediment and nutrients affects the treatability of source water to be used for drinking purposes and has become a matter of particular concern for many local water authorities. ${ }^{17,25}$

\section{Characteristics of wood ash at different burn intensity and severity.}

The terminologies 'burn intensity' and 'burn severity' has specific usages in literature related to wildfires. ${ }^{40}$ Fire intensity has been related to the energy released during different phases of a fire which is dependent on several factors such as reaction intensity, fireline intensity, temperature, heating duration and radiant energy. ${ }^{40}$ The term 'burn severity' is generally associated with the loss of organic matter and conversion of organic matter to ash. ${ }^{40}$ The effects of burn severity and burn severity can have a wide range of impacts on ash properties, specifically on the concentration of nutrients and other major and minor elements present in the ash. These effects can also be used to understand the availability and impacts of wildfire ash on the surrounding soil and water quality post-fire. The following subsections discuss, in detail, the effects of different burn intensity and severity on ash properties.

\subsection{Physical and hydrological properties of ash.}

The effect of burn severity on ash is evident in different responses observed in physical properties such as color, mass, particle size, hydraulic conductivity and water storage capacity. The color of ash goes from darker shades of brown to lighter shades of gray and white as burning temperature increases. ${ }^{18,41}$ Although the rate of mass loss can vary dependent on the particular tree species being considered, generally the percentage of mass loss increases with higher temperature. ${ }^{41}$ In a previous study, Bodi et. al. observed finer ash particle size with increasing temperature between $350^{\circ} \mathrm{C}$ to $700^{\circ} \mathrm{C} .{ }^{18}$ The hydraulic conductivity and water storage capacity of ash can also vary significantly depending on the burning temperature. Post-fire watersheds are often covered with a layer of ash that affect the infiltration of water after storm events. Several 
post-fire investigations have reported increased infiltration and water repellency behavior of ashcovered soil in the burned watersheds. ${ }^{18,42,43}$ However, this behavior is difficult to correlate with properties like hydraulic conductivity and temperature difference due to the highly variable nature of fuel and burning conditions. Further studies linking the hydraulic properties of ash with water repellency behavior is necessary.

\subsection{Chemical and mineralogical properties of ash.}

Ash can contain both organic and inorganic constituents depending on the combustion temperature. Bodi et. al. ${ }^{18}$ has reported previously that at low burning temperature of below $4500^{\circ} \mathrm{C}$, organic constituents are likely to be present in higher amount. Dlapa et. al found that the loss of organic matter in ash with increasing temperature leads to significant decrease of hydrophobic surfaces in ash. The loss of hydrophobicity in ash has important implications in terms of post-fire runoff events. The inorganic constituents consist of a range of macro and micro elements. The macro elements such as $\mathrm{Ca}, \mathrm{K}$ and $\mathrm{Mg}$ are abundant across all tree species. ${ }^{19}$ Micro elements include a range of elements such as $\mathrm{As}, \mathrm{Al}, \mathrm{Cd}, \mathrm{Cr}, \mathrm{Fe}, \mathrm{Pb}, \mathrm{Hg}, \mathrm{Mn}, \mathrm{Zn}, \mathrm{Si}$ etc. Mineralogical composition of wood ash likely consists of carbonates and oxide phases of different metals. ${ }^{23}$ The dissolution of these carbonate and oxide phases in reaction of ash with water can cause rapid $\mathrm{pH}$ increase in solution. ${ }^{23,44}$

\subsection{Effects of temperature on ash chemical and mineralogical properties.}

Temperature is a particularly important factor that affects the elemental composition of wood ash. ${ }^{18,45,46}$ Wildfires can have a wide temperature range from $200^{\circ} \mathrm{C}$ to $1200^{\circ} \mathrm{C} . .^{47-49}$ Depending on the combustion temperature, ash can contain a range of inorganic minerals, nutrients, heavy metals, trace elements, and organic substances. ${ }^{18,22,50}$ At temperatures lower than $450^{\circ} \mathrm{C}^{18,50}$ ash is likely to contain higher levels of organic substances than at temperatures higher 
than $450^{\circ} \mathrm{C}$, where most of the organic carbon is volatilized. ${ }^{18,50}$ Similar results have been reported in experiments with burned soil samples. ${ }^{33}$ The increase in burning temperature has varying effects on the elements present in wood ash. Previously L. Etiégni et. al. ${ }^{51}$ observed that K, Na, Zn and $\mathrm{CO}_{3}$ content decreases with increasing burning temperature from $538^{\circ} \mathrm{C}$ to $1093^{\circ} \mathrm{C}$ but other metals tend to remain constant or increase. The amount of ash yield after burning can also vary depending on the type of tree species and burn temperature. Increase in burn severity can result in the increase of $\mathrm{CaCO}_{3}$ and $\mathrm{pH}$ of ash, as observed in previous field investigations. ${ }^{41,52}$ Increase in the loss of total carbon (TC) and total nitrogen (TN) is observed with increasing burn temperature. ${ }^{52}$ The loss of TC and TN contribute significantly to the total mass loss of ash at higher temperatures. ${ }^{46}$

\section{Mechanisms Affecting Wood Ash Reactivity.}

Recent studies have linked water extractable organic matter (WEOM) from burned soil ${ }^{17,33}$ and $\operatorname{ash}^{34}$ to the formation of disinfection byproducts (DBPs) ${ }^{35,36}$.The alteration of DOM with increasing temperature from Ponderosa Pine ash has been studied previously by Wang et al. ${ }^{39}$ and they observed decreased reactivity of the ash in forming DBPs such as trihalomethane (THM) and chloral hydrate (CHD) with increasing temperature from $50^{\circ} \mathrm{C}$ to $400^{\circ} \mathrm{C}$. The DOM loss at higher temperatures for ash in this study is comparable to that observed in laboratory heated soil reported in a previous study by Cawley et $\mathrm{al}^{33}$. Thus, the temperature dependent variability for both ash and soil can have implications in terms of variable loading of DOM and DBP precursors from different burn conditions associated with wildfires and prescribed fires, as suggested by previous studies ${ }^{33,39}$

More insights into the mechanisms of metal mobilization by wood ash can be found from literatures relating metal mobilization to biochar, a material similar to wood ash in composition ${ }^{53,54}$ and is increasingly applied in environmental remediation as a natural sorbent for organic and inorganic contaminants ${ }^{55-57}$. Previous studies have reported $\mathrm{Cu}(\mathrm{II})$ sorption to organic functional 
groups of biochar in water at $\mathrm{pH}$, while at $\mathrm{pH} 7$ to 9, carbonate phases like azurite $\left(\mathrm{Cu}_{3}\left(\mathrm{CO}_{3}\right)_{2}(\mathrm{OH})_{2}\right)$ and oxide phases like tenorite $(\mathrm{CuO})$ precipitated within the biochar $^{58}$. Adsorption between $\mathrm{Cu}^{2+}$ and negatively charged biochar was reported as the prevailing mechanism of $\mathrm{Cu}$ immobilization in soil ${ }^{57,59}$. Biochar has also been proven effective in immobilizing positively charged $\mathrm{Cd}$ and $\mathrm{Zn}$ in water at $\mathrm{pH} 6$ to $8^{60}$. Conversely, enhanced mobility of oxyanions like $\mathrm{As}^{61,62}$ and $\mathrm{Sb}^{63}$ were found in biochar treated soil. The effectiveness of biochar in $\mathrm{Cr}(\mathrm{VI})$ immobilization is significantly reduced at $\mathrm{pH} 5$ and above, both in soil ${ }^{64}$ and water ${ }^{65,66}$.

Carbon-based materials like ash and biochar contain negatively charged surface functional groups that contribute to the sorption of heavy metals. The analysis of light elements such as $\mathrm{C}$, $\mathrm{N}, \mathrm{O}$ and $\mathrm{H}$ and molar ratios of these elements can indicate changes of properties in the material. For example, higher degree of aromaticity and lower degree of hydrophilicity is associated with increasing burn temperatures for biochar. ${ }^{67,68}$ Oxygen containing functional groups (e.g., -C=O, and $-\mathrm{COOH}$ ) can act as dominant binding sites. The surface charge of biochar is increasingly negative and the surface area increases with higher burning temperature, suggested by previous studies. ${ }^{67,69}$

Wood ash, like biochar has applications to agriculture and forestry. The high alkalinity of wood ash is useful for treatment of acidic soil generally found in tropical forests. The application of wood ash to plants can be beneficial for the growth of the plants because of increase in the concentration of macro elements $(\mathrm{Ca}, \mathrm{K}, \mathrm{Mg})$ and $\mathrm{P}$ and decrease in trace metal $(\mathrm{Cd}, \mathrm{Cu}, \mathrm{Cr}, \mathrm{Mn}$, $\mathrm{Ni}, \mathrm{Pb}, \mathrm{Zn}$ ) concentration. Previously, Etiegni et al. ${ }^{70}$ observed that, wood ash, if used in levels of $2 \%$ or lower, can work as an effective fertilizer and liming agent. However, repeated and longterm application of wood ash can cause leaching of trace metals into soils, as suggested by previous 
studies. ${ }^{53,71}$ More studies are necessary to better understand the mechanisms affecting adsorption, precipitation, and dissolution reactions facilitated by wood ash that affect metal mobility.

\section{Research Gaps.}

While other studies have characterized metals in wood ash, ${ }^{22,23,72}$ the specific mechanisms affecting metal mobilization by ash remain poorly understood. Most of the existing literature on wildfire impacts has focused on the effects of nutrients and dissolved organic carbon on water quality parameters such as $\mathrm{pH}$, turbidity, DO and DBP potential. ${ }^{14,17,25,34,73}$ The release of metals from wood ash and debris has been reported in a number of post-fire investigations. ${ }^{7,9,10,74}$ Previous studies have reported the presence of $\mathrm{Ca}, \mathrm{Mg}, \mathrm{Al}, \mathrm{Fe}$ and $\mathrm{Mn}$ as metal bearing carbonate and oxide phases in wood ash burned at $550^{\circ} \mathrm{C} .^{23,46}$ These metal bearing phases are easily dissolvable in reaction of ash with water, resulting in rapid and significant increase in solution $\mathrm{pH} \cdot{ }^{22,23}$ However, the adsorptive capacity of the carbonate phases in ash often contribute to the re-adsorption of metals from solution to ash. ${ }^{23}$ Burning of organic matter often results in the presence of negatively charged functional groups (i.e. $\mathrm{C}=\mathrm{O},-\mathrm{COOH}$ ) in ash. These functional groups attract positively charged cationic metals, therefore contributing to metal uptake from solution. The ash-metal interaction in solution is also highly dependent on $\mathrm{pH}$. For example, at an environmentally relevant $\mathrm{pH}$ range of 6 to 8 , metals that act as Lewis acid in solution, such as $\mathrm{Cu}(\mathrm{II})$, exhibit positive charge. However, at $\mathrm{pH}$ of 6 to 8 , metals such as $\mathrm{Cr}(\mathrm{VI})$ are known to exist in solution as negatively charged soluble forms of $\mathrm{CrO}_{4}{ }^{2-}, \mathrm{HCrO}_{4}{ }^{-}$and $\mathrm{Cr}_{2} \mathrm{O}_{7}{ }^{2-}$. This reversal of charges causes selective adsorption of metal ions from solution by ash. All of these processes play a key role in mobilization of metals by ash after a wildfire. This is why, the investigation of these interfacial processes in reaction of wood ash and water is necessary to facilitate better understanding of post fire metal mobilization. Additionally, the effects of different burn temperatures on the properties and 
reactivity of wood ash is necessary to better understand metal and DOC leaching from ash. The investigation presented in this thesis attempts to address these knowledge gaps. 


\title{
Chapter 3:
}

\section{Metal Reactivity in Laboratory Burned Wood from a Watershed Affected by Wildfires}

\author{
Asifur Rahman ${ }^{1}$, Eliane El Hayek ${ }^{2}$ Johanna M. Blake$^{3}$, Rebecca J. Bixby ${ }^{4}$, Abdul-Mehdi Ali ${ }^{5}$, \\ Michael Spilde ${ }^{5}$, Amanda A. Otieno ${ }^{6}$, Keely Miltenberger ${ }^{5}$, Cyrena Ridgeway $^{7}$, Kateryna \\ Artyushkova $^{8}$, Viorel Atudorei $^{5}$, José M. Cerrato $^{1^{*}}$ \\ *Corresponding email address: jcerrato@unm.edu
}

Telephone: (001) (505) 277-0870

Fax: (001) (505) 277-1988

${ }^{1}$ Department of Civil Engineering, MSC01 1070, University of New Mexico, Albuquerque, New Mexico 87131, USA

2 Department of Chemistry, MSC03 2060, University of New Mexico, Albuquerque, New Mexico 87131, USA

${ }^{3}$ U.S. Geological Survey, 6700 Edith Blvd. NE Albuquerque New Mexico 87113, USA

${ }^{4}$ Department of Biology and Museum of Southwestern Biology, MSC03 2020, University of New Mexico, Albuquerque, New Mexico 87131, USA

${ }^{5}$ Department of Earth and Planetary Sciences, MSC03 2040, University of New Mexico, Albuquerque, New Mexico 87131, USA

${ }^{6}$ Water Resources Program, MSC05 3110, University of New Mexico, Albuquerque, New Mexico 87131, USA

${ }^{7}$ Department of Civil Engineering, New Mexico State University, Las Cruces, 88001, USA

${ }^{8}$ Department of Chemical and Biological Engineering, MSC01 1120, University of New Mexico, Albuquerque, New Mexico 87131, USA 
ABSTRACT: We investigated interfacial processes affecting metal mobility by wood ash under laboratory-controlled conditions using aqueous chemistry, microscopy and spectroscopy. The Valles Caldera National Preserve in New Mexico experiences severe catastrophic wildfires of devastating effects. Wood samples of Ponderosa Pine, Colorado Blue Spruce and Quaking Aspen, collected from this site were exposed to temperatures of $60^{\circ} \mathrm{C}, 350^{\circ} \mathrm{C}$ and $550^{\circ} \mathrm{C}$. The $350^{\circ} \mathrm{C}$ Pine ash had the highest content of $\mathrm{Cu}(4997+262 \mathrm{mg} \mathrm{kg}-1), \mathrm{Cr}(543+124 \mathrm{mg} \mathrm{kg}-1)$, and labile dissolved organic carbon (DOC, $11.3+0.28 \mathrm{mg} \mathrm{L}-1)$. Sorption experiments were conducted by reacting $350^{\circ} \mathrm{C}$ Pine, Spruce and Aspen ashes separately with $10 \mu \mathrm{M} \mathrm{Cu}(\mathrm{II})$ and $\mathrm{Cr}(\mathrm{VI})$ solutions. Up to $94 \%$ decrease in $\mathrm{Cu}(\mathrm{II})$ concentration was observed in solution while $\mathrm{Cr}(\mathrm{VI})$ concentration showed limited decrease (up to 13\%) after 180 mins of reaction. X-ray photoelectron spectroscopy (XPS) analyses detected increased association of $\mathrm{Cu}(\mathrm{II})$ on the near surface region of the reacted $350^{\circ} \mathrm{C}$ Pine ash from the sorption experiments compared to the unreacted ash. The results suggest that dissolution and sorption processes should be considered to better understand the potential effects of metals transported by wood ash on water quality that have important implications for post-fire recovery and response strategies. 
TOC Art.

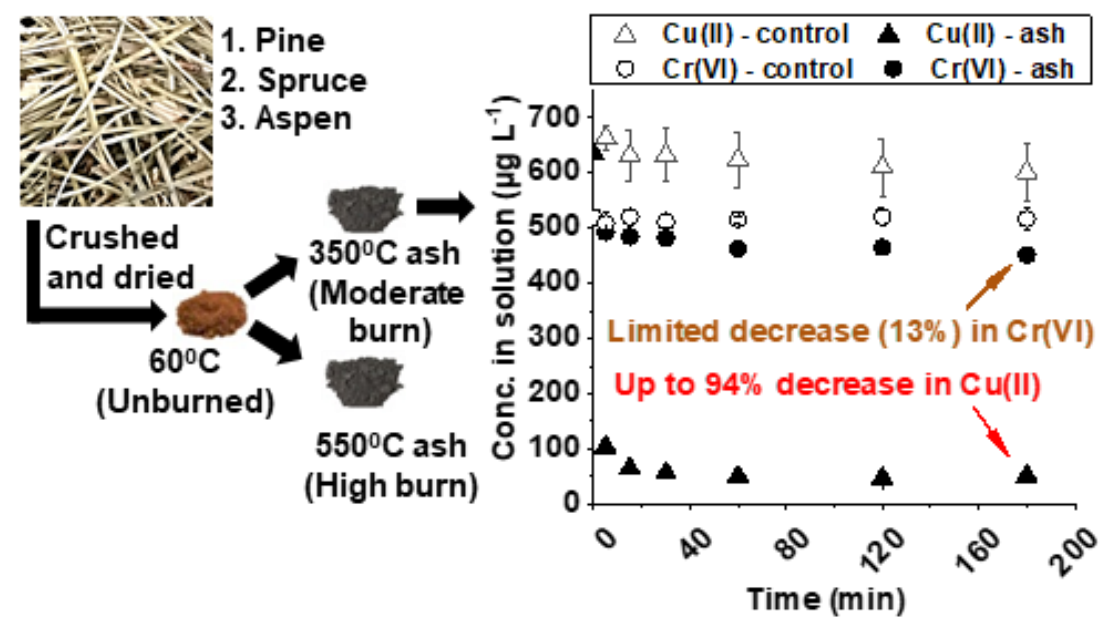

Figure 2: TOC figure showing the process from laboratory burning to metal sorption experiments. 


\section{Introduction}

Post-fire storm events in watersheds can cause the transport of wood ash into nearby streams which has detrimental impacts on water quality. In the United States, the forests in the south-western regions have seen increased occurrences of large intensity wildfires because of worldwide effects of climate change. ${ }^{24,75,76}$ The Valles Caldera National Preserve (VALL) in north central New Mexico is an example of a site with frequent wildfire activity in recent years. ${ }^{11}$ For example, the following two major wildfires have affected the VALL watershed since 2011: (1) The Thompson Ridge wildfire burned 23,965 acres in VALL in $2013^{12}$ and (2) The catastrophic Las Conchas, one of the largest in New Mexico history, which burned over 156,000 acres of area in the Jemez Mountains in 2011. ${ }^{13}$ Post-fire runoff of debris and ash in the Rio Grande river, following thunderstorms over the burned area caused turbidity peaks of over 1000 NTU, sags in dissolved oxygen (DO) and fluctuations in $\mathrm{pH}$ (7.5 to 9). ${ }^{14}$ Total concentrations of $\mathrm{Al}$ and $\mathrm{Cu}$ in the Rio Grande following the Las Conchas fire were above aquatic life criterion for both metals. ${ }^{77}$ Additionally, post fire runoff caused transport of organic matter and nutrients $(6 \times$ background levels for $\mathrm{NO}_{3}-\mathrm{N}$ and $100 \times$ background levels for $\mathrm{PO}_{4}$ ) with debris and ash in the VALL, which significantly affected the quality of water supplied to nearby communities. ${ }^{14,16}$ Information on the composition and reactivity of metals associated with wood ash is important to better understand the potential impacts on water quality.

While previous studies have characterized metals and organic matter in ash and soil, $^{22,23,33,72}$ the specific mechanisms controlling post-fire metal mobilization remain poorly understood. Elevated concentrations of metals have been observed in sediments and surface water in fire-affected watersheds, for several months after the fire events. ${ }^{7,24-27}$ Recent studies have linked water extractable organic matter (WEOM) from burned soil ${ }^{17,33}$ and $\operatorname{ash}^{34}$ to the formation 
of disinfection byproducts (DBPs). ${ }^{35,36}$ Temperature is a particularly important factor that affects the elemental composition and mineralogy of wood ash. ${ }^{18,45,46}$ For example, a previous study from our group identified the presence of $\mathrm{Ca}, \mathrm{Mg}, \mathrm{Al}, \mathrm{Fe}$ and $\mathrm{Mn}$ as metal bearing carbonate and oxide phases in wood ash burned at $550^{\circ} \mathrm{C} .{ }^{23}$ Results from laboratory batch experiments suggested that these metal-bearing phases are readily water soluble, but the re-adsorption of these metals to ash can occur in later times of the experiments. ${ }^{23}$ Although this study provides valuable insights into the presence of metal bearing phases in ash and their potential effects on metal re-adsorption, the knowledge on the specific processes affecting metal dissolution and sorption in wood ash is still limited.

More mechanistic investigations have been reported in the literature related to reactivity of biochar, a material similar to wood ash in composition. ${ }^{53,54}$ Biochar is a natural sorbent and is increasingly applied in environmental remediation of organic and inorganic contaminants. ${ }^{55-57}$ The sorption of $\mathrm{Cu}$ (II) to organic functional groups of biochar in water can occur at $\mathrm{pH}$ below $7 .{ }^{58}$ However, $\mathrm{Cu}$-associated phases like azurite $\left(\mathrm{Cu}_{3}\left(\mathrm{CO}_{3}\right)_{2}(\mathrm{OH})_{2}\right)$ and tenorite $(\mathrm{CuO})$ precipitate within the biochar surface at $\mathrm{pH}$ higher than $7 .{ }^{58}$ Sorption between positively charged ions and negatively charged biochar is an effective mechanism for immobilizing metals in soil..$^{57,59,60}$ The immobilization of $\mathrm{Cr}(\mathrm{VI})$ through biochar sorption is significantly reduced at $\mathrm{pH} 5$ and above. ${ }^{64}$, ${ }^{65,66}$ Enhanced mobility of oxyanions like $\mathrm{As}^{61,62}$ and $\mathrm{Sb}^{63}$ has been observed in biochar-treated soil. Similar mechanistic studies are necessary to better understand sorption, precipitation, and dissolution reactions facilitated by wood ash that can affect post fire metal mobility.

The main objective of this study is to investigate the interfacial processes affecting wood ash reactions with water by integrating laboratory experiments, spectroscopy, microscopy, and aqueous chemistry methods. Soil and surface water chemistry from burned areas of VALL provide 
environmental context for the study. The release of metals and dissolved organic carbon (DOC) was assessed in batch experiments reacting laboratory burned wood ash with water. Additional experiments were conducted to investigate sorption processes that affect ash-metal interactions. The focus of this study is to identify interfacial physical-chemical processes that have not been extensively studied in the existing wildfire literature. The results from this investigation have relevant implications for the improvement of post-fire response in affected watersheds.

\section{Materials and Methods}

Field Sampling and Ash Preparation. The East Fork Jemez River and the adjacent area were affected by the Las Conchas and Thompson Ridge wildfires in the past. There is a lack of information about metals in soils, water and wood from the VALL. Water and soil sampling were done to assess the current availability of metals in this fire affected watershed. Wood was collected from an unburned area to experiment with laboratory burn temperatures. Additional details about sampling methods are provided in the SI. The description and co-ordinates of the sampling sites in Valles Caldera for wood, water and soil samples are shown in Figure S1. The vegetation in the VALL is dominated by different species of Pine, Spruce, Aspen, and Oak. ${ }^{78}$ Wood samples of Ponderosa Pine, Colorado Blue Spruce and Quaking Aspen were collected from higher elevation mixed coniferous forest areas which have a fire disturbance history from Las Conchas and other fires. $^{23,79}$ This area in VALL is also densely forested which undergoes prescribed burns periodically and account for approximately $25 \%$ of the precipitation volume in the Caldera. ${ }^{80}$ From this point on, we will call these tree species simply Pine, Spruce, and Aspen. The collected wood samples were crushed using a wood chipper (Sun Joe CJ601E). The crushed samples were ground to fine powders using a Powdertec 3090 sample mill and then oven dried at $60^{\circ} \mathrm{C}$ for $48 \mathrm{~h}$ before burning. The ground and dried samples for each tree were mixed together in a container to 
homogenize the samples before burning. The homogenized samples were burned in a laboratory muffle furnace at $350^{\circ} \mathrm{C}$ (moderate burn) and at $550^{\circ} \mathrm{C}$ (high burn) for 4 hours to prepare ash. Table S1 contains data on mass of samples before and after burning.

Acid Digestion and Solution Chemistry Analyses. Wood samples were acid digested in triplicates $(\mathrm{n}=3)$ at $95^{\circ} \mathrm{C}$ for 4 hours using Aqua Regia [2 $\mathrm{mL} \mathrm{HNO}_{3}(67-70 \%)+6 \mathrm{~mL} \mathrm{HCl} \mathrm{(34-}$ $37 \%$ ), trace metal grade]. Following heating, acid extracts were diluted with $18 \mathrm{M} \Omega$ water to 50 $\mathrm{mL}$. Processing of all aqueous samples (water, soil and wood) for this study was done by filtering through a $0.45 \mu \mathrm{m}$ filter, acidifying with $2 \% \mathrm{HNO}_{3}$ and refrigerating at $4{ }^{\circ} \mathrm{C}$ until further solution chemistry analyses. Inductively Coupled Plasma-Optical Emission Spectrometry (ICP-OES, PerkinElmer Optima 5300DV) was used for detection of concentrations of major elements (Ca, $\mathrm{Mg}$ and $\mathrm{K})$. Minor or trace elements were analyzed using Inductively Coupled Plasma-Mass Spectrometry (ICP-MS, PerkinElmer NexION 300D). Both the ICP-OES and ICP-MS analyzed an internal indium standard and were calibrated using a 5-point calibration curve. The quality of the results was ensured with proper quality control and quality assurance standards. The detection limits for the ICP-OES and ICP-MS for specific elements are shown in Table S2. The DOC in these samples was measured using a Tekmar-Dohrmann Phoenix 8000 TOC Analyzer.

Batch Experiments for DOC concentration and metal dissolution. For DOC dissolution experiments, batch reactors were operated in triplicates by reacting $0.1 \mathrm{~g}$ sample of $60^{\circ} \mathrm{C}, 350^{\circ} \mathrm{C}$ and $550^{\circ} \mathrm{C}$ Pine, Spruce and Aspen samples with $30 \mathrm{~mL}$ of $18 \mathrm{M} \Omega$ deionized water. Replicates $(n=3)$ were sampled at $0,4,24$ and $72 \mathrm{hrs}$ and were analyzed using a Tekmar-Dohrmann Phoenix 8000 TOC Analyzer, following 5310-C persulfate-ultraviolet (UV) method. ${ }^{81}$ For metal dissolution experiments, $0.1 \mathrm{~g}$ samples of $350^{\circ} \mathrm{C}$ and $550^{\circ} \mathrm{C}$ Pine ash were reacted with $30 \mathrm{~mL}$ of 
$18 \mathrm{~m} \Omega$ water. Samples were collected at $0,4,24$ and 72 hours, centrifuged at $3000 \mathrm{rpm}(1660 \times \mathrm{g})$ for 15 mins and processed for further ICP analyses.

Batch sorption experiments of $\mathrm{Cu}(\mathrm{II})$ and $\mathrm{Cr}(\mathrm{VI})$ onto $350^{\circ} \mathrm{C}$ Ash. Batch sorption experiments in triplicates were conducted to investigate the effect of $350^{\circ}$ Pine, Spruce and Aspen ashes on mobilization of $\mathrm{Cu}(\mathrm{II})$ and $\mathrm{Cr}(\mathrm{VI})$ in water. We selected $\mathrm{Cu}(\mathrm{II})$ and $\mathrm{Cr}(\mathrm{VI})$ as examples of a cation that acts as a Lewis Acid (e.g. $\mathrm{Cu}$ ) and an oxyanion (e.g., $\mathrm{CrO}_{4}{ }^{2-}$ ) that could negatively impact surface waters. Additionally, elevated concentrations of these metals were found in surface water following wildfire events near VALL. ${ }^{8,77}$ Before the sorption experiments, ash samples were characterized by measuring Brunauer-Emmett-Teller (BET) specific surface area, zeta potential and $\mathrm{C}, \mathrm{H}, \mathrm{N}, \mathrm{O}$ elemental contents (wt \%). Detailed descriptions of these methods are in the supporting information (SI). For the sorption experiments, stock solutions (1000 ppm) of Cr(IV) and $\mathrm{Cu}$ (II) were prepared by dissolving analytical grade ( $>99 \%$ purity) $\mathrm{K}_{2} \mathrm{Cr}_{2} \mathrm{O}_{7}$ and $\mathrm{CuCl}_{2} .2 \mathrm{H}_{2} \mathrm{O}$ in $18 \mathrm{M} \Omega$ water. For the experiment, $0.1 \mathrm{~g}$ sample of $350^{\circ} \mathrm{C}$ Pine, Spruce and Aspen ashes was reacted separately with $10 \mu \mathrm{M}$ of $\mathrm{Cu}(\mathrm{II})$ and $\mathrm{Cr}(\mathrm{VI})$ stock solutions mixed in $50 \mathrm{~mL}$ of $18 \mathrm{M} \Omega$ water. The concentrations of $\mathrm{Cu}(\mathrm{II})$ and $\mathrm{Cr}(\mathrm{VI})$ were chosen to reflect maximum levels measured in water samples collected during storm events after the Cerro Grande fire. ${ }^{8}$ The $\mathrm{pH}$ was adjusted to $7.0 \pm 0.2$ using $2 \% \mathrm{HCl}$. Control experiments were done at $\mathrm{pH} 7.0 \pm 0.2$ for $\mathrm{Cu}(\mathrm{II})$ and $\mathrm{Cr}(\mathrm{VI})$. Samples were collected at 0, 4, 24 and 72 hours, centrifuged at $6000 \mathrm{rpm}(6640 \times \mathrm{g})$ for 3 mins and were processed for further solution chemistry analyses using ICP-MS.

Solid Phase Analyses. (SEM/EDX, EPMA, XRD, XPS). Solid phase analyses were performed on the unreacted and reacted $350^{\circ} \mathrm{C}$ Pine ash from the batch sorption experiments applying X-ray photoelectron spectroscopy (XPS), scanning electron microscopy coupled to energy dispersive X- 
ray spectroscopy (SEM/EDX), electron probe microanalysis (EPMA) and X-ray diffraction (XRD). Additional descriptions of these methods are in the supporting information (SI).

Statistical Analysis. Univariate data analysis were performed using the statistical software R. ${ }^{82}$ The statistical package in OriginPro ${ }^{83}$ was used for Principal Component Analysis (PCA). Due to the non-normality of the data, nonparametric tests for differences in acid extractable metal concentrations ( $\log _{10}$ transformed to reduce skewness in distribution) were performed to differentiate among 3 tree species (Pine, Spruce, Aspen) and among 3 temperatures $\left(60^{\circ} \mathrm{C}, 350^{\circ} \mathrm{C}\right.$ and $550^{\circ} \mathrm{C}$ ). Kruskal-Wallis test was performed to determine if the tree species and the temperatures differ significantly (defined as $p<0.05)$ with respect to metal concentrations $\left(\log _{10}\right.$ transformed). Wilcoxon rank sum test was used to do pairwise comparisons of all the samples to test for significant differences between tree species and temperatures (defined as $p<0.05$ ). PCA was performed to better understand the correlations among ash samples in triplicates with respect to acid extractable metal (Al, Ca, Cr, Cu, Fe, K, Mg, Mn, Ni, Si, Sr, Zn) concentrations for all tree species.

\section{Results and Discussion}

Water Quality and Sediment Data from Valles Caldera. The presence of $\mathrm{Cu}, \mathrm{Cr}, \mathrm{Fe}, \mathrm{Zn}$, and Mn was observed in water from the wildfire affected East Fork Jemez River and in soils exposed to varying burn severities upslope from the East Fork Jemez River headwaters (Table 1). Maximum total concentrations of $\mathrm{Cu}\left(37.4 \mu \mathrm{g} \mathrm{\textrm {L } ^ { - 1 }}\right)$ and $\mathrm{Fe}\left(2650 \mu \mathrm{g} \mathrm{L}^{-1}\right)$ in the water samples collected from site 2 and $\mathrm{Zn}\left(352 \mu \mathrm{g} \mathrm{L}^{-1}\right)$, from site 3 were above the USEPA standards for acute or chronic exposure values for aquatic life in freshwater (Tables 1 and S3). Total Cr $\left(105 \mu \mathrm{g} \mathrm{L}^{-1}\right)$ in the water samples collected from site 1 exceeded the USEPA standards for acute or chronic exposure for both $\mathrm{Cr}(\mathrm{III})\left(74 \mu \mathrm{g} \mathrm{L}^{-1}\right)$ and $\mathrm{Cr}(\mathrm{VI})\left(11 \mu \mathrm{g} \mathrm{L}^{-1}\right)$. In a 2001 study by the New Mexico 
Environment Department, Al, pH, DO, and turbidity in the East Fork Jemez river were listed as exceeding the Total Maximum Daily Load, while metals, such as $\mathrm{Cu}, \mathrm{Cr}$ and $\mathrm{Zn}$ were found to be below detection limit, ${ }^{84,85}$ lower than found in this study. Average concentrations of major and trace elements $\left(\mathrm{mg} \mathrm{kg}^{-1}\right)$ in non-anthropogenically affected soils in the US estimated by Burt et al. ${ }^{86}$ (Table S3) were used to evaluate the metal concentrations in the soil samples collected along the river ranges. Iron $(\mathrm{Fe})$ was the most abundant metal with concentrations ranging from 4980 $\mathrm{mg} \mathrm{kg}^{-1}$ to $9850 \mathrm{mg} \mathrm{kg}^{-1}$. Copper $(\mathrm{Cu})$ concentration in the collected soil samples from sites $\mathrm{V} 1$, $\mathrm{V} 2$ and $\mathrm{V} 3$ ranges from $44.2 \mathrm{mg} \mathrm{kg}^{-1}$ to $261 \mathrm{mg} \mathrm{kg}^{-1}$, higher than the average $\mathrm{Cu}$ concentration (24.7 $\mathrm{mg} \mathrm{kg}^{-1}$ ) of non-anthropogenic affected soils in the US (Table S3). Concentrations of $\mathrm{Cu}, \mathrm{Cr}$ and Fe were found lower in soils collected from high, low and unburned sites of V4 to V6 (Table 1) compared to soil in the channel and banks of the East Fork Jemez River. The higher concentrations of metals in water and soil in a river located near a burned watershed, such as the East Fork Jemez, can increase from the addition of ash and debris by storm water runoff. For example, after the Cerro Grande fire in 2000, elevated concentrations of total $\mathrm{Cu}\left(610 \mu \mathrm{g} \mathrm{L}^{-1}\right)$ and total $\mathrm{Cr}\left(510 \mu \mathrm{g} \mathrm{L}^{-1}\right)$ were measured in post fire runoff water samples collected from the burned watersheds near Guaje Canyon which is close to the Los Alamos National Laboratory. ${ }^{8}$ Additional laboratory experiments were done to determine the concentrations of metals in oven dried wood and ash and assess the reactivity of wood ash upon reaction with $18 \mathrm{M} \Omega$ water.

Acid Extractable Metal Content in Wood Exposed to $60^{\circ} \mathrm{C}, \mathbf{3 5 0}^{\circ} \mathrm{C}$, and $550^{\circ} \mathrm{C}$. We compared the acid extractable metal contents in 9 samples (Pine, Spruce and Aspen at $60^{\circ} \mathrm{C}, 350^{\circ} \mathrm{C}$ and $550^{\circ} \mathrm{C}$, Figure 3, Table S4). Median metal concentrations at $350^{\circ} \mathrm{C}$ (moderate burn) and $550^{\circ} \mathrm{C}$ (high burn) for all tree species (e.g., Pine, Spruce, and Aspen) were significantly higher ( $p<0.05$, Table S5, S6) compared to oven dried wood at $60^{\circ} \mathrm{C}$ (unburned). The acid extractable metal 
concentrations for all samples at $60^{\circ} \mathrm{C}, 350^{\circ} \mathrm{C}$ and $550^{\circ} \mathrm{C}$ are shown in Table S4. Pairwise comparisons suggest that metal contents in oven dried wood at $60^{\circ} \mathrm{C}$ for Pine, Spruce and Aspen were not significantly different from each other $(p>0.05$, Table S5, S6). Among the ash samples at $350^{\circ} \mathrm{C}$ and $550^{\circ} \mathrm{C}$, Pine and Aspen were significantly different $(p<0.05$, Table S6) from each other with respect to acid extractable metal concentrations. Principal Component Analysis (PCA, Figure S2) suggests that $350^{\circ} \mathrm{C}$ and $550^{\circ} \mathrm{C}$ Pine ash samples were associated with high concentrations of most of the metals $(\mathrm{Cu}, \mathrm{Cr}, \mathrm{Si}, \mathrm{Ni}, \mathrm{Fe}, \mathrm{K}$ and $\mathrm{Mg})$. High concentrations of $\mathrm{Ca}$, $\mathrm{Sr}$ and $\mathrm{Zn}$ were associated with $350^{\circ} \mathrm{C}$ and $550^{\circ} \mathrm{C}$ Aspen ash samples, while $350^{\circ} \mathrm{C}$ and $550^{\circ} \mathrm{C}$ Spruce ash samples were associated with high concentrations of $\mathrm{Mn}, \mathrm{Al}$ and $\mathrm{Fe}$.

Major elements $(\mathrm{Ca}, \mathrm{Mg}, \mathrm{K})$ were found to be predominant in oven dried wood $\left(60^{\circ} \mathrm{C}\right)$ and in ash samples $\left(350^{\circ} \mathrm{C}\right.$ and $550^{\circ} \mathrm{C}$ ) for all tree species (Table S4), consistent with findings for wood $^{87}$ and wood $\operatorname{ash}^{23,88}$ from previous studies. Pine ash showed higher concentrations with increasing temperatures for major elements $(\mathrm{Ca}, \mathrm{Mg}$ and $\mathrm{K}$ ) and for heavy metals such $\mathrm{Al}, \mathrm{Fe}, \mathrm{Mn}$ and Ni (Table S4), consistent with findings from a previous study conducted on Lodgepole Pine. ${ }^{51}$ The concentration of $\mathrm{Cu}$ in Pine ash $\left(4997 \pm 262 \mathrm{mg} \mathrm{kg}^{-1}\right.$ at $350^{\circ} \mathrm{C}$ and $2765 \pm 302 \mathrm{mg} \mathrm{kg}^{-1}$ at $550^{\circ} \mathrm{C}$ ) was higher than previously reported values for Pine ash. ${ }^{23,51}$ Due to the dominance of Pine tree species in the forests of western United States, much of the existing literature has focused on the metal and DOC composition of ash produced from different species of Pine (e.g. Ponderosa and Lodgepole). ${ }^{17,23,39,73,89}$ We conducted additional experiments with $350^{\circ} \mathrm{C}$ Pine, Spruce and Aspen ashes to assess the release of dissolved organic carbon and other metals over time.

Metal and DOC Leachates from Pine Ash $\left(350^{\circ} \mathrm{C}\right.$ and $\left.550^{\circ} \mathrm{C}\right)$ Reacted with Water. Metal leaching experiments were conducted to observe the dissolution of selected metals $(\mathrm{Cr}, \mathrm{Ni}, \mathrm{Fe}, \mathrm{Cu}$ and $\mathrm{Zn}$ ) in reaction with $350^{\circ} \mathrm{C}$ and $550^{\circ} \mathrm{C}$ Pine ash in deionized water (Figure 4a to $4 \mathrm{~d}$ ). 
Dissolution of metal bearing phases caused rapid increase in the $\mathrm{pH}$ of water (Figure S3), measured at $10.0 \pm 0.5$ for the duration of the experiment. Less than $3 \%$ by mass [determined in acid extractable analysis (Table S4)] of $\mathrm{Cr}, \mathrm{Ni}, \mathrm{Fe}, \mathrm{Cu}$ and $\mathrm{Zn}$ were released in solution after 72 hours of reaction. Metals like $\mathrm{Cu}, \mathrm{Fe}, \mathrm{Zn}$ and $\mathrm{Ni}$ showed initial release followed by decrease in metal concentration over time for both the $350^{\circ} \mathrm{C}$ and $550^{\circ} \mathrm{C}$ Pine ash (Figure 4a to $4 \mathrm{~d}$ ). Limited fluctuations in the concentration of $\mathrm{Cr}$ released in solution were observed over time (Figure 4b, 4d). The high $\mathrm{pH}$ and alkalinity in these experiments (Figure S3) are likely due to the dissolution of metal bearing carbonate and oxide phases, such as calcite, quartz and whewellite $\left[\mathrm{Ca}\left(\mathrm{C}_{2} \mathrm{O}_{4}\right)\right.$. $\mathrm{H}_{2} \mathrm{O}$ ], which were identified by XRD analysis in the unreacted $350^{\circ} \mathrm{C}$ Pine ash (Figure S4). A previous study from our group also identified the presence of calcite and other metal bearing phases in ash burned at $550^{\circ} \mathrm{C} .^{23}$

The DOC concentration decreased with increasing temperature in reaction of $60^{\circ} \mathrm{C}, 350^{\circ} \mathrm{C}$ and $550^{\circ} \mathrm{C}$ samples with $18 \mathrm{M} \Omega$ water. The $60^{\circ} \mathrm{C}$ (unburned) samples released higher DOC concentrations (110.7 to $338 \mathrm{mg}$ carbon L-1) compared to $350^{\circ} \mathrm{C}$ ( 4.25 to $11.3 \mathrm{mg}$ carbon L-1) and $550^{\circ} \mathrm{C}$ ash samples (1.27 to $2.77 \mathrm{mg}$ carbon L-1) (Figure 4e, 4f). In this study, different sections (i.e. leaves, twigs, needles) of the collected tree species were crushed and ground to powders and homogenized before conducting the experiments. This process could have contributed to the high DOC release from the unburned samples. Additionally, a variable release of DOC could result from contributions from different tree sections, obtaining DOC concentrations that are higher than the ones reported in this study..$^{90,91}$ The decrease in DOC concentration from $350^{\circ} \mathrm{C}$ to $550^{\circ} \mathrm{C}$ ash suggests that a greater loss of organic matter occurs at a higher burning temperature, consistent with findings from previous studies. ${ }^{23,33}$ The range of DOC concentrations (1.27 to $11.3 \mathrm{mg}$ carbon $\mathrm{L}^{-1}$ ) measured for $350^{\circ} \mathrm{C}$ and $550^{\circ} \mathrm{C}$ ash samples in this study are consistent with those reported in 
previous studies from field ${ }^{17,25}$ and laboratory studies. ${ }^{33}$ Previously. Wang et al. ${ }^{39}$ observed decreased reactivity of the ash in forming DBPs such as trihalomethane (THM) and chloral hydrate (CHD) with increasing temperature from $50^{\circ} \mathrm{C}$ to $400^{\circ} \mathrm{C}$. The DOC loss at higher temperatures for ash in this study is comparable to that observed in laboratory heated soil by Cawley et al. ${ }^{33}$ Thus, the temperature dependent variability for both ash and soil can have implications in terms of variable loading of DOM and DBP precursors from different burn conditions associated with wildfires and prescribed fires, as suggested by others. ${ }^{33,39}$

Sorption to $350^{\circ} \mathbf{C} \mathbf{A s h}$. We further explored the sorption of $\mathrm{Cu}$ (II) (a cationic metal) and $\mathrm{Cr}(\mathrm{VI})$ (an oxyanion) to $350^{\circ} \mathrm{C}$ ash at $\mathrm{pH} 7.0 \pm 0.2$ in batch sorption experiments. Zeta potential measurements for the $350^{\circ} \mathrm{C}$ Pine ash showed increasingly negative surface charge with increasing solution $\mathrm{pH}$ (Figure S5), similar to another carbon-based material like biochar. ${ }^{67,69}$ The surface area of Pine ash increased from $36.9 \mathrm{~m}^{2} / \mathrm{g}$ at $350^{\circ} \mathrm{C}$ to $294.4 \mathrm{~m}^{2} / \mathrm{g}$ at $550^{\circ} \mathrm{C}$ (Table S7). Previously, Mendonça et al. ${ }^{69}$ reported increase in surface area due to creation of micropores for biochar burned at $400^{\circ} \mathrm{C}$ and $600^{\circ} \mathrm{C}$. Higher loss of $\mathrm{C}, \mathrm{H}$ and $\mathrm{O}$ occurred in ash with increasing temperature (Table S8). Lower $\mathrm{H} / \mathrm{C}$ ratios in $350^{\circ} \mathrm{C}$ and $550^{\circ} \mathrm{C}$ can be a measure of higher degree of aromaticity in the ash samples, as suggested by previous studies on biochar. ${ }^{67,92}$ Higher $\mathrm{O} / \mathrm{C}$ and $(\mathrm{O}+\mathrm{N}) / \mathrm{C}$ ratios, for the $350^{\circ} \mathrm{C}$ and $550^{\circ} \mathrm{C}$ ash samples, are indicators of increased hydrophilicity and polarity ${ }^{67,92,93}$ We observed more than $80 \%$ decrease initially in $\mathrm{Cu}(\mathrm{II})$ concentration in solution reacting with $350^{\circ} \mathrm{C}$ Pine ash (Figure 5a), as indicated by measured $\mathrm{Cu}(\mathrm{II})$ concentration (103.6 \pm $3.1 \mu \mathrm{g} \mathrm{L}^{-1}$ ) after 5 mins of reaction and up to $92 \%$ decrease after 180 mins of reaction. $\mathrm{Cu}(\mathrm{II})$ concentration in the control decreased only $5 \%$, to $601.2 \pm 53.8 \mu \mathrm{g} \mathrm{L}^{-1}$ after 180 mins of reaction from the initially added concentration of $635 \mu \mathrm{g} \mathrm{L}{ }^{-1}$. In experiments with $\mathrm{Cr}(\mathrm{VI})$, low decrease in $\mathrm{Cr}(\mathrm{VI})$ concentration was observed, as the measured concentration after 180 mins was $451.7 \pm 7.8$ 
$\mu \mathrm{g} \mathrm{L} \mathrm{L}^{-1}$, representing only $13 \%$ decrease from the initially added $\mathrm{Cr}(\mathrm{VI})$ of $520 \mu \mathrm{g} \mathrm{L}^{-1}$ (Figure $5 \mathrm{~b}$ ). $\mathrm{Cr}(\mathrm{VI})$ showed negligible decrease in concentration in the $\mathrm{Cr}(\mathrm{VI})$-control experiment (Figure 5b). Similar results were observed for both $\mathrm{Cu}(\mathrm{II})$ and $\mathrm{Cr}(\mathrm{VI})$ in the sorption experiments with $350^{\circ} \mathrm{C}$ Spruce and Aspen ashes (Figure S6). These results suggest that burning caused similar effects on metal reactivity of all three ashes (Pine, Spruce and Aspen).

The different response of $\mathrm{Cu}(\mathrm{II})$ and $\mathrm{Cr}(\mathrm{VI})$ concentration during the sorption experiments suggests that high $\mathrm{Cu}(\mathrm{II})$ association to ash occurred due to possible electrostatic attraction of the positively charged $\mathrm{Cu}(\mathrm{II})$ to the negatively charged ash surface. The effect of sorption capacity of the carbonate phases in wood ash in reacting with cations such as $\mathrm{Ca}^{+2}, \mathrm{Mg}^{+2}, \mathrm{Al}^{+3}, \mathrm{Mn}^{+2}, \mathrm{Fe}^{+2}$, $\mathrm{Pb}^{+2}, \mathrm{Cu}^{+2}, \mathrm{Zn}^{+2}$ and $\mathrm{Cd}^{+2}$ has been discussed in other studies. ${ }^{23,72}$ This is a relevant property of wood ash that should be considered when investigating the persistence of metals such as $\mathrm{Cu}, \mathrm{Pb}$, $\mathrm{Ni}, \mathrm{Fe}, \mathrm{Zn}$ associated with ash and debris in wildfire affected watersheds, as reported in several post-fire investigations. ${ }^{9,10,74}$ The low sorption of $\mathrm{Cr}(\mathrm{VI})$ observed in this study is consistent with other studies reporting low sorption rates for $\mathrm{As}(\mathrm{V}), \mathrm{Cr}(\mathrm{VI})$ and $\mathrm{Se}(\mathrm{VI})$ to carbonaceous materials at pH 5.0 and above. ${ }^{94-96}$ For example, a recent study by Alam et al. observed over $90 \%$ removal of $\mathrm{Cd}(\mathrm{II})$ and below $20 \%$ removal for $\mathrm{Se}(\mathrm{VI})$ at $\mathrm{pH} 6.0$ and above, using biochar as an adsorbent. ${ }^{94}$ At the experimental $\mathrm{pH}$ of $7.0 \pm 0.2$ used in this study, $\mathrm{Cr}(\mathrm{VI})$ is expected to exist in the solution as stable oxyanion forms (e.g., $\left.\mathrm{CrO}_{4}{ }^{2-}, \mathrm{HCrO}_{4}^{-}\right) .{ }^{97}$ Therefore, the electrostatic repulsion between the negatively charged ash surface and $\mathrm{Cr}(\mathrm{VI})$ oxyanions can account for the low decrease in $\mathrm{Cr}(\mathrm{VI})$ concentration in solution. The association of $\mathrm{Cu}(\mathrm{II})$ in the unreacted and reacted $350^{\circ} \mathrm{C}$ Pine ash solids were further analyzed using microscopy and spectroscopy.

Solid Phase Analyses of Unreacted and Reacted $350^{\circ}$ C Pine Ash. SEM analysis detected the presence of $\mathrm{Cu}$ on $350^{\circ} \mathrm{C}$ Pine ash before and after exposure to batch experiments (Figure S7). For 
example, EDS spectra of a $\mathrm{Cu}$ grain showed $69.51 \mathrm{wt} \%$ of $\mathrm{Cu}$ for the unreacted ash, and $63.55 \mathrm{wt}$ $\%$ of $\mathrm{Cu}$ for the reacted ash. SEM/EDS results confirmed the high $\mathrm{Cu}$ concentration $(4997 \pm 262$ $\mathrm{mg} \mathrm{kg}^{-1}$ ) measured from the acid extraction analyses. Electron microprobe mapping detected low level of $\mathrm{Cu}(0.012 \%)$ associated with the $\mathrm{Ca}^{+2}$ minerals in the reacted ash (Figure S8), while below detection limit for the unreacted ash. The predominant form of the $\mathrm{Ca}^{+2}$ mineral is most likely calcite $\left(\mathrm{CaCO}_{3}\right)$, given the presence of $76-78 \mathrm{wt} \%$ of calcite in the reacted sample (Figure S4). Given that $\mathrm{Ca}$ is a macronutrient in plants, $\mathrm{Ca}^{+2}$ minerals in the form of $\mathrm{CaO}$ and $\mathrm{CaCO}_{3}$ are abundant across a variety of plant cells. ${ }^{98,99}$ XRD analyses on reacted and unreacted samples indicated presence of quartz and calcite $\left(\mathrm{CaCO}_{3}\right)$ as predominant mineral phases (Figure S4). While microscopy analyses identified the presence of $\mathrm{Cu}$, it was challenging to obtain specific information about the association of $\mathrm{Cu}$ on the reacted ash surface from these analyses. Thus, additional analyses using XPS were done to measure the signal of $\mathrm{Cu} 2 \mathrm{p}$ on the "near-surface" region to identify the possible association of $\mathrm{Cu}$ to ash after reaction in batch sorption experiments.

Results from XPS survey scan revealed that $0.11 \% \mathrm{Cu} 2 \mathrm{p}$ was present in the reacted ash, suggesting that $\mathrm{Cu}$ is associated at the top 5-10 $\mathrm{nm}$ of the ash "near surface" region (Table $\mathrm{S} 9$ ). However, the $\mathrm{Cu} 2 \mathrm{p} \%$ for the unreacted ash was below detection limit (Table S9). So, the high resolution $\mathrm{Cu} 2 \mathrm{p}$ peak obtained for the unreacted ash was noisy and could not be used for curve fitting analyses (Figure 6). Curve fitting of high resolution XPS $\mathrm{Cu} 2 \mathrm{p}$ spectra obtained for the reacted sample was conducted using reference spectra for $\mathrm{CuO}, \mathrm{CuCO}_{3}, \mathrm{Cu}_{2} \mathrm{O}$ and $\mathrm{Cu}$ metal as indicated in the Materials and Methods section. Curve fitting analysis suggests that the main species of $\mathrm{Cu}$ present on the reacted ash are: $\mathrm{Cu}(\mathrm{II})$ in the form of $\mathrm{CuO}(64.2 \%)$ and $\mathrm{CuCO}_{3}$ (18.6\%), and $\mathrm{Cu}(\mathrm{I})$ in the form of $\mathrm{Cu}_{2} \mathrm{O}$ (17.3\%) (Figure 6). The presence of $\mathrm{Cu}(\mathrm{I})$ on the reacted 
ash surface suggests possible reduction of some of the $\mathrm{Cu}(\mathrm{II})$ to $\mathrm{Cu}(\mathrm{I})$, as suggested by a previous study by Bogusz et al. ${ }^{93}$

The association of $\mathrm{Cu}$ on the reacted $350^{\circ} \mathrm{C}$ Pine ash near surface region suggests a likely surface controlled process involved in the removal of $\mathrm{Cu}(\mathrm{II})$ in the sorption experiments. Curve fitting analysis of $\mathrm{C} 1 \mathrm{~s}$ high resolution spectra showed an increase in the percentages of $\mathrm{C}^{*}-\mathrm{CO}_{\mathrm{x}}$, $\mathrm{C}=\mathrm{O}$ and $\mathrm{C}-\mathrm{OH}$ bonds in the reacted ash (Figure $\mathrm{S} 9)$. The presence of surface functional groups ($\mathrm{C}=\mathrm{O},-\mathrm{COOH})$ in ash can act as negatively charged binding sites for positively charged cations. The increased polarity (higher $\mathrm{O} / \mathrm{C}$ and $(\mathrm{O}+\mathrm{N}) / \mathrm{C}$ ratios) in the ash samples measured by the $\mathrm{C}, \mathrm{H}$, $\mathrm{N}, \mathrm{O}$ analyses (Table S8) is consistent with the increase in functional groups, identified by XPS. The removal of cationic metals such as $\mathrm{Cu}^{+2}$ and $\mathrm{Cd}^{+2}$ through associations with surface functional groups of biochar has been discussed in the literature. ${ }^{58,93,100}$ These properties are also relevant to better understand the effect of burned soil and ash on post fire mobilization of heavy metals.

\section{Environmental Implications}

The results from this investigation indicate how metal and DOC content associated with ash burned at different temperatures $\left(350^{\circ} \mathrm{C}\right.$ and $\left.550^{\circ} \mathrm{C}\right)$ can differ for Pine, Spruce and Aspen. This outcome may have relevant implications when considering the wide variation in vegetation across large watersheds when assessing response to wildfire events. Ash burned at $350^{\circ} \mathrm{C}$ had higher DOC concentration in water compared to ash burned at $550^{\circ} \mathrm{C}$. This observed increase may have important implications in terms of increased DOC fluxes in post fire watersheds from moderately burned ash and soil reported in previous studies. ${ }^{25,101}$ The batch experiments conducted in $18 \mathrm{M} \Omega$ water indicate that metals such as $\mathrm{Cr}, \mathrm{Ni}, \mathrm{Fe}, \mathrm{Cu}$ and $\mathrm{Zn}$ were dissolved in the initial stages of the experiment, followed by decrease in concentration over the duration of the experiment. This observation is consistent with a previous study suggesting that metal ( $\mathrm{Ca}, \mathrm{Mg}, \mathrm{Al}, \mathrm{Fe}$ and $\mathrm{Mn}$ ) 
dissolution occurred in initial stages of the batch experiments conducted with ash from Pine, Aspen and Spruce trees from the Caldera, followed by re-association of these metals to ash over time. ${ }^{23}$ However, a new finding was obtained from the sorption experiments conducted in this study which indicate that up to $94 \%$ of $\mathrm{Cu}$ is removed from solution after 180 mins of reaction due to association of this metal in the $350^{\circ} \mathrm{C}$ Pine ash surface. A similar behavior is expected for other positive cations such as $\mathrm{Ca}^{2+}, \mathrm{Mg}^{2+}, \mathrm{Zn}^{2+}, \mathrm{Al}^{+3}, \mathrm{Fe}^{+2}, \mathrm{Cd}^{+2}, \mathrm{~Pb}^{+2}$ among others, as suggested in other studies related to wood $\operatorname{ash}^{23,72}$ and biochar ${ }^{57,102}$ reactivity. The integration of results from the metal dissolution and sorption experiments in this study provide novel insights about post fire mobilization of cationic metals in burned watersheds. However, oxyanions such as $\mathrm{Cr}(\mathrm{VI})$ are expected to have limited association to ash in natural $\mathrm{pH}$ conditions and are likely to have higher mobility in watersheds affected by wildfires. Future experiments are necessary to study metal reactivity in wood ash in dynamic flow conditions which allow interactions between ash and sediments in water. This study provides relevant insights on water quality that could be considered for post fire response and recovery strategies by local authorities.

\section{Acknowledgements}

Thanks to Dr. Robert Parmenter for scientific advice and support for this study. Funding for this research was provided by the Oak Ridge Associated Universities (ORAU) Program Ralph E. Powe Jr. Junior Faculty Enhancement Award, the New Mexico Water Resources Research Institute, and the National Science Foundation under New Mexico EPSCoR (Grant Number \#IIA1301346), and CREST (Grant Number 1345169). Any opinions, findings, and conclusions or recommendations expressed in this publication are those of the author(s) and do not necessarily reflect the views of the National Science Foundation. 
Table 1. Elemental content of water (site 1 to 5) and soil (site V1 to V3) samples ${ }^{a}$ from the East Fork Jemez River within the Valle Grande area in VALL. Site V4 to V6 contain soil samples from the hill slope of the Sierra de Los Valles dome located near the headwaters of the river. Ranges of concentrations (minimum to maximum) for each site is shown.

\begin{tabular}{|c|c|c|c|c|c|c|c|c|}
\hline \multirow[b]{2}{*}{ Site } & \multirow[b]{2}{*}{ pH } & \multirow[b]{2}{*}{$\begin{array}{c}\text { Alkalinity } \\
\left(\mathrm{mg} \mathrm{L}^{-1}\right)\end{array}$} & \multirow[b]{2}{*}{$\begin{array}{c}\text { TOC } \\
\left(\mathrm{mg} \mathrm{C} \mathrm{L} \mathrm{L}^{-1}\right)\end{array}$} & \multicolumn{5}{|c|}{ Water elemental content $\left(\mu g L^{-1}\right)$} \\
\hline & & & & $\begin{array}{c}\mathrm{Cu} \\
\text { Total }\end{array}$ & $\begin{array}{c}\mathrm{Cr} \\
\text { Total }\end{array}$ & $\begin{array}{c}\mathrm{Fe} \\
\text { Total }\end{array}$ & $\begin{array}{c}\text { Zn } \\
\text { Total } \\
\end{array}$ & $\begin{array}{c}\text { Mn } \\
\text { Total } \\
\end{array}$ \\
\hline Site 1 & $7.17-8.44$ & $30.5-42.0$ & $0.80-2.00$ & $2.81-16.7$ & $\mathrm{BDL}^{\mathrm{b}}-105$ & $289-932$ & $52.2-103$ & $6.90-57.2$ \\
\hline Site 2 & $7.11-8.06$ & $31.0-38.3$ & $1.60-10.8$ & $5.44-37.4$ & BDL - 8.20 & $465-2650$ & $41.4-335$ & $8.83-146$ \\
\hline Site 3 & $6.55-7.66$ & $24.1-43.8$ & $4.00-10.3$ & $7.93-23.4$ & BDL - 48.4 & $38.2-677$ & $57.4-352$ & $1.58-39.2$ \\
\hline Site 4 & $6.48-8.01$ & $38.7-43.7$ & $4.60-11.3$ & $5.31-21.7$ & BDL - 16.5 & $358-757$ & $60.7-241$ & $6.56-22.4$ \\
\hline Site 5 & $6.48-7.97$ & $33.8-40.9$ & $3.20-11.0$ & BDL - 25.2 & BDL - 11.5 & $331-948$ & $72.8-135$ & BDL - 44.4 \\
\hline \multicolumn{4}{|c|}{ Soil sampling sites } & \multicolumn{5}{|c|}{ Soil elemental content $\left(\mathrm{mg} \mathrm{kg}^{-1}\right)$} \\
\hline \multicolumn{4}{|c|}{ Site V1 } & $59.4-86.9$ & $10.9-35.3$ & $7800-9620$ & $13.0-38.5$ & $219-319$ \\
\hline \multicolumn{4}{|c|}{ Site V2 } & $71.3-89.9$ & $9.25-20.4$ & $4980-9850$ & $10.2-31.4$ & $50.8-194$ \\
\hline \multicolumn{4}{|c|}{ Site V3 } & $44.2-261$ & $11.0-17.2$ & $5050-7940$ & $14.9-37.9$ & $92.7-139$ \\
\hline \multicolumn{4}{|c|}{ Site V4 (High burn) } & $7.16-17.5$ & $5.81-13.3$ & $109-221$ & $19.5-35.2$ & $260-347$ \\
\hline \multicolumn{4}{|c|}{ Site V5 (Low burn) } & $5.97-18.6$ & $4.96-15.2$ & $86.4-190$ & $22.2-54.2$ & $179-344$ \\
\hline \multicolumn{4}{|c|}{ Site V6 (Unburned) } & $7.97-13.9$ & $5.31-11.3$ & $102-184$ & $30.8-39.4$ & $217-454$ \\
\hline
\end{tabular}

\footnotetext{
${ }^{a}$ Aqueous and soil elemental content measured with ICP-OES and ICP-MS $\boldsymbol{b}_{B D L}=$ Below detection limit
} 

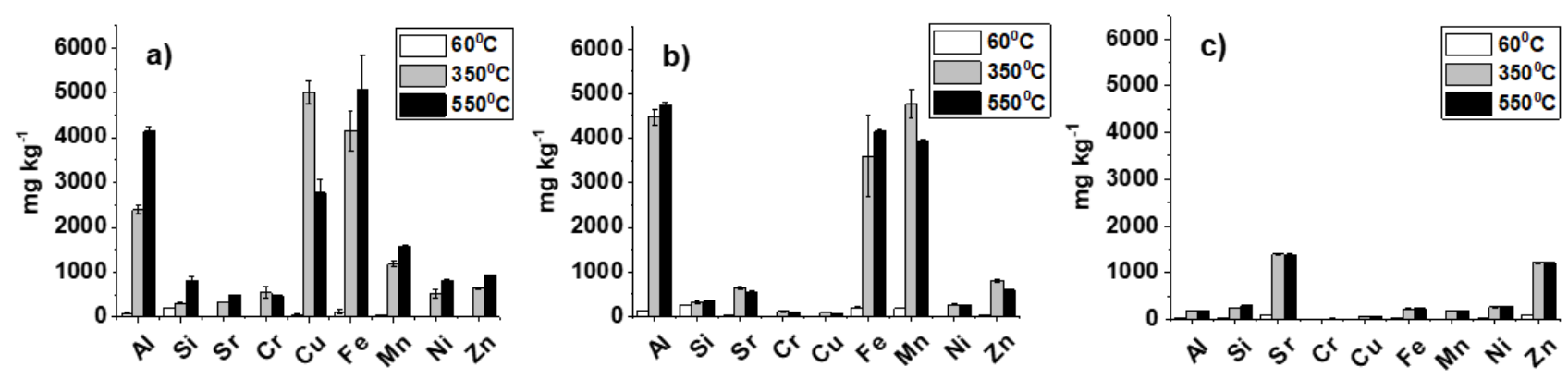

Figure 3. Acid extractable concentrations (mean \pm SD) of 9 metals varied across different tree species of (a) Pine, (b) Spruce and (c) Aspen. The major elements ( $\mathrm{Ca}, \mathrm{Mg}$ and $\mathrm{K}$ ) were predominant in all tree species at $60^{\circ} \mathrm{C}, 350^{\circ} \mathrm{C}$ and $550^{\circ} \mathrm{C}$ (Table S2). Ash produced at both $350^{\circ} \mathrm{C}$ (moderate burn) and $550^{\circ} \mathrm{C}$ (high burn) contained higher metal concentrations than in samples dried at $60^{\circ} \mathrm{C}$ (unburned) for all species. 
Dissolution of metals (Fe, $\mathrm{Cu}, \mathrm{Zn}, \mathrm{Cr}, \mathrm{Ni})$

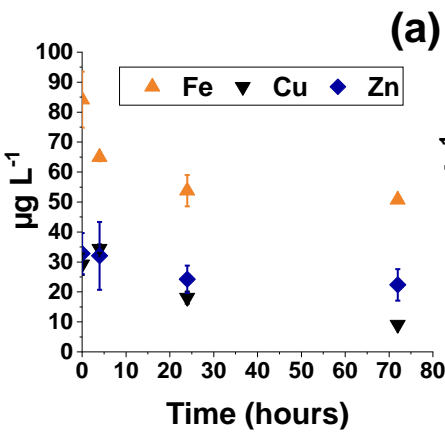

(a)

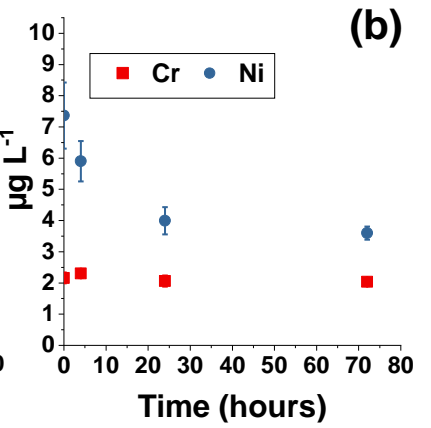

(c)

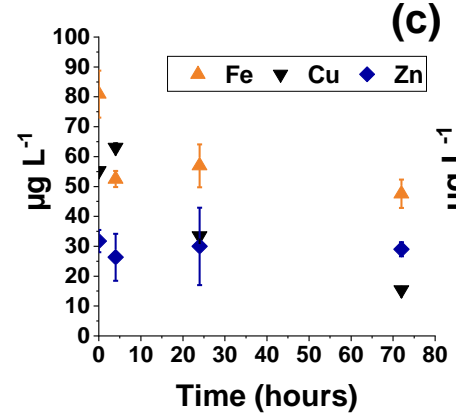

(d)
DOC concentration
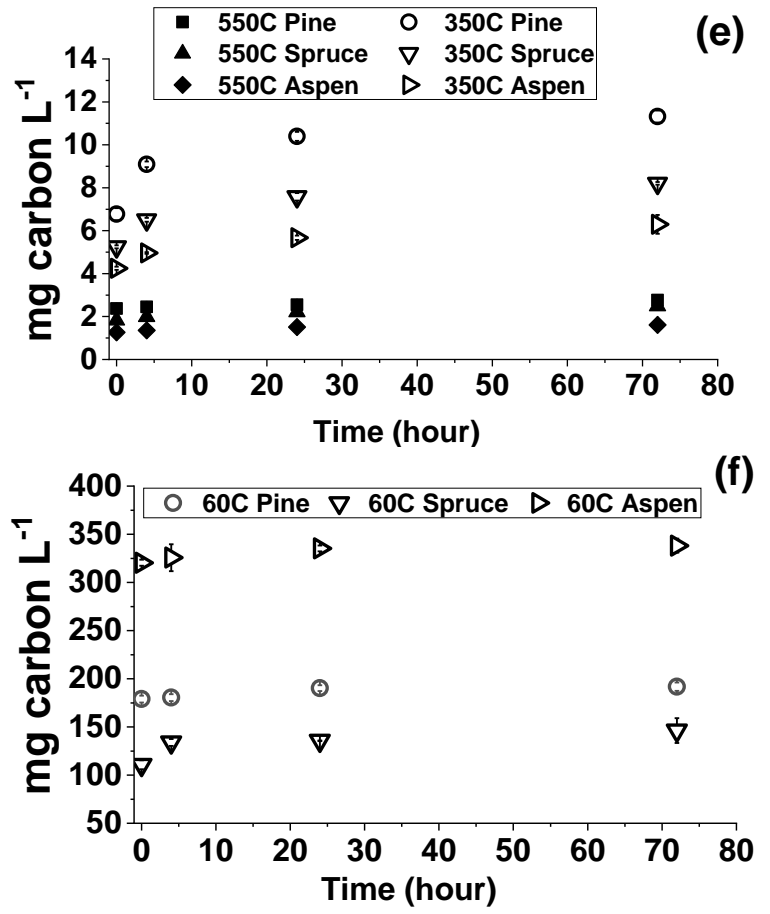

Figure 4. Concentrations of (a) $\mathrm{Fe}, \mathrm{Cu}, \mathrm{Zn}$ and (b) $\mathrm{Cr}$, Ni at $0,4,24$ and 72 hours in reaction of $550^{\circ} \mathrm{C}$ Pine ash with $18 \mathrm{M} \Omega$ water. In figures (c) and (d), metal concentrations are shown for reaction of $350^{\circ} \mathrm{C}$ Pine ash with $18 \mathrm{M} \Omega$ water. DOC concentration (mg carbon $\left.\mathrm{L}^{-1}\right)$ at $0,4,24$ and 72 hours $(\mathrm{n}=3)$ is shown in figure (e) for $350^{\circ} \mathrm{C}$ and $550^{\circ} \mathrm{C}$ ash samples and in (f) $60^{\circ} \mathrm{C}$ crushed wood samples. 

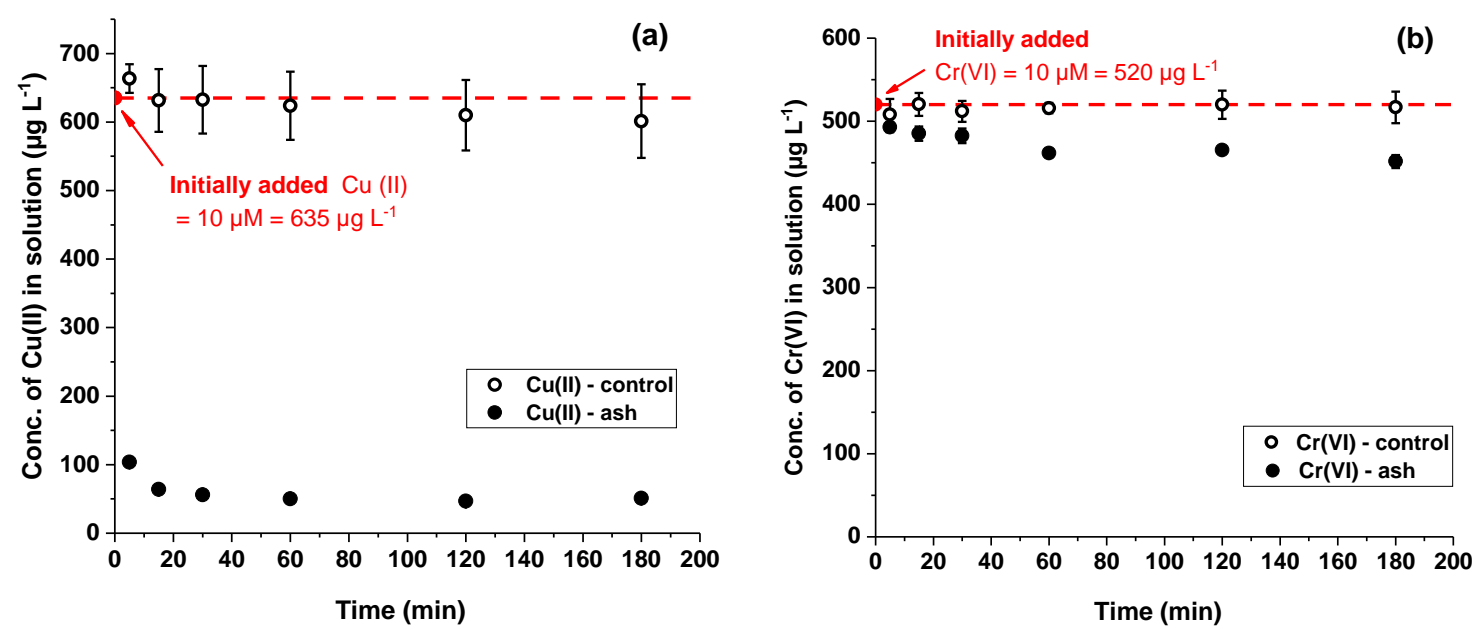

Figure 5. Results from the metal sorption experiments $(n=3$, sampling interval $=5 \mathrm{~min}, 15 \mathrm{~min}$,

$30 \mathrm{~min}, 1 \mathrm{hr}, 2 \mathrm{hrs}$ and $3 \mathrm{hrs}$ ) conducted by reacting $10 \mu \mathrm{M}$ of (a) $\mathrm{Cu}(\mathrm{II})$ and (b) $\mathrm{Cr}(\mathrm{VI})$ separately in a solution containing $0.1 \mathrm{~g}$ of $350^{\circ} \mathrm{C}$ Pine ash with $50 \mathrm{~mL}$ of $18 \mathrm{M} \Omega$ water. Note that the control experiments were conducted by reacting $10 \mu \mathrm{M}$ of $\mathrm{Cu}(\mathrm{II})$ and $\mathrm{Cr}(\mathrm{VI})$ in $18 \mathrm{M} \Omega$ water without ash. 

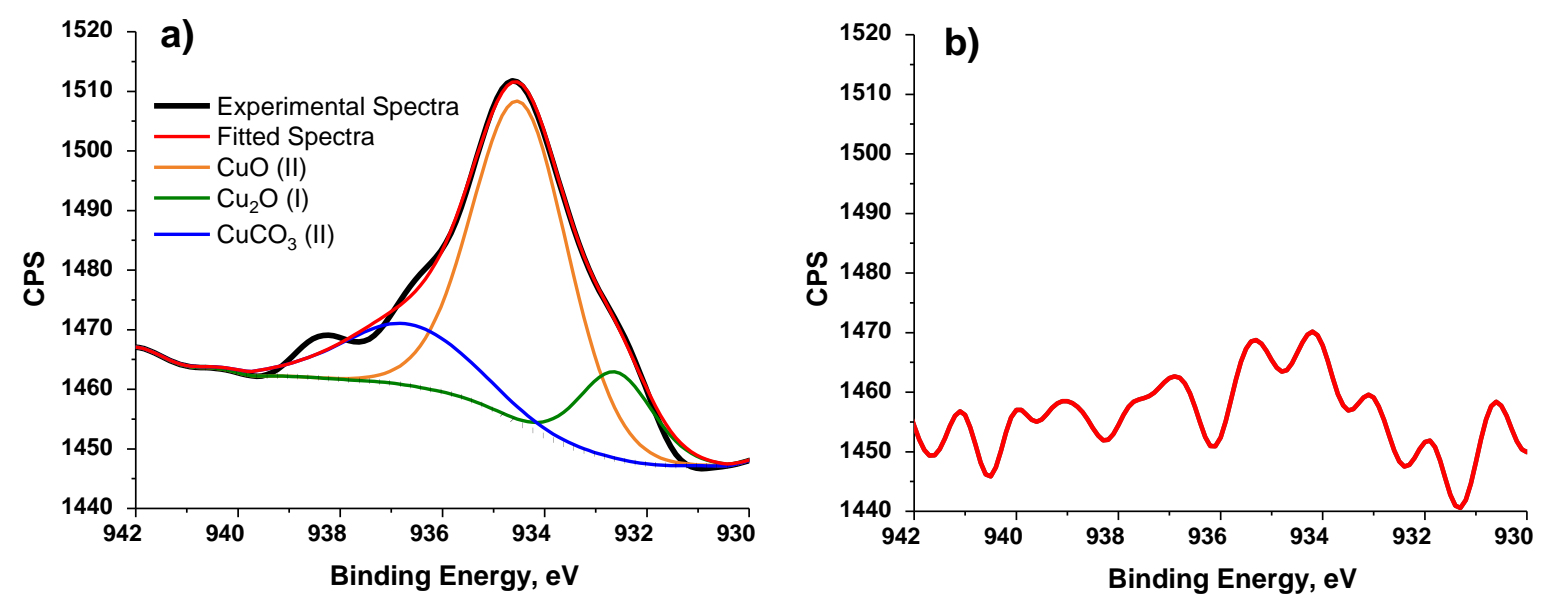

c)

$\%$ Content

\begin{tabular}{lccc}
\cline { 2 - 4 } Sample & $\mathrm{Cu}_{2} \mathrm{O}(\mathrm{I})$ & $\mathrm{CuO}(\mathrm{II})$ & $\mathrm{CuCO}_{3}(\mathrm{II})$ \\
\hline Binding energy, $\mathbf{e V}$ & $\mathbf{9 3 2 . 2}$ & $\mathbf{9 3 4}$ & $\mathbf{9 3 6}$ \\
\hline Unreacted $350^{\circ} \mathrm{C}$ Pine ash & $\mathrm{BDL}^{1}$ & $\mathrm{BDL}^{1}$ & $\mathrm{BDL}^{1}$ \\
Reacted $350^{\circ} \mathrm{C}$ Pine ash & 17.26 & 64.17 & 18.56 \\
\hline & \multicolumn{3}{c}{ Below detection limit }
\end{tabular}

Figure 6. $\mathrm{Cu} 2 \mathrm{p}$ high resolution spectra for the (a) Reacted $350^{\circ} \mathrm{C}$ Pine ash and (b) Unreacted $350^{\circ} \mathrm{C}$ Pine ash (c) Percentages of different oxidation states in the $\mathrm{Cu} 2 \mathrm{p}$ spectra for the reacted ash determined by using reference $\mathrm{Cu} 2 \mathrm{p}$ spectra for $\mathrm{CuO}, \mathrm{CuCO}_{3}, \mathrm{Cu}_{2} \mathrm{O}$ and $\mathrm{Cu}$ metal. 


\section{Appendix: Supporting Information}

\section{Metal Reactivity in Laboratory Burned Wood from a Watershed Affected by Wildfires}

\section{$\underline{\text { Additional Materials and Methods. }}$}

Wood Sampling Methods. Wood samples of Ponderosa Pine, Quaking Aspen and Colorado Blue Spruce were collected from the Valles Caldera National Preserve area in New Mexico. We collected tree branches with attached twigs, leaves and needles from unburned live trees. The collected tree branches were crushed to powders using a laboratory milling machine and then oven dried for at $60^{\circ} \mathrm{C}$ for 48 hours before burning.

Water and Soil Sampling Methods. Surface water samples were collected as grab samples in $125 \mathrm{~mL}$ polypropylene bottles after three rinses. Samples for dissolved analysis were filtered through a $0.45 \mu \mathrm{m}$ filter. Samples for metals' analysis were acidified to a $\mathrm{pH}$ of 2 with nitric acid. Soil samples were collected using a soil auger down to 6 inches and homogenized prior to preparation for analysis.

Solid Phase Analyses. Elemental composition and the oxidation states in the near surface (5-10 nm) were acquired using a Kratos Axis DLD Ultra X-ray photoelectron spectrometer. A monochromatic $\mathrm{Al} \mathrm{K \alpha}$ source was used, operating at $225 \mathrm{~W}$ with no charge compensation. The $\mathrm{Cu}$ $2 \mathrm{p}$ spectra from reference $\mathrm{Cu}$ samples were used to identify the species of $\mathrm{Cu}$ present on the near surface region of the reacted ash sample. Reference $\mathrm{Cu}$ samples ( $\mathrm{Cu}$ metal, $\mathrm{Cu}(\mathrm{I}, \mathrm{II})$ oxide and Copper(II) carbonate basic) were purchased from Sigma Aldrich, Strem Chemicals and Alfa Aesar respectively. All the chemicals were $>99 \%$ pure except the Copper(II) carbonate basic ( $\geq 95 \%$ purity). The high-resolution spectra, along with the binding energies obtained for the $\mathrm{Cu} 2 \mathrm{p}$ regions 
for these reference materials are shown in Figure S10. Curve fitting and quantification were performed using CasaXPS software. Spectra of all the samples were calibrated using gold powder deposited on each sample with respect to the $\mathrm{Au} 4 \mathrm{f}$ peak position at $84 \mathrm{eV}$. Electron scattering background was removed using a Shirley background; curve fitting of spectra was done using a 70\% Gaussian/30\% Lorentzian [GL (30)] line shape. Qualitative mapping of the ash samples was done using an electron probe microanalyzer (EPMA) using wavelength dispersive X-ray spectroscopy (WDS). A JEOL JXA-8200 Super-Probe was used, operating at $10 \mathrm{kV}$ with a $10 \mu \mathrm{m}$ probe diameter and $30 \mathrm{nA}$ probe current.

\section{Characterization of $60^{\circ} \mathrm{C}, 350^{\circ} \mathrm{C}$ and $550^{\circ} \mathrm{C}$ samples (BET, zeta potential and $\mathrm{C}, \mathrm{H}, \mathrm{N}, \mathrm{O}$}

analysis). The Brunauer-Emmett-Teller (BET) specific surface area for the $350^{\circ} \mathrm{C}$ and $550^{\circ} \mathrm{C}$ ash samples were measured using a Gemini 2360 V5 surface area analyzer. The zeta potential of the ash samples was determined using a Malvern Zetasizer Nano-ZS equipped with a He-Ne laser (633nm) and non-invasive backscatter optics (NIBS). $\mathrm{N}$ and $\mathrm{C}$ contents (wt $\%$ ) for $60^{\circ} \mathrm{C}, 350^{\circ} \mathrm{C}$ and $550^{\circ} \mathrm{C}$ samples were measured using a Costech ECS 4010 Elemental Analyzer coupled to a Thermo Fisher Scientific Delta V Advantage mass spectrometer via a CONFLO IV interface. O and $\mathrm{H}$ contents (wt \%) were measured using a Thermo Chemical Elemental Analyzer (TCEA) coupled to a Thermo Fisher Scientific Delta V Advantage. Wt \% C, H, N and O values were calculated using the Elemental Spruce Powder Standard B2213. 
Table S1. Mass of wood (e.g., pine spruce and aspen) samples for (a) oven drying and (b) burning procedure of wood samples.

a)

\begin{tabular}{|c|c|c|c|c|c|c|c|}
\hline \multirow{2}{*}{$\begin{array}{l}\begin{array}{l}\text { Sample } \\
\text { Name }\end{array} \\
\text { Pine }\end{array}$} & \multicolumn{2}{|c|}{$\begin{array}{l}\text { Mass before oven } \\
\text { drying at } 60^{\circ} \mathrm{C} \\
\text { for } 48 \text { hours }(\mathrm{g})\end{array}$} & \multicolumn{2}{|c|}{$\begin{array}{l}\text { Mass after oven } \\
\text { drying at } 60^{\circ} \mathrm{C} \\
\text { for } 48 \text { hours }(\mathrm{g})\end{array}$} & $\begin{array}{l}\text { \% mass lost } \\
\text { (moisture } \\
\text { content) }\end{array}$ & \multicolumn{2}{|c|}{$\begin{array}{l}\text { \% mass remaining } \\
\text { due to loss of } \\
\text { moisture content }\end{array}$} \\
\hline & 2164 & & & 1612 & 25.5 & & 74.5 \\
\hline Spruce & 3342 & & & 2762 & 17.4 & & 82.6 \\
\hline Aspen & 2802 & & & 2173 & 22.4 & & 77.6 \\
\hline \multicolumn{8}{|l|}{ b) } \\
\hline $\begin{array}{l}\text { Sample } \\
\text { Name }\end{array}$ & $\begin{array}{l}\text { Mass } \\
\text { before } \\
\text { burning at } \\
550^{\circ} \mathrm{C} \text { for } 4 \\
\text { hours }(\mathrm{g})\end{array}$ & $\begin{array}{l}\text { Mass } \\
\text { burni } \\
\mathbf{5 5 0}^{\circ} \mathrm{C} \\
\text { hours }\end{array}$ & $\begin{array}{l}\text { after } \\
\text { ng at } \\
\text { for } 4 \\
(\mathrm{~g})\end{array}$ & $\begin{array}{l}\% \text { mass } \\
\text { remaining } \\
\text { after } \\
\text { burning }\end{array}$ & $\begin{array}{l}\text { Mass } \\
\text { before } \\
\text { burning at } \\
350^{\circ} \mathrm{C} \text { for } \\
4 \text { hours (g) }\end{array}$ & $\begin{array}{l}\text { Mass after } \\
\text { burning at } \\
350^{\circ} \mathrm{C} \text { for } \\
4 \text { hours (g) }\end{array}$ & $\begin{array}{l}\text { \% mass } \\
\text { remaining } \\
\text { after } \\
\text { burning }\end{array}$ \\
\hline Pine & 450.2 & 22.55 & & 5.01 & 200.2 & 7.32 & 3.66 \\
\hline Spruce & 450.4 & 17.16 & & 3.81 & 200.2 & 6.96 & 3.48 \\
\hline Aspen & 450.1 & 24.01 & & 5.33 & 200.2 & 10.94 & 5.47 \\
\hline
\end{tabular}


Table S2. Detection limits for analyses using: a) inductively coupled plasma optical emission spectrometry (ICP-OES), and b) inductively coupled plasma mass spectrometry (ICP-MS).

\section{a) ICP-OES}

\begin{tabular}{lll}
\hline Element & IDL $\left(\mathbf{m g ~ L}^{-\mathbf{1}}\right)$ & MDL $\left(\mathbf{m g ~ L}^{-\mathbf{1}}\right)$ \\
\hline $\mathrm{Al}$ & 0.0280 & 0.0280 \\
$\mathrm{Ca}$ & 0.0100 & 0.0100 \\
$\mathrm{Cu}$ & 0.0054 & 0.0054 \\
$\mathrm{Fe}$ & 0.0062 & 0.0062 \\
$\mathrm{Mg}$ & 0.0030 & 0.0030 \\
$\mathrm{Mn}$ & 0.0014 & 0.0014 \\
$\mathrm{Ni}$ & 0.0150 & 0.0150 \\
$\mathrm{~Pb}$ & 0.0420 & 0.0420 \\
$\mathrm{~V}$ & 0.0064 & 0.0064 \\
$\mathrm{Zn}$ & 0.0018 & 0.0018
\end{tabular}

b) ICP-MS

\begin{tabular}{lll}
\hline Element & IDL $\left(\mathbf{m g ~ L}^{\mathbf{- 1}}\right)$ & MDL $\left(\mathbf{m g ~ L}^{-\mathbf{1}}\right)$ \\
\hline $\mathrm{Cu}$ & 0.004 & 0.009 \\
$\mathrm{Ni}$ & 0.006 & 0.02 \\
$\mathrm{~Pb}$ & 0.0003 & 0.0004 \\
$\mathrm{~V}$ & 0.006 & 0.01 \\
$\mathrm{Zn}$ & 0.04 & 0.1 \\
**IDL = Instrument Detection Limit \\
**MDL = Method Detection Limit
\end{tabular}


Table S3. Maximum Contaminant Level (MCL) and different standards for exposure limits set by USEPA for Cr, Cu, Fe, Mn and Zn. Additionally, average concentrations of these 5 metals in natural soils (without known anthropogenic additions) are also provided for comparison with soil samples collected along the East Fork Jemez river ranges for this study.

\begin{tabular}{|c|c|c|c|c|c|c|c|}
\hline Element & $\begin{array}{l}\text { Drinking } \\
\text { water } \\
\text { standard- } \\
\text { Maximum } \\
\text { Contaminant } \\
\text { Level }(\mathrm{MCL}) \\
\left(\mu \mathrm{g} \mathrm{L}^{-1}\right)^{2}\end{array}$ & $\begin{array}{l}\text { Drinking } \\
\text { water } \\
\text { action level } \\
\left(\mu \mathrm{g} \mathrm{L}^{-1}\right)^{3}\end{array}$ & $\begin{array}{l}\text { Drinking } \\
\text { water } \\
\text { secondary } \\
\text { standard } \\
\left(\mu \mathrm{g} \mathrm{L}^{-1}\right)^{1}\end{array}$ & $\begin{array}{l}\text { Surface water } \\
\text { human health for } \\
\text { the consumption } \\
\text { of water + } \\
\text { organism }\left(\mu \mathrm{g} \mathrm{L}^{-1}\right)^{3}\end{array}$ & $\begin{array}{l}\text { Aquatic } \\
\text { Life } \\
\text { Freshwater } \\
\text { CMC Acute } \\
\text { Exposure } \\
\left(\mu \mathrm{g} \mathrm{L}^{-1}\right)\end{array}$ & $\begin{array}{l}\text { Aquatic Life } \\
\text { Freshwater } \\
\text { CCC } \\
\text { Chronic } \\
\text { Exposure } \\
\left(\mu \mathrm{g} \mathrm{L}^{-1}\right)\end{array}$ & $\begin{array}{l}\text { Average } \\
\text { concentrations of } \\
\text { metals in non- } \\
\text { anthropogenically } \\
\text { affected soils in the } \\
\text { US (mg kg-1) by } \\
\text { Burt et al. } 5^{5}\end{array}$ \\
\hline Chromium (III) & & & & & 570 & 74 & \\
\hline Chromium (total) & 100 & & & & & & 88.7 \\
\hline Chromium (VI) & & & & & 16 & 11 & \\
\hline Copper $(\mathrm{Cu})$ & & 1300 & & 1300 & $2^{4}$ & $1.3^{4}$ & 24.7 \\
\hline Iron $(\mathrm{Fe})$ & & & 300 & & & 1000 & 19000 \\
\hline Manganese (Mn) & & & 50 & 50 & & & 62.6 \\
\hline Zinc $(\mathrm{Zn})$ & & & 5000 & 7400 & 120 & 120 & 589 \\
\hline
\end{tabular}

\section{References}

(1) USEPA, Secondary Drinking Water Standards: Guidance for Nuisance Chemicals, accessed on Dec 22, 2017 at https://www.epa.gov/dwstandardsregulations/secondary-drinking-water-standards-guidance-nuisance-chemicals

(2) USEPA, National Primary Drinking Water Regulations, accessed on Dec 22, 2017 at https://www.epa.gov/ground-water-anddrinking-water/table-regulated-drinking-water-contaminants

(3) USEPA, National Recommended Water Quality Criteria - Human Health Criteria Table, accessed on Dec 22, 2017 at https://www.epa.gov/wqc/national-recommended-water-quality-criteria-human-health-criteria-table

(4) USEPA, Fact Sheet: Draft Estuarine/Marine Copper Aquatic Life Ambient Water Quality Criteria, accessed on Dec 22, 2017 at https://www.epa.gov/sites/production/files/2016-08/documents/copper-estuarine-marine-draft-factsheet.pdf

(5) Burt, R.; Wilson, M.; Mays, M.; Lee, C., Major and trace elements of selected pedons in the USA. J. Environ. Qual. 2003, 32, (6), 2109-2121. 
Table S4. Acid extractable elemental content $\left(\mathrm{mg} \mathrm{kg}^{-1}\right)$ for wood samples (Pine, Spruce, Aspen) at $60^{\circ} \mathrm{C}, 350^{\circ} \mathrm{C}$ and $550^{\circ} \mathrm{C}$. Data are presented as Mean \pm standard deviation.

Acid Extractable Elemental Content (mg kg-1)

\begin{tabular}{|c|c|c|c|c|c|c|c|c|c|c|c|c|}
\hline \multicolumn{13}{|c|}{ Temperature: $550^{\circ} \mathrm{C}$} \\
\hline Sample & Al & $\mathbf{C a}$ & $\mathbf{C r}$ & $\mathrm{Cu}$ & $\mathbf{F e}$ & $\mathbf{K}$ & Mg & Mn & $\mathrm{Ni}$ & $\mathbf{S i}$ & $\mathbf{S r}$ & $\mathbf{Z n}$ \\
\hline Pine & $\begin{array}{c}4138.40 \\
\pm \\
100.17\end{array}$ & $\begin{array}{c}181967.73 \\
\pm \\
6195.55\end{array}$ & $\begin{array}{c}476.16 \\
\pm \\
9.12\end{array}$ & $\begin{array}{c}2765.07 \\
\pm \\
302.26\end{array}$ & $\begin{array}{c}5050.52 \\
\pm \\
767.95\end{array}$ & $\begin{array}{c}78075.67 \\
\pm \\
1781.05\end{array}$ & $\begin{array}{c}27881.15 \\
\pm \\
35.82\end{array}$ & $\begin{array}{c}1575.62 \\
\pm \\
14.15\end{array}$ & $\begin{array}{c}803.60 \\
\pm \\
22.81\end{array}$ & $\begin{array}{c}814.26 \\
\pm \\
93.11\end{array}$ & $\begin{array}{c}505.93 \\
\pm \\
1.75\end{array}$ & $\begin{array}{c}938.27 \\
\pm \\
4.94\end{array}$ \\
\hline Spruce & $\begin{array}{c}4734.25 \\
\stackrel{ \pm}{64.55}\end{array}$ & $\begin{array}{c}164204.50 \\
\pm \stackrel{ \pm}{3} .07\end{array}$ & $\begin{array}{c}81.50 \\
\pm \\
1.07\end{array}$ & $\begin{array}{c}71.88 \\
\pm \\
1.59\end{array}$ & $\begin{array}{c}4154.38 \\
\pm \\
40.74\end{array}$ & $\begin{array}{c}33847.64 \\
\pm \\
628.85\end{array}$ & $\begin{array}{c}9807.35 \\
\pm \\
106.4\end{array}$ & $\begin{array}{c}3933.69 \\
\pm \\
41.92\end{array}$ & $\begin{array}{c}242.56 \\
\pm \\
2.91\end{array}$ & $\begin{array}{c}334.93 \\
\pm \\
29.36\end{array}$ & $\begin{array}{c}551.96 \\
\frac{ \pm}{6.25}\end{array}$ & $\begin{array}{c}590.30 \\
\pm \\
7.67\end{array}$ \\
\hline Aspen & $\begin{array}{c}177.41 \\
\pm \\
3.19\end{array}$ & $\begin{array}{c}307080.02 \\
\pm \frac{1}{4896.33}\end{array}$ & $\begin{array}{c}12.91 \\
\pm \\
2.01\end{array}$ & $\begin{array}{c}72.42 \\
\pm \\
1.62\end{array}$ & $\begin{array}{c}238.57 \\
\pm \frac{1}{4} .5\end{array}$ & $\begin{array}{c}47800.02 \\
\pm \stackrel{ \pm}{7} \\
728.85\end{array}$ & $\begin{array}{c}14193.24 \\
\pm \stackrel{ \pm}{129.61}\end{array}$ & $\begin{array}{c}175.14 \\
\pm \frac{1}{74}\end{array}$ & $\begin{array}{c}277.82 \\
\pm \\
1.64\end{array}$ & $\begin{array}{c}289.68 \\
\pm \\
1.58\end{array}$ & $\begin{array}{c}1372.46 \\
\pm \\
15.07\end{array}$ & $\begin{array}{c}1209.62 \\
\pm \stackrel{5}{12.29}\end{array}$ \\
\hline \multicolumn{13}{|c|}{ Temperature: $350^{\circ} \mathrm{C}$} \\
\hline Pine & $\begin{array}{c}2384.54 \\
\pm \\
96.48\end{array}$ & $\begin{array}{c}122157.57 \\
\pm \\
4502.43\end{array}$ & $\begin{array}{c}543.31 \\
\pm \\
123.69\end{array}$ & $\begin{array}{c}4996.51 \\
\pm \\
261.96\end{array}$ & $\begin{array}{c}4151.65 \\
\pm \\
441.79\end{array}$ & $\begin{array}{c}55823.72 \\
\pm \\
2122.64\end{array}$ & $\begin{array}{c}19205.62 \\
\pm \\
747.69\end{array}$ & $\begin{array}{c}1179.05 \\
\pm \\
61.36\end{array}$ & $\begin{array}{c}524.65 \\
\pm \\
101.22\end{array}$ & $\begin{array}{c}310.14 \\
\pm \\
18.17\end{array}$ & $\begin{array}{c}332.28 \\
\pm \\
12.89\end{array}$ & $\begin{array}{c}638.32 \\
\pm \\
23.33\end{array}$ \\
\hline Spruce & $\begin{array}{c}4477.69 \\
\pm \frac{\overline{5}}{17.93}\end{array}$ & $\begin{array}{c}186287.82 \\
\pm \\
5459.71\end{array}$ & $\begin{array}{c}112.24 \\
\pm \\
3.06\end{array}$ & $\begin{array}{c}81.47 \\
\pm \\
5.42\end{array}$ & $\begin{array}{c}3598.13 \\
\pm \\
908.11\end{array}$ & $\begin{array}{c}37261.72 \\
\pm \\
1050.50\end{array}$ & $\begin{array}{c}6168.71 \\
\pm \\
48.12\end{array}$ & $\begin{array}{c}4760.57 \\
\pm \frac{1}{5} .24\end{array}$ & $\begin{array}{c}266.93 \\
\pm \\
3.04\end{array}$ & $\begin{array}{c}322.53 \\
\pm \\
23.09\end{array}$ & $\begin{array}{c}646.79 \\
\pm \\
27.32\end{array}$ & $\begin{array}{c}799.14 \\
\pm \\
36.21\end{array}$ \\
\hline Aspen & $\begin{array}{c}184.81 \\
\pm \\
1.67\end{array}$ & $\begin{array}{c}294197.49 \\
\pm \\
1343.51\end{array}$ & $\begin{array}{c}11.83 \\
\pm \\
0.13\end{array}$ & $\begin{array}{c}62.89 \\
\pm \\
0.60\end{array}$ & $\begin{array}{c}225.13 \\
\pm \\
4.72\end{array}$ & $\begin{array}{c}45153.30 \\
\pm \\
242.64\end{array}$ & $\begin{array}{c}13275.79 \\
\pm \\
73.52\end{array}$ & $\begin{array}{c}182.36 \\
\pm \\
1.08\end{array}$ & $\begin{array}{c}264.34 \\
\pm \\
3.52\end{array}$ & $\begin{array}{c}241.02 \\
\pm \\
5.76\end{array}$ & $\begin{array}{c}1390.40 \\
\pm \\
3.89\end{array}$ & $\begin{array}{c}1206.46 \\
\pm \\
8.47\end{array}$ \\
\hline \multicolumn{13}{|c|}{ Temperature: $60^{\circ} \mathrm{C}$} \\
\hline Pine & $\begin{array}{c}91.1 \\
\pm \\
3.05\end{array}$ & $\begin{array}{c}9364.2 \\
\pm \\
220.03\end{array}$ & $\begin{array}{c}4.97 \\
\pm \\
1.29\end{array}$ & $\begin{array}{c}58.2 \\
\pm \\
18.24\end{array}$ & $\begin{array}{c}114.7 \\
\pm \\
45.69\end{array}$ & $\begin{array}{c}8696.5 \\
\pm \\
35.69\end{array}$ & $\begin{array}{c}466.3 \\
\pm \\
8 . \overline{4} 7\end{array}$ & $\begin{array}{c}59.6 \\
\pm \\
2.81\end{array}$ & $\begin{array}{c}6.1 \\
\pm \\
0.25\end{array}$ & $\begin{array}{c}202.8 \\
\pm \\
11.56\end{array}$ & $\begin{array}{c}13.1 \\
\pm \\
0.61\end{array}$ & $\begin{array}{c}23.3 \\
\pm \\
1.81\end{array}$ \\
\hline Spruce & $\begin{array}{c}131.5 \\
\pm \\
3.32\end{array}$ & 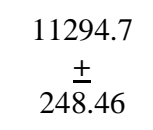 & $\begin{array}{c}12.9 \\
\pm \\
0.46\end{array}$ & $\begin{array}{c}4.6 \\
\pm \\
0.31\end{array}$ & $\begin{array}{c}198.9 \\
\pm \\
7.93\end{array}$ & $\begin{array}{c}8628.5 \\
\pm \\
28.68\end{array}$ & $\begin{array}{c}419.1 \\
\pm \\
15.13\end{array}$ & $\begin{array}{c}185.1 \\
\pm \\
6.5\end{array}$ & $\begin{array}{c}12.5 \\
\pm \\
0.9\end{array}$ & $\begin{array}{c}258.8 \\
\pm \\
1.67\end{array}$ & $\begin{array}{c}24.3 \\
\pm \\
0.61\end{array}$ & $\begin{array}{c}33.2 \\
\pm \\
0.4\end{array}$ \\
\hline Aspen & $\begin{array}{l}22.2 \\
\pm \\
1.15\end{array}$ & $\begin{array}{c}22359.3 \\
\pm \frac{ \pm}{5} \\
561\end{array}$ & $\begin{array}{c}5.1 \\
\pm \\
0.03\end{array}$ & $\begin{array}{c}5.7 \\
\pm \\
0.88\end{array}$ & $\begin{array}{c}22.4 \\
\pm \\
8.53\end{array}$ & $\begin{array}{c}9709.04 \\
\pm \\
25.86\end{array}$ & $\begin{array}{c}858.5 \\
\pm \\
4.22\end{array}$ & $\begin{array}{c}10.6 \\
\pm \\
0.15\end{array}$ & $\begin{array}{c}17.9 \\
\pm \\
0.82\end{array}$ & $\begin{array}{c}23.7 \\
\pm \\
3.9\end{array}$ & $\begin{array}{c}86.8 \\
\pm \\
0.35\end{array}$ & $\begin{array}{c}78.6 \\
\pm \\
1.49\end{array}$ \\
\hline
\end{tabular}


Table S5. The Kruskal Wallis test was used to determine if significant differences exist (defined as $p$-value $<0.05$ ) between the tree species (Pine, Spruce, Aspen) at three temperatures $\left(60^{\circ} \mathrm{C}, 350^{\circ} \mathrm{C}\right.$ and $\left.550^{\circ} \mathrm{C}\right)$ with respect to acid extractable metal concentrations $\left(\log _{10}\right.$ transformed). Individual contribution of the metals was not considered here due to limited number of observations $(n=3)$ for each metal. No significant difference (highlighted, $p$-value $=0.4007>0.05$ ) was observed for Pine, Aspen and Spruce at $60^{\circ} \mathrm{C}$. The limitation of Kruskal Wallis test is that it does not specify which specific sample is contributing to the overall difference. To address this, Mann Whitney U test was done to do pairwise comparisons between the samples.

\begin{tabular}{llcc} 
& & \multicolumn{2}{c}{ Comparison between Pine, Spruce and Aspen at $60^{\circ} \mathrm{C}, 350^{\circ} \mathrm{C}$ and } \\
\cline { 3 - 4 } & & $\frac{550^{\circ} \mathrm{C}(\mathrm{n}=9)}{\chi^{2} \text { statistic }}$ & $\underline{\mathrm{p} \text {-value }}$ \\
\hline $\begin{array}{l}\text { acid extractable element } \\
\left(\log _{10} \text { transformed) }\right.\end{array}$ & 89.85 & $4.982 \times 10^{-4}$
\end{tabular}

Comparison between Pine 60, Spruce 60 and Aspen $60(n=3)$

$\begin{array}{lcc}\underline{\text { Data }} & \chi^{2} \text { statistic } & \text { p-value } \\ \begin{array}{l}\text { acid extractable element } \\ \left(\log _{10} \text { transformed }\right)\end{array} & 1.8293 & 0.4007\end{array}$

Comparison between Pine 350, Spruce 350 and Aspen $350(n=3)$

$\begin{array}{lcc}\underline{\text { Data }} & \chi^{2} \text { statistic } & \text { p-value } \\ \begin{array}{l}\text { acid extractable element } \\ \left(\log _{10} \text { transformed }\right)\end{array} & 8.1227 & 0.01723\end{array}$

Comparison between Pine 550, Spruce 550 and Aspen $550(n=3)$

\begin{tabular}{lcc}
$\underline{\text { Data }}$ & $\chi^{2}$ statistic & p-value \\
\hline $\begin{array}{l}\text { acid extractable element } \\
\left(\log _{10} \text { transformed }\right)\end{array}$ & 9.5225 & 0.00855
\end{tabular}


Table S6. The Wilcoxon rank sum test (Mann-Whitney U test) was used to do pairwise comparisons ( $\mathrm{n}=9$ samples, ${ }^{9} \mathrm{C}_{2}=36$ combinations of pairs) of tree species (Pine, Spruce, Aspen) at $60^{\circ} \mathrm{C}, 350^{\circ} \mathrm{C}$ and $550^{\circ} \mathrm{C}$ to test for significant differences (defined as $p<$ $0.05)$ in metal concentrations ( $\log _{10}$ transformed). Individual contribution of the metals was not considered here due to limited number of observations $(n=3)$ for each metal.

\begin{tabular}{clcccccrrr}
\hline Serial No. & Pair considered & Diff. & W & $\boldsymbol{p}$-value & Serial No. & Pair considered & Diff. & W & $\boldsymbol{p}$-value \\
\hline 1 & Aspen 350 - Aspen 60 & 1.078 & 990 & $1.20 \times 10^{-4}$ & 19 & Pine 60 - Aspen 60 & 0.164 & 726 & 0.383 \\
\hline 2 & Aspen 550 - Aspen 60 & 1.108 & 991 & $1.15 \times 10^{-4}$ & 20 & Spruce 60 - Aspen 60 & 0.331 & 765 & 0.190 \\
\hline 3 & Spruce 550 - Aspen 60 & 1.407 & 1043 & $8.87 \times 10^{-6}$ & 21 & Spruce 60 - Pine 60 & 0.642 & 690 & 0.103 \\
\hline 4 & Spruce 350 - Aspen 60 & 1.477 & 1053 & $5.22 \times 10^{-6}$ & 22 & Aspen 550 - Aspen 350 & 0.021 & 672 & 0.793 \\
\hline 5 & Pine 350 - Aspen 60 & 1.678 & 1080 & $1.18 \times 10^{-6}$ & 23 & Spruce 550 - Aspen 350 & 0.401 & 788 & 0.117 \\
\hline 6 & Pine 550 - Aspen 60 & 1.748 & 1101 & $3.47 \times 10^{-7}$ & 24 & Spruce 350 - Aspen 350 & 0.462 & 798 & 0.092 \\
\hline 7 & Aspen 350 - Pine 60 & 0.761 & 960 & $3.38 \times 10^{-4}$ & 25 & Pine 350 - Aspen 350 & 0.532 & 912 & $2.64 \times 10^{-3}$ \\
\hline 8 & Aspen 550 - Pine 60 & 0.780 & 967 & $2.43 \times 10^{-4}$ & 26 & Pine 550 - Aspen 350 & 0.634 & 927 & $1.45 \times 10^{-4}$ \\
\hline 9 & Spruce 550 - Pine 60 & 1.261 & 1043 & $3.67 \times 10^{-6}$ & 27 & Spruce 550 - Aspen 550 & 0.371 & 775 & 0.155 \\
\hline 10 & Spruce 350 - Pine 60 & 1.284 & 1042 & $3.91 \times 10^{-6}$ & 28 & Spruce 350 - Aspen 550 & 0.434 & 783 & 0.130 \\
\hline 11 & Pine 350 - Pine 60 & 1.413 & 1110 & $3.06 \times 10^{-8}$ & 29 & Pine 350 - Aspen 550 & 0.542 & 911 & $2.75 \times 10^{-3}$ \\
\hline 12 & Pine 550 - Pine 60 & 1.547 & 1133 & $4.36 \times 10^{-9}$ & 30 & Pine 550 - Aspen 550 & 0.651 & 927 & $1.45 \times 10^{-3}$ \\
\hline 13 & Aspen 350 - Spruce 60 & 0.774 & 903 & $3.73 \times 10^{-3}$ & 31 & Spruce 350 - Spruce 550 & 0.043 & 694 & 0.610 \\
\hline 14 & Aspen 550 - Spruce 60 & 0.777 & 910 & $2.86 \times 10^{-3}$ & 32 & Pine 350 - Spruce 550 & 0.140 & 738 & 0.316 \\
\hline 15 & Spruce 550 - Spruce 60 & 1.238 & 1008 & $2.91 \times 10^{-5}$ & 33 & Pine 550 - Spruce 550 & 0.324 & 783 & 0.130 \\
\hline 16 & Spruce 350 - Spruce 60 & 1.235 & 1008 & $2.91 \times 10^{-5}$ & 34 & Pine 350 - Spruce 350 & 0.150 & 713 & 0.470 \\
\hline 17 & Pine 350 - Spruce 60 & 1.339 & 1114 & $2.21 \times 10^{-8}$ & 35 & Pine 550 - Spruce 350 & 0.282 & 761 & 0.207 \\
\hline 18 & Pine 550 - Spruce 60 & 1.431 & 1134 & $3.99 \times 10^{-9}$ & 36 & Pine 550 - Pine 350 & 0.150 & 738 & 0.316 \\
\hline
\end{tabular}

$=p$-value $<0.05=$ Significant difference

$=p$-value $>0.05=$ No significant difference 
Table S7. Specific surface areas $\left(\mathrm{m}^{2} / \mathrm{g}\right)$ of the Pine, Spruce and Aspen ash samples measured by Brunauer-Emmett-Teller (BET) method.

\begin{tabular}{cc}
\hline Sample & BET Multipoint Surface Area $\left(\mathrm{m}^{2} / \mathrm{g}\right)$ \\
\hline Pine Ash $350^{\circ} \mathrm{C}$ & 36.91 \\
Pine Ash $550^{\circ} \mathrm{C}$ & 294.37 \\
Spruce $\operatorname{Ash} 350^{\circ} \mathrm{C}$ & 20.29 \\
Spruce $\operatorname{Ash} 550^{\circ} \mathrm{C}$ & 124.77 \\
Aspen $\operatorname{ash~} 350^{\circ} \mathrm{C}$ & 7.06 \\
Aspen $\operatorname{ash~} 550^{\circ} \mathrm{C}$ & 12.9 \\
\hline
\end{tabular}


Table S8. Elemental composition $(\mathrm{C}, \mathrm{H}, \mathrm{N}, \mathrm{O})$ and ratios of Pine, Spruce and Aspen samples at $60^{\circ} \mathrm{C}, 350^{\circ} \mathrm{C}$ and $550^{\circ} \mathrm{C}$. $\mathrm{H} / \mathrm{C}$ is the atomic ratio of hydrogen to carbon; $\mathrm{O} / \mathrm{C}$ is the atomic ratio of oxygen to carbon and $(\mathrm{O}+\mathrm{N}) / \mathrm{C}$ is the atomic ratio of the sum of nitrogen and oxygen to carbon.

Elemental composition

\begin{tabular}{lccccccc} 
& \multicolumn{3}{c}{} & & & & Molar \\
Sample & $\mathrm{C}(\%)$ & $\mathrm{H}(\%)$ & $\mathrm{N}(\%)$ & $\mathrm{O}(\%)$ & $\mathrm{H} / \mathrm{C}$ & $\begin{array}{c}\text { Molar } \\
\mathrm{O} / \mathrm{C}\end{array}$ & $\begin{array}{c}\text { Molar } \\
(\mathrm{O}+\mathrm{N}) / \mathrm{C}\end{array}$ \\
\hline Pine $60^{\circ} \mathrm{C}$ & 52.1 & 6.91 & 0.5 & 37.7 & 1.589 & 0.542 & 0.549 \\
Spruce $60^{\circ} \mathrm{C}$ & 50.3 & 6.86 & 0.3 & 41.2 & 1.638 & 0.614 & 0.619 \\
Aspen $60^{\circ} \mathrm{C}$ & 51.1 & 6.87 & 0.4 & 39.4 & 1.615 & 0.578 & 0.585 \\
\hline Pine $350^{\circ} \mathrm{C}$ & 31.8 & 1.10 & 2.4 & 26.9 & 0.414 & 0.634 & 0.699 \\
Spruce $350^{\circ} \mathrm{C}$ & 15.0 & 0.48 & 0.7 & 21.5 & 0.384 & 1.078 & 1.115 \\
Aspen 350 $\mathrm{C}$ & 14.0 & 0.42 & 0.3 & 28.6 & 0.361 & 1.537 & 1.555 \\
\hline Pine 550 ${ }^{\circ} \mathrm{C}$ & 16.3 & 0.57 & 0.4 & 21.8 & 0.421 & 0.998 & 1.018 \\
Spruce 550 & 25.3 & 0.62 & 0.4 & 19.7 & 0.294 & 0.583 & 0.598 \\
Aspen 550 $\mathrm{C}$ & 6.1 & 0.26 & 0.4 & 27.1 & 0.513 & 3.326 & 3.379 \\
\hline
\end{tabular}


Table S9. Atomic content for the unreacted and reacted $350^{\circ} \mathrm{C}$ pine ash as determined by X-ray photoelectron spectroscopy (XPS) survey scan.

\begin{tabular}{llll} 
& \multicolumn{3}{c}{$\%$ Atomic Content } \\
\cline { 2 - 4 } Sample & $\mathrm{C} 1 \mathrm{~s}$ & $\mathrm{O} 1 \mathrm{~s}$ & $\mathrm{Cu} 2 \mathrm{p}$ \\
\hline Unreacted $350^{\circ} \mathrm{C}$ pine ash & 66.2 & 33.8 & $\mathrm{BDL}^{1}$ \\
Reacted $350^{\circ} \mathrm{C}$ pine ash & 73.2 & 26.7 & 0.11 \\
\hline & \multicolumn{3}{c}{${ }^{1}$ Below detection limit }
\end{tabular}




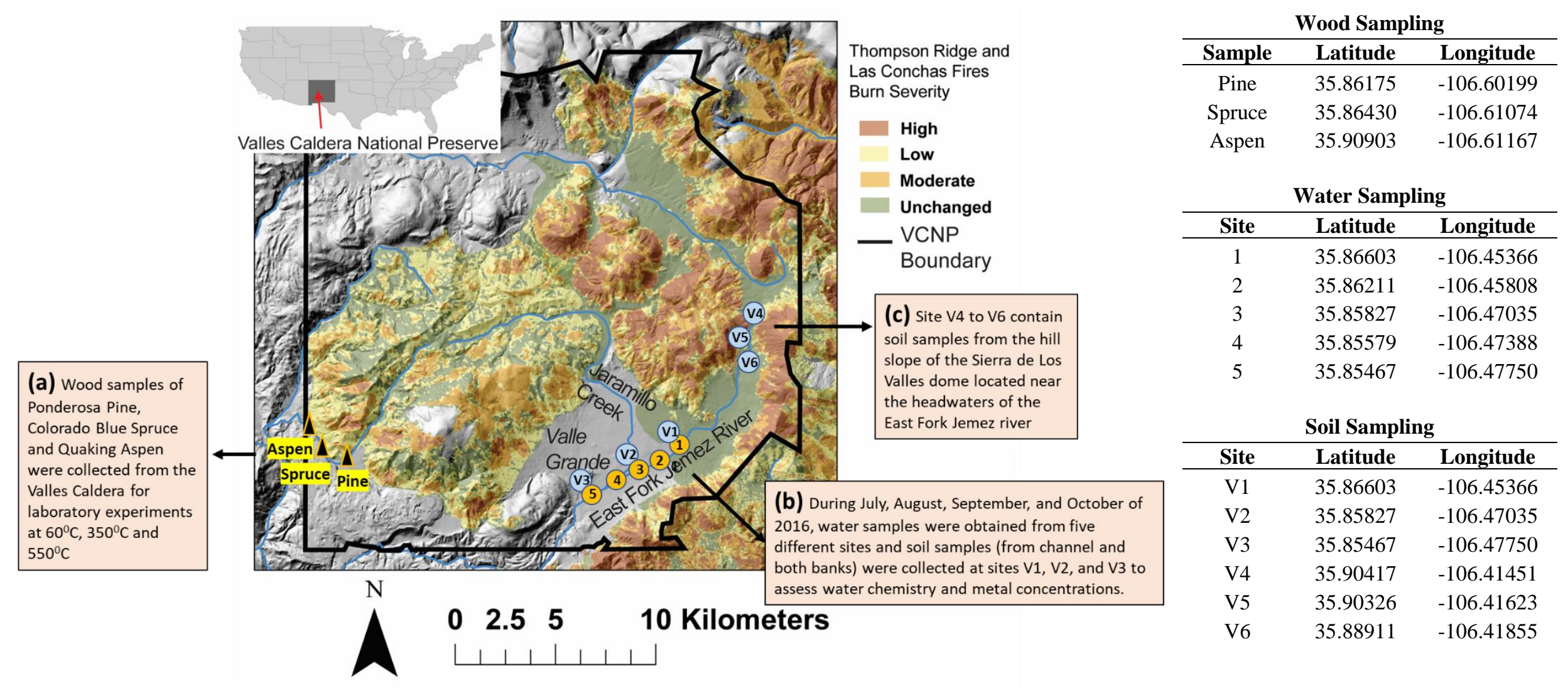

Figure S1. Map showing the sampling locations for (a) wood, (b) water and soil and (c) soil samples in Valles Caldera. The co-ordinates of the sampling locations are shown beside the map. This site map is adapted from the map published in a previous study by Cerrato et al. ${ }^{23}$

\section{Reference}

(1) Cerrato, J. M.; Blake, J. M.; Hirani, C.; Clark, A. L.; Ali, A.-M. S.; Artyushkova, K.; Peterson, E.; Bixby, R. J., Wildfires and water chemistry: effect of metals associated with wood ash. Environ. Sci. Process. Impacts. 2016, 18, (8), $1078-1089$. 


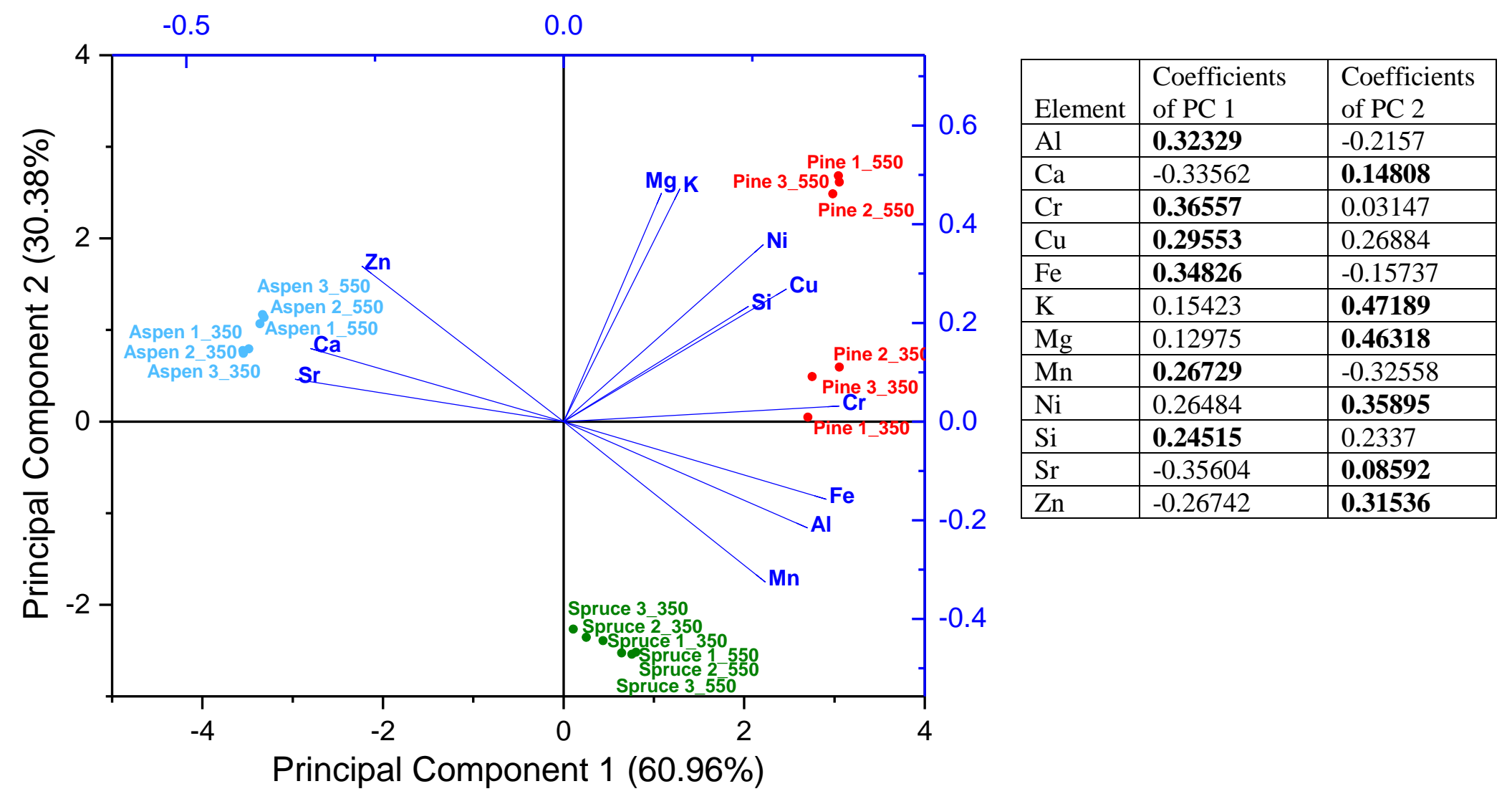

Figure S2. Principal component analysis was run on metal concentrations for $350^{\circ} \mathrm{C}$ and $550^{\circ} \mathrm{C}$ triplicate measurements of ash samples (Pine, Spruce, Aspen). The first two principal components explained $91.34 \%$ of the total variance. The metals such as $\mathrm{Al}, \mathrm{Cr}, \mathrm{Cu}, \mathrm{Fe}$, $\mathrm{Mn}$ and Si showed high positive loadings on PC 1; and PC 2 showed high positive loadings for the major elements (Ca, K, Mg) and metals such as $\mathrm{Ni}, \mathrm{Sr}$ and $\mathrm{Zn}$. Coefficients of the metals on the principal components are shown in the table. The figure also shows the component scores of the Pine, Spruce and Aspen ash samples. $350^{\circ} \mathrm{C}$ and $550^{\circ} \mathrm{C}$ Pine ash samples had positive scores on the both the principal components. 
(a)

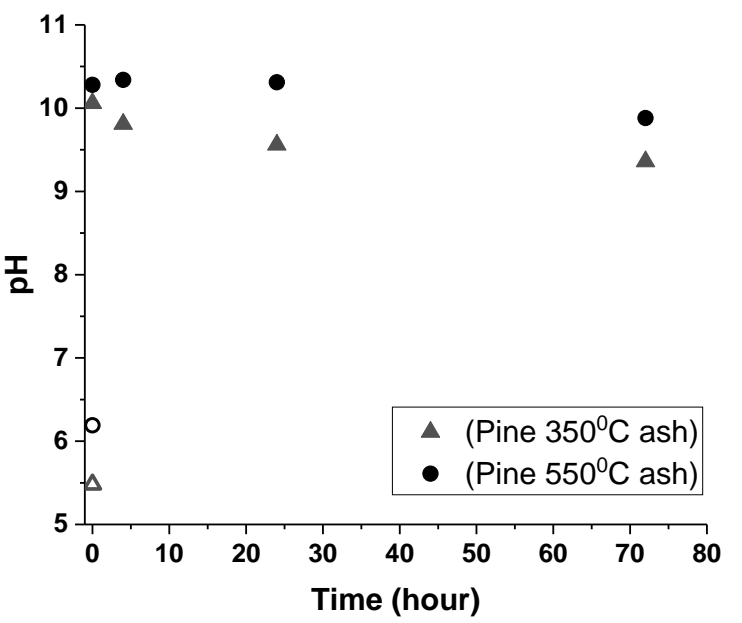

(b)

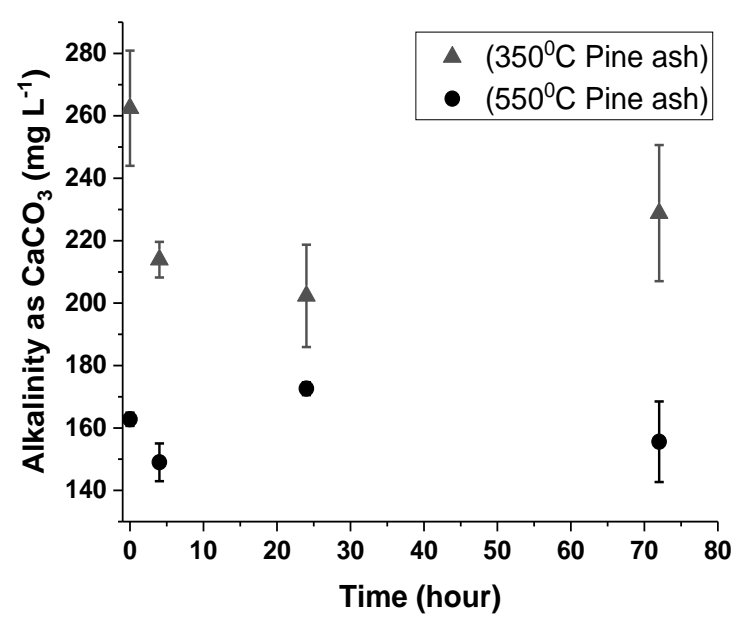

Figure S3. $\mathrm{pH}$ and alkalinity measured at 0, 4, 24 and 72 hours are shown in figure (a) and (b) respectively. In figure (a), the open symbols represent the $\mathrm{pH}$ of $18 \mathrm{M} \Omega$ water. 


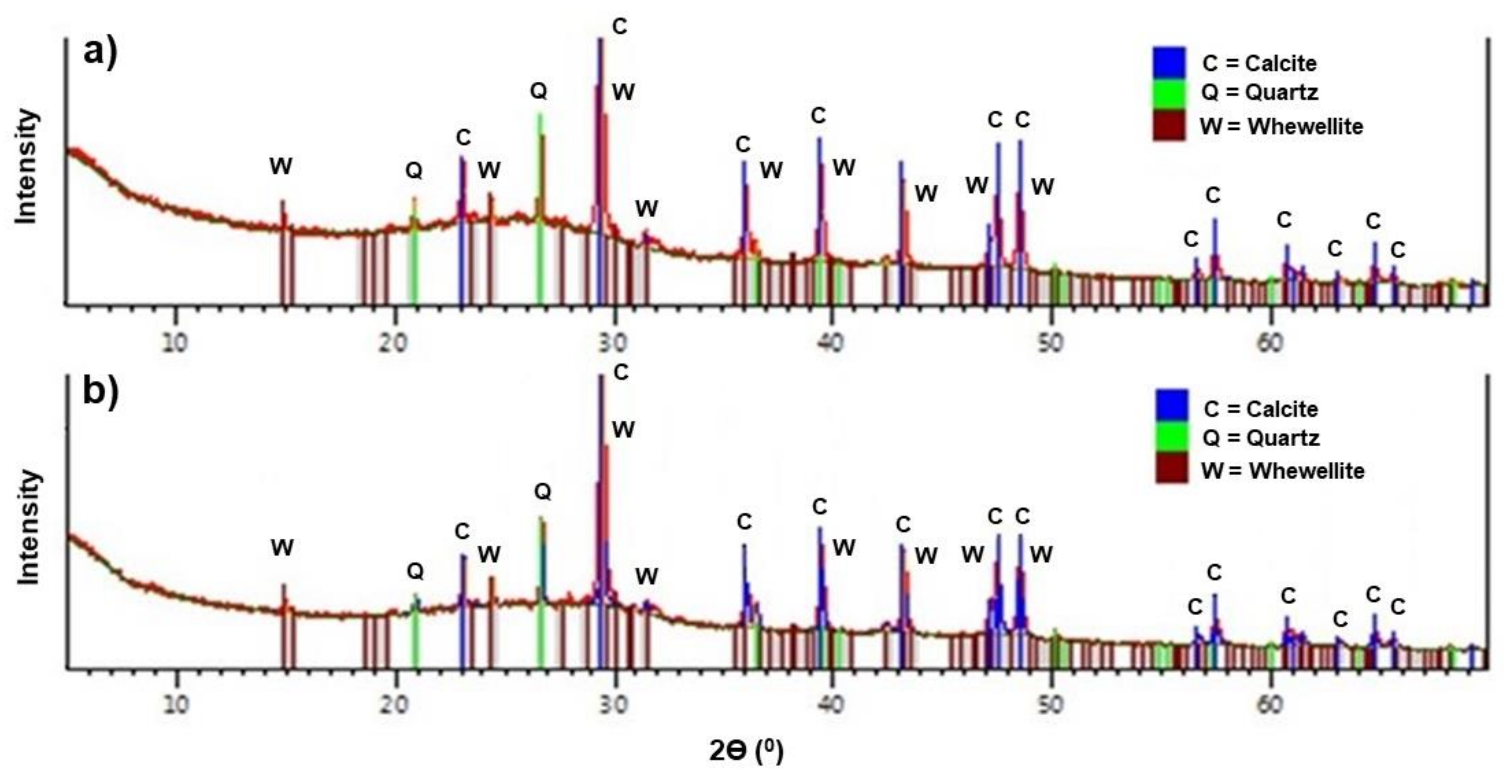

\begin{tabular}{lcc} 
Compound Name & $\begin{array}{c}\text { Unreacted Ash } \\
\text { (atomic wt.\%) }\end{array}$ & $\begin{array}{c}\text { Reacted Ash } \\
\text { (atomic wt.\%) }\end{array}$ \\
\hline Calcite $\left(\mathrm{CaCO}_{3}\right)$ & $79 \%$ & $78 \%$ \\
Quartz $\left(\mathrm{SiO}_{2}\right)$ & $12 \%$ & $11 \%$ \\
Whewellite $\left(\mathrm{Ca}\left(\mathrm{C}_{2} \mathrm{O}_{4}\right) \cdot \mathrm{H}_{2} \mathrm{O}\right)$ & $9 \%$ & $11 \%$
\end{tabular}

Figure S4. XRD patterns of the (a) reacted and the (b) unreacted $350^{\circ} \mathrm{C}$ Pine ash sample from the batch sorption experiments with $\mathrm{Cu}(\mathrm{II})$. The two samples are very similar in terms of crystalline composition which is predominantly calcite (78-79\%) with lesser amounts of quartz (11-12\%) and whewellite $(9-11 \%)$. 
(a)

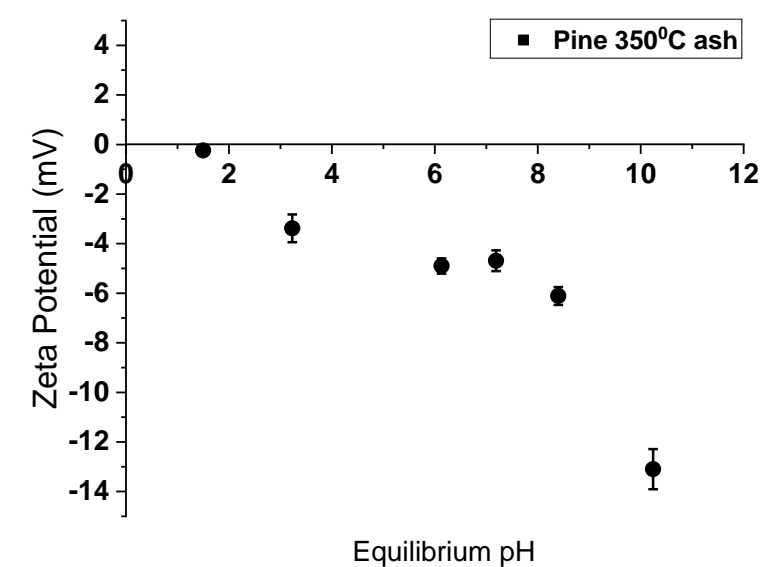

(b)

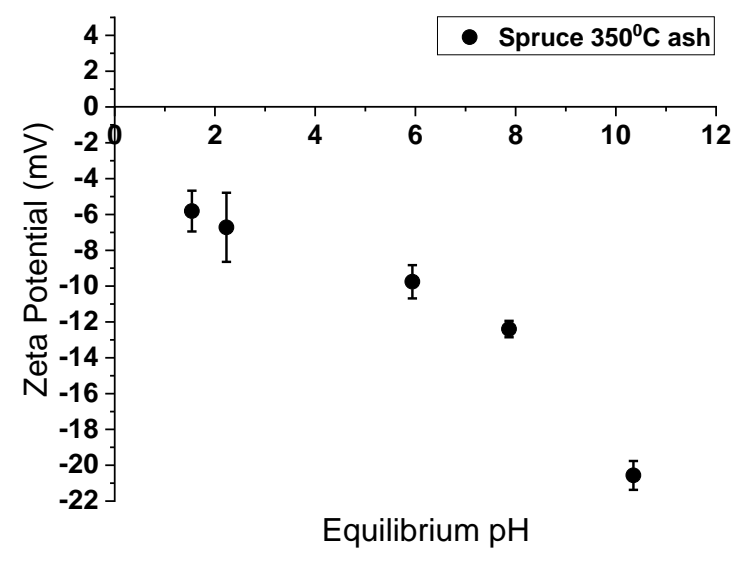

(c)

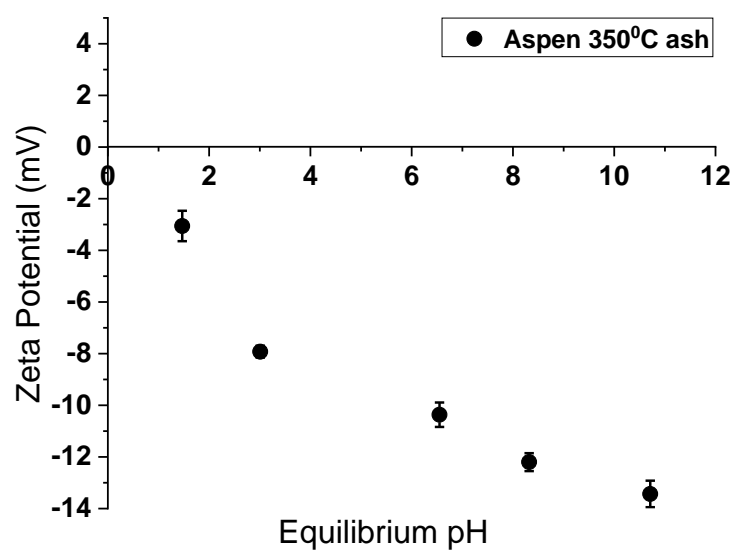

Figure S5. Zeta Potential (mV) measurements of (a) Pine $350^{\circ} \mathrm{C}$ ash, (b) Spruce $350^{\circ} \mathrm{C}$ ash and (c) Aspen $350^{\circ} \mathrm{C}$ ash in different solution $\mathrm{pH}$ values. The reported values are the average of three measurements. 

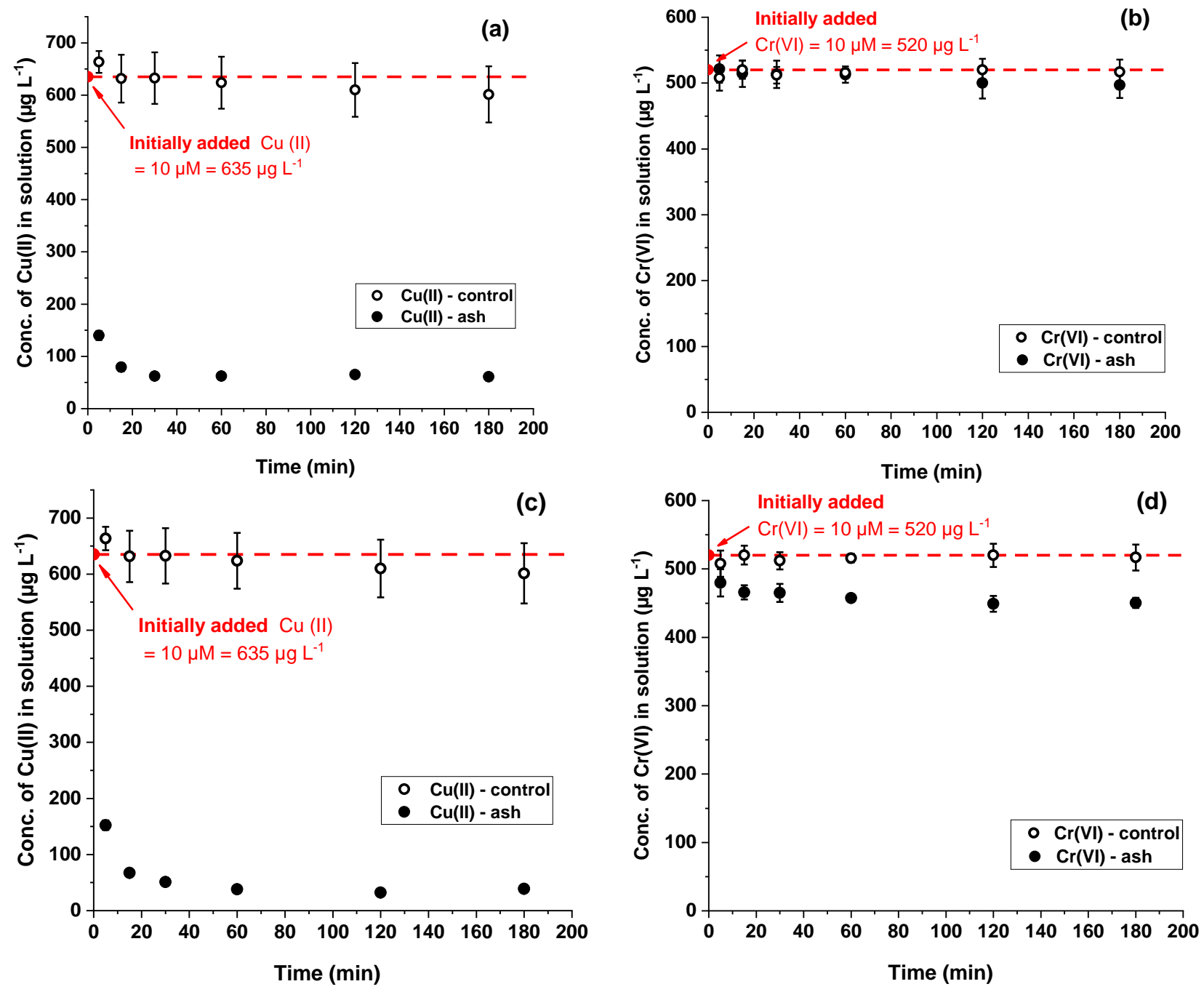

Figure S6. Results from the metal sorption experiments ( $\mathrm{n}=3$, sampling interval $=5 \mathrm{~min}, 15 \mathrm{~min}$, $30 \mathrm{~min}, 1 \mathrm{hr}, 2 \mathrm{hrs}$ and $3 \mathrm{hrs}$ ) conducted by reacting $10 \mu \mathrm{M}$ of (a) $\mathrm{Cu}(\mathrm{II})$ and (b) $\mathrm{Cr}$ (VI) separately in a solution containing $0.1 \mathrm{~g}$ of $350^{\circ} \mathrm{C}$ Spruce ash with $50 \mathrm{~mL}$ of $18 \mathrm{M} \Omega$ water. Figures (c) and (d) show the same analysis with Aspen ash. Results from the control experiments without the ash are included in all the figures. 

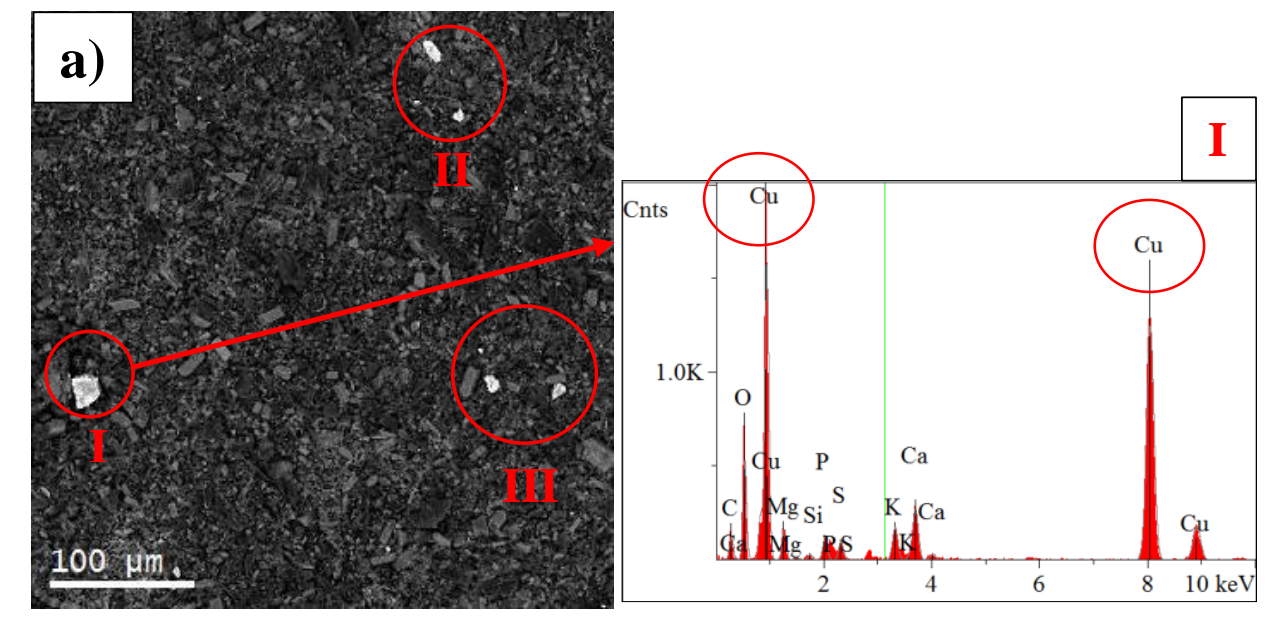

$\mathrm{kV} 20.0$

Takeoff Angle $35.0^{\circ}$ Elapsed Livetime 30.0

\begin{tabular}{|c|c|c|c|c|c|c|}
\hline Elt. & Line & $\begin{array}{r}\text { Intensity } \\
(\mathrm{c} / \mathrm{s})\end{array}$ & Conc & Units & $\begin{array}{r}\text { Error } \\
2 \sigma^{*}\end{array}$ & $\begin{array}{r}\text { MDL } \\
3 \sigma\end{array}$ \\
\hline $\mathrm{C}$ & $\mathrm{Ka}$ & 36.11 & 7.161 & wt.\% & 0.584 & 0.597 \\
\hline $\mathrm{O}$ & $\mathrm{Ka}$ & 151.37 & 12.566 & wt. $\%$ & 0.399 & 0.217 \\
\hline $\mathrm{Mg}$ & $\mathrm{Ka}$ & 53.62 & 2.914 & wt.\% & 0.189 & 0.185 \\
\hline $\mathrm{Al}$ & $\mathrm{Ka}$ & 4.88 & 0.212 & wt. $\%$ & 0.117 & 0.170 \\
\hline $\mathrm{Si}$ & $\mathrm{Ka}$ & 10.29 & 0.359 & wt. $\%$ & 0.103 & 0.144 \\
\hline $\mathrm{P}$ & $\mathrm{Ka}$ & 43.42 & 1.342 & wt.\% & 0.117 & 0.139 \\
\hline$S$ & $\mathrm{Ka}$ & 36.71 & 0.984 & wt.\% & $\begin{array}{l}0.101 \\
\end{array}$ & 0.125 \\
\hline $\mathrm{K}$ & $\mathrm{Ka}$ & 71.77 & 1.867 & wt. $\%$ & 0.115 & 0.125 \\
\hline $\mathrm{Ca}$ & $\mathrm{Ka}$ & 114.96 & 3.089 & wt. $\%$ & 0.133 & 0.124 \\
\hline \multirow[t]{2}{*}{$\mathrm{Cu}$} & $\mathrm{Ka}$ & 715.75 & 69.507 & wt. $\%$ & 0.973 & 0.332 \\
\hline & & Total & 100.000 & wt.\% & & \\
\hline
\end{tabular}
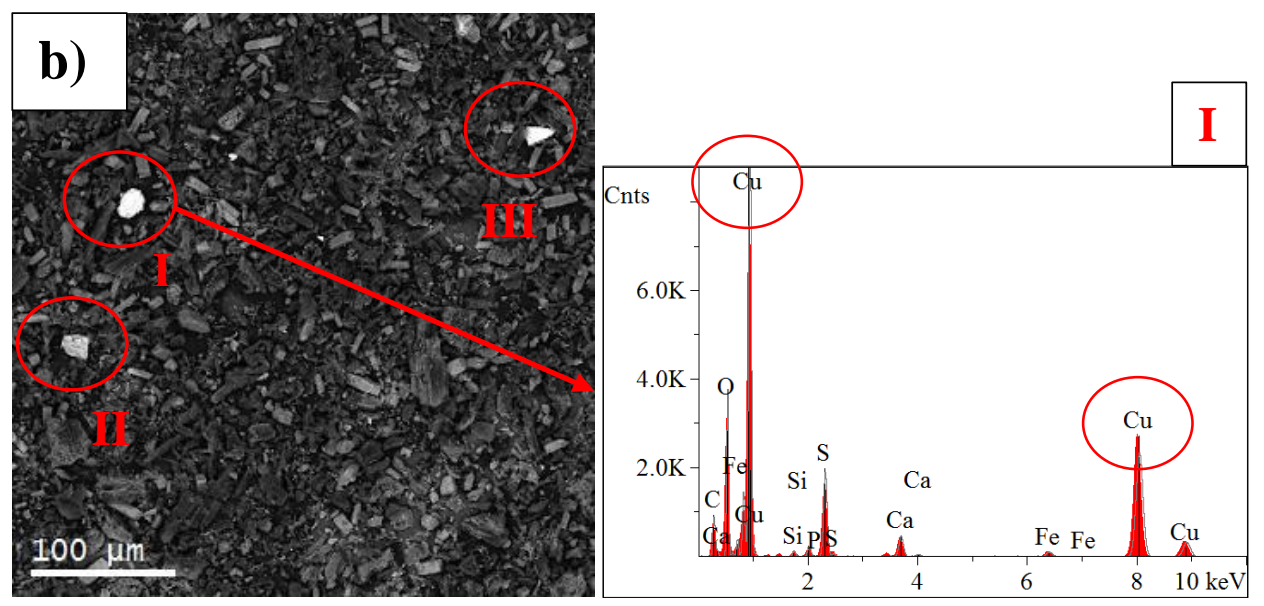

$\mathrm{kV} 20.0$

Takeoff Angle $35.0^{\circ}$

Elapsed Livetime 30.0

\begin{tabular}{|c|c|c|c|c|c|c|}
\hline Elt. & Line & $\begin{array}{l}\text { Intensity } \\
(\mathrm{c} / \mathrm{s})\end{array}$ & Conc & Units & $\begin{array}{l}\text { Error } \\
2 \sigma^{*}\end{array}$ & $\begin{array}{l}\text { MDL } \\
3 \sigma\end{array}$ \\
\hline C & $\mathrm{Ka}$ & 100.62 & 21.423 & wt. $\%$ & 0.662 & 0.415 \\
\hline $\mathrm{O}$ & $\mathrm{Ka}$ & 349.71 & 1.326 & wt. $\%$ & 0.020 & 0.006 \\
\hline $\mathrm{Si}$ & $\mathrm{Ka}$ & 19.73 & 0.588 & wt. $\%$ & 0.087 & 0.120 \\
\hline $\mathrm{P}$ & $\mathrm{Ka}$ & 35.91 & 0.959 & wt. $\%$ & 0.084 & 0.108 \\
\hline$S$ & $\mathrm{Ka}$ & 324.25 & 7.659 & wt.\% & 0.135 & 0.094 \\
\hline $\mathrm{Ca}$ & $\mathrm{Ka}$ & 97.24 & 3.322 & wt.\% & 0.132 & 0.140 \\
\hline $\mathrm{Fe}$ & $\mathrm{Ka}$ & 29.62 & 1.173 & wt. $\%$ & 0.102 & 0.124 \\
\hline \multirow[t]{2}{*}{$\mathrm{Cu}$} & $\mathrm{Ka}$ & 736.98 & 63.551 & wt.\% & 0.680 & 0.238 \\
\hline & & Total & 100.000 & wt. $\%$ & & \\
\hline
\end{tabular}

Figure S7. SEM images of the (a) unreacted and the (b) reacted $350^{\circ} \mathrm{C}$ Pine ash from the batch sorption experiments with Cu(II). EDS spectrum from a $\mathrm{Cu}$ grain on both the ash samples shows presence of $\mathrm{Cu}$ peaks. The atomic wt.\% distribution for the respective spectrum is also shown for a specific $\mathrm{Cu}$ grain highlighted in red circle. 
(a)
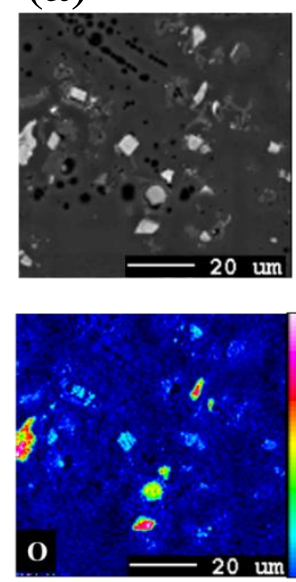
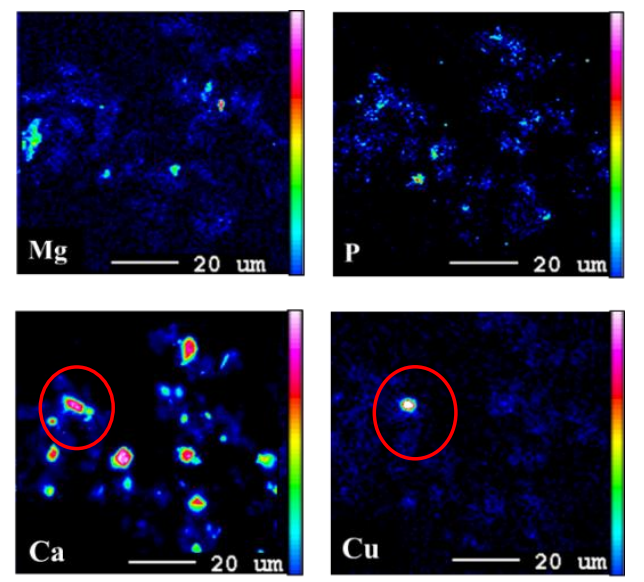

(c) Microprobe mapping of the mineralized Ca region [red circled in figure (a)] of the reacted ash
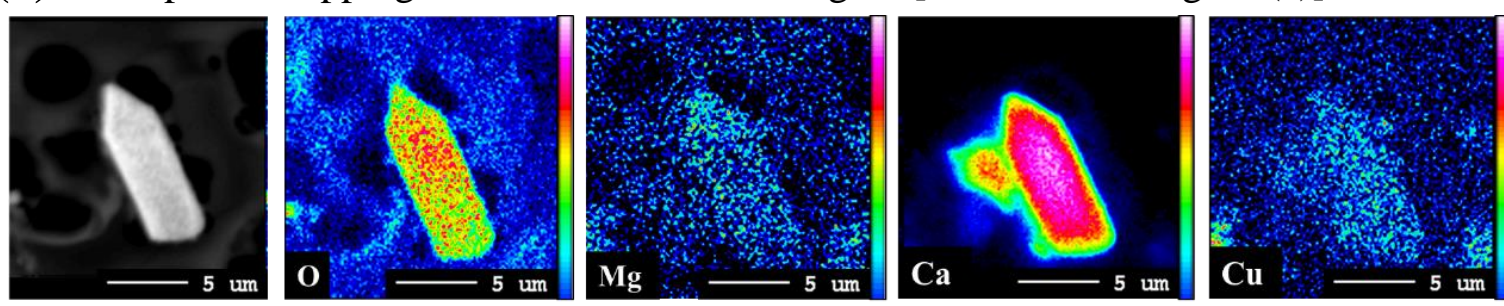

(d)

Average of 7 reference lines (Reacted sample)

Average of 7 reference

lines (Unreacted

K $(\mathbf{w t} \%)$

$\mathrm{Ca}(\mathrm{wt} \%) \quad \mathrm{Mg}(\mathrm{wt} \%) \quad \mathrm{Cu}$ wt $\%$

$\mathrm{Si}(\mathrm{wt} \%)$
0.006

S (wt\%)
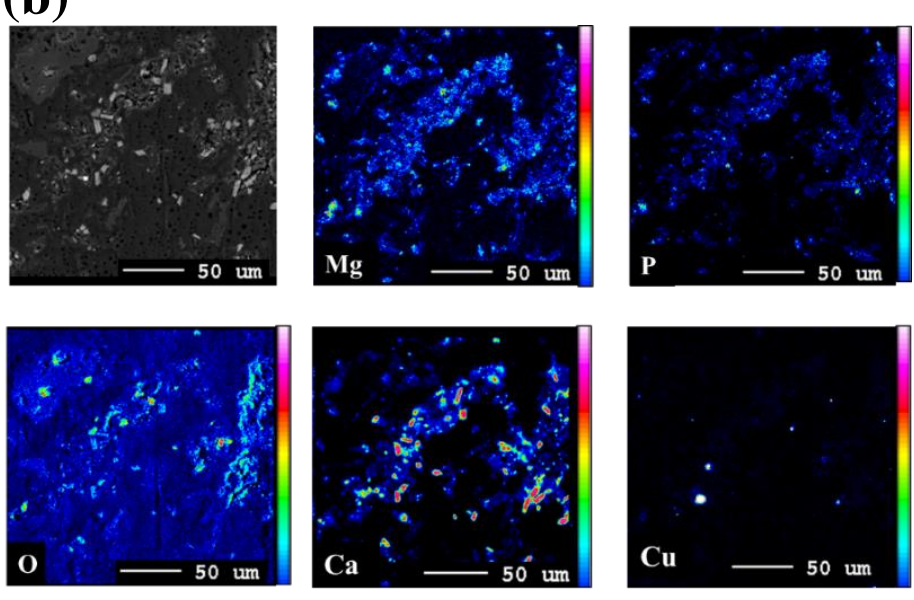

sample)

0.137

17.557

0.014

$\mathrm{BDL}^{*}$

BDL

0.013

Figure S8. Microprobe mapping of $\mathrm{Mg}, \mathrm{P}, \mathrm{O}, \mathrm{Ca}$ and $\mathrm{Cu}$ on the (a) reacted and (b) unreacted $350^{\circ} \mathrm{C} \mathrm{Pine}$ ash. Microprobe analysis showed presence of low level of detectable $\mathrm{Cu}$ associated with mineralized $\mathrm{Ca}$ in the reacted ash, shown in figure (c). In table (d), the wt\% of the elements associated with the mineralized Ca region is shown. At $95 \%$ confidence level, the $\mathrm{Cu}$ in the reacted sample is detectable at $0.012 \mathrm{wt} \%$ but below detection limit in the unreacted sample. Detection limit for $\mathrm{Cu}$ at $95 \%$ confidence level was $0.009 \mathrm{wt} \%$. 

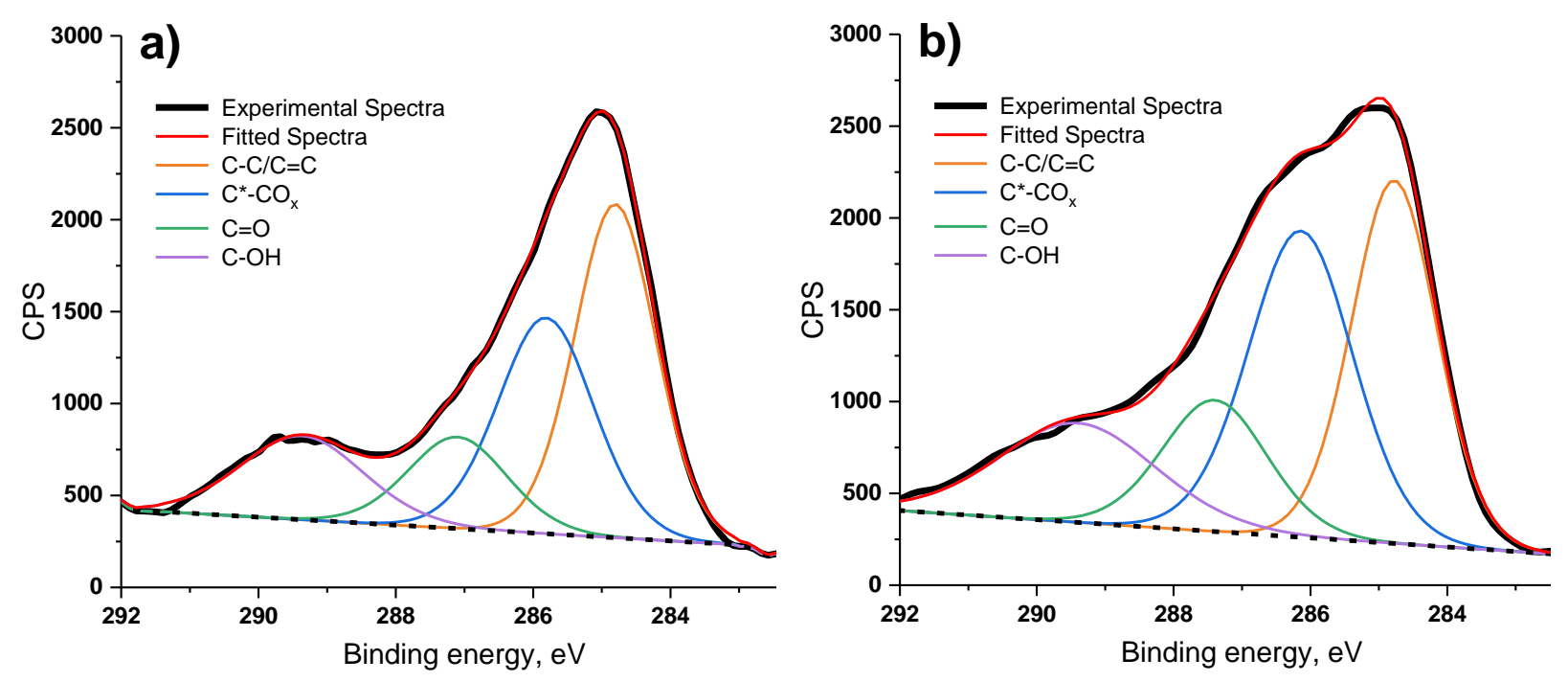

c) Percentages of surface carbon bonds determined from curve fitting of $\mathrm{C} 1 \mathrm{~s}$ high resolution XPS spectra

$\mathrm{C}-\mathrm{C} \% \quad \mathrm{C} *-\mathrm{CO}_{\mathrm{x}} \% \quad \mathrm{C}=\mathrm{O} \% \quad \mathrm{C}-\mathrm{OH} \%$

\begin{tabular}{lcccc}
\hline Binding energy, eV & $\mathbf{2 8 5}$ & $\mathbf{2 8 5 . 6}$ & $\mathbf{2 8 7 . 5}$ & $\mathbf{2 8 9 . 5}$ \\
\hline Untreated ash & 35.3 & 16.8 & 4.7 & 9.4 \\
Reacted ash & 25.3 & 24.2 & 11.9 & 11.8 \\
\hline
\end{tabular}

Figure S9. XPS high resolution C 1s spectra for the (a) Unreacted $350^{\circ} \mathrm{C}$ Pine ash sample and (b) the reacted $350^{\circ} \mathrm{C}$ Pine ash sample. (c) Percent compositions of the $\mathrm{C} 1 \mathrm{~s}$ spectra for the unreacted and the reacted ash. 

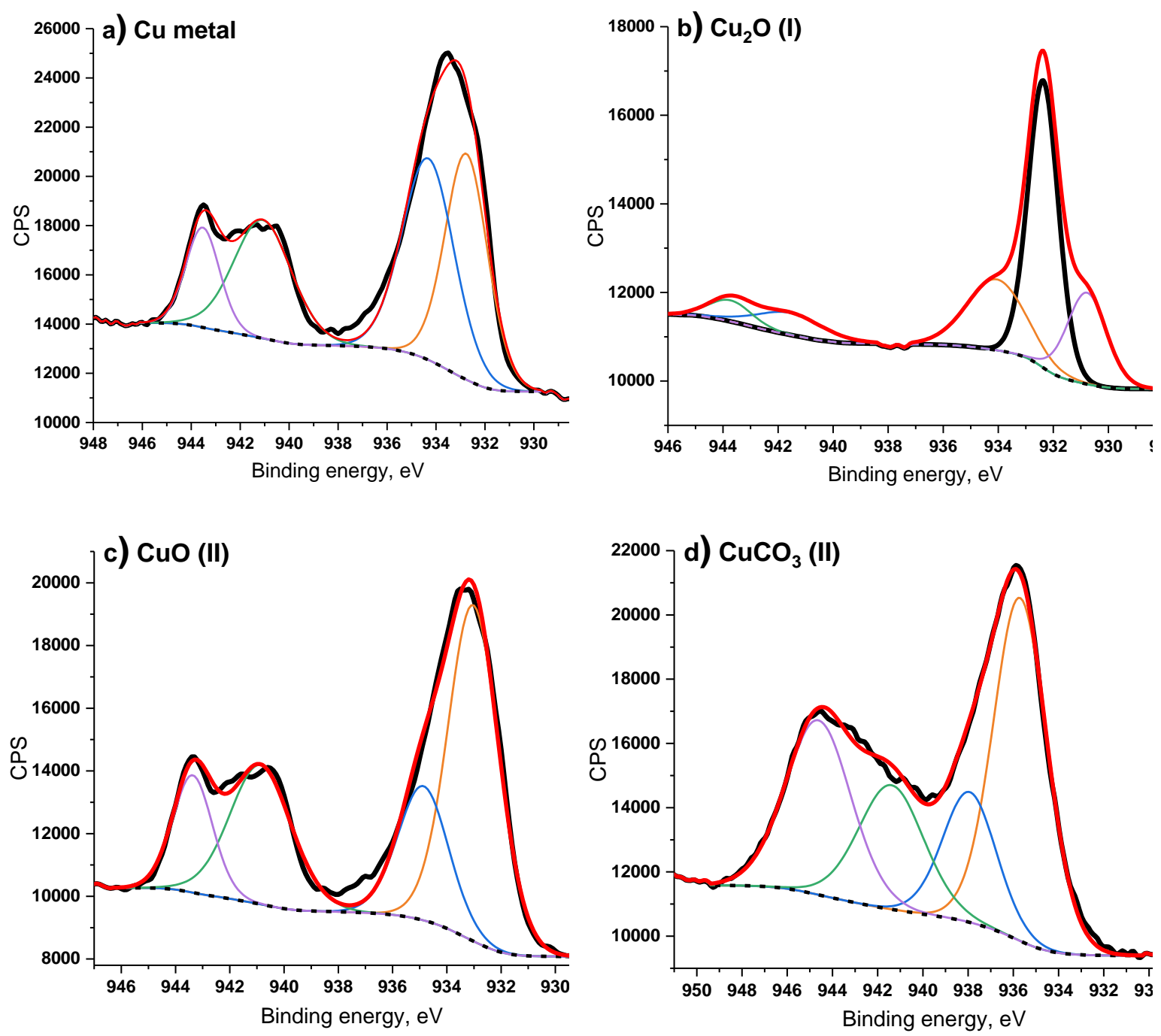

(e) Binding energy values obtained for reference samples using XPS high resolution Cu $2 p$ spectra

Reference Samples

$\mathrm{Cu}$ metal

$\mathrm{Cu}_{2} \mathrm{O}(\mathrm{I})$

$\mathrm{CuO}$ (II)

$\mathrm{CuCO}_{3}(\mathrm{III})$
Binding Energy (eV)

932.8

932.4

934.9

935.7

Figure 10. XPS high-resolution $\mathrm{Cu} 2 \mathrm{p}$ spectra for (a) $\mathrm{Cu}$ metal, (b) $\mathrm{Cu}_{2} \mathrm{O}$ (I), (c) $\mathrm{CuO}$ (II) and (d) $\mathrm{CuCO}_{3}$ (II). (e) The binding energies obtained for the $\mathrm{Cu} 2 \mathrm{p}$ regions for these reference materials are shown. 


\section{References}

(1) Knowles, N.; Dettinger, M. D.; Cayan, D. R., Trends in snowfall versus rainfall in the western United States. Journal of Climate 2006, 19, (18), 4545-4559.

(2) Seager, R.; Tzanova, A.; Nakamura, J., Drought in the southeastern United States: causes, variability over the last millennium, and the potential for future hydroclimate change*. Journal of Climate 2009, 22, (19), 5021-5045.

(3) Williams, A. P.; Allen, C. D.; Macalady, A. K.; Griffin, D.; Woodhouse, C. A.; Meko, D. M.; Swetnam, T. W.; Rauscher, S. A.; Seager, R.; Grissino-Mayer, H. D., Temperature as a potent driver of regional forest drought stress and tree mortality. Nature climate change 2013, 3, (3), 292-297.

(4) Van Mantgem, P. J.; Stephenson, N. L.; Byrne, J. C.; Daniels, L. D.; Franklin, J. F.; Fulé, P. Z.; Harmon, M. E.; Larson, A. J.; Smith, J. M.; Taylor, A. H., Widespread increase of tree mortality rates in the western United States. Science 2009, 323, (5913), 521-524.

(5) Fawcett, P. J.; Werne, J. P.; Anderson, R. S.; Heikoop, J. M.; Brown, E. T.; Berke, M. A.; Smith, S. J.; Goff, F.; Donohoo-Hurley, L.; Cisneros-Dozal, L. M., Extended megadroughts in the southwestern United States during Pleistocene interglacials. Nature 2011, 470, (7335), 518.

(6) Bixby, R. J.; Cooper, S. D.; Gresswell, R. E.; Brown, L. E.; Dahm, C. N.; Dwire, K. A., Fire effects on aquatic ecosystems: an assessment of the current state of the science. Freshwater Science 2015, 34, (4), 1340-1350.

(7) Costa, M. R.; Calvão, A. R.; Aranha, J., Linking wildfire effects on soil and water chemistry of the Marão River watershed, Portugal, and biomass changes detected from Landsat imagery. Applied Geochemistry 2014, 44, 93-102.

(8) Gallaher, B.; Koch, R.; Mullen, K., Quality of storm water runoff at Los Alamos National Laboratory in 2000 with emphasis on the impact of the Cerro Grande Fire. Los Alamos National Laboratory LA-13926 2002, 166.

(9) Burke, M.; Hogue, T.; Kinoshita, A.; Barco, J.; Wessel, C.; Stein, E., Pre-and post-fire pollutant loads in an urban fringe watershed in Southern California. Environmental monitoring and assessment 2013, 185, (12), 10131-10145.

(10) Burton, C. A.; Hoefen, T. M.; Plumlee, G. S.; Baumberger, K. L.; Backlin, A. R.; Gallegos, E.; Fisher, R. N., Trace Elements in Stormflow, Ash, and Burned Soil following the 2009 Station Fire in Southern California. PloS one 2016, 11, (5), e0153372.

(11) Falk, D. A.; Allen, C.; Parmenter, R.; Swetnam, T.; Dils, C., Fire Regimes of Montane Grasslands of the Valles Caldera National Preserve, New Mexico. JFSP: 06-3-1-27 2011, p.2-15.

(12) Cadol, D.; Galanter, A.; Nicholls, P., Distribution and Transport of Pyrogenic Black Carbon in Soils Affected by Wildfires, Valles Caldera, New Mexico, with Implications for Contaminant Transport WRRI Technical Completion Report No. 365. 2015.

(13) Parmenter, R. R.; Oertel, R. W.; Compton, T. S.; Kindschuh, S.; Peyton, M.; Meyer, W.; Caldwell, C.; Jacobi, G. Z.; Myers, O.; Zeigler, M., Fire and floods in the Valles Caldera National Preserve, New Mexico: The 2011 Las Conchas Fire impacts on montane species diversity and food webs. In 97th ESA Annual Convention 2012, 2012.

(14) Dahm, C. N.; Candelaria-Ley, R. I.; Reale, C. S.; Reale, J. K.; Van Horn, D. J., Extreme water quality degradation following a catastrophic forest fire. Freshwater biology 2015, $60,(12), 2584-2599$. 
(15) M. A. Wright; Mahowald, H. E.; Payne, J. E., Fiscal Year 2011 Actions Taken in Response to the Las Conchas Fire at Los Alamos National Laboratory Environmental Protection Division, Los Alamos, New Mexico. 2012, (LA-UR 11-05877).

(16) Sherson, L. R.; Van Horn, D. J.; Gomez-Velez, J. D.; Crossey, L. J.; Dahm, C. N., Nutrient dynamics in an alpine headwater stream: use of continuous water quality sensors to examine responses to wildfire and precipitation events. Hydrological Processes 2015, 29, (14), 3193-3207.

(17) Hohner, A. K.; Cawley, K.; Oropeza, J.; Summers, R. S.; Rosario-Ortiz, F. L., Drinking water treatment response following a Colorado wildfire. Water Research 2016, 105, 187198.

(18) Bodí, M. B.; Martin, D. A.; Balfour, V. N.; Santín, C.; Doerr, S. H.; Pereira, P.; Cerdà, A.; Mataix-Solera, J., Wildland fire ash: production, composition and eco-hydro-geomorphic effects. Earth-Science Reviews 2014, 130, 103-127.

(19) Grusak, M. A.; DellaPenna, D., Improving the nutrient composition of plants to enhance human nutrition and health 1. Annual review of plant biology 1999, 50, (1), 133-161.

(20) Aerts, R.; Chapin, F. S., The mineral nutrition of wild plants revisited: a re-evaluation of processes and patterns. Advances in ecological research 1999, 30, 1-67.

(21) Schmidt, I. K.; Jonasson, S.; Shaver, G.; Michelsen, A.; Nordin, A., Mineralization and distribution of nutrients in plants and microbes in four arctic ecosystems: responses to warming. Plant and Soil 2002, 242, (1), 93-106.

(22) Steenari, B.-M.; Karlsson, L.-G.; Lindqvist, O., Evaluation of the leaching characteristics of wood ash and the influence of ash agglomeration. Biomass and Bioenergy 1999, 16, (2), 119-136.

(23) Cerrato, J. M.; Blake, J. M.; Hirani, C.; Clark, A. L.; Ali, A.-M. S.; Artyushkova, K.; Peterson, E.; Bixby, R. J., Wildfires and water chemistry: effect of metals associated with wood ash. Environmental Science: Processes \& Impacts 2016, 18, (8), 1078-1089.

(24) Bladon, K. D.; Emelko, M. B.; Silins, U.; Stone, M., Wildfire and the Future of Water Supply. Environmental Science \& Technology 2014, 48, (16), 8936-8943.

(25) Emelko, M. B.; Silins, U.; Bladon, K. D.; Stone, M., Implications of land disturbance on drinking water treatability in a changing climate: demonstrating the need for "source water supply and protection" strategies. water research 2011, 45, (2), 461-472.

(26) Smith, H. G.; Sheridan, G. J.; Lane, P. N.; Nyman, P.; Haydon, S., Wildfire effects on water quality in forest catchments: a review with implications for water supply. Journal of Hydrology 2011, 396, (1), 170-192.

(27) Biswas, A.; Blum, J. D.; Klaue, B.; Keeler, G. J., Release of mercury from Rocky Mountain forest fires. Global Biogeochemical Cycles 2007, 21, (1), GB1002.

(28) Ignatavièius, G.; Sakalauskienë, G.; Oškinis, V., Influence of land fires on increase of heavy metal concentrations in river waters of Lithuania. Journal of environmental engineering and landscape management 2006, 14, (1), 46-51.

(29) Silins, U.; Bladon, K. D.; Kelly, E. N.; Esch, E.; Spence, J. R.; Stone, M.; Emelko, M. B.; Boon, S.; Wagner, M. J.; Williams, C. H., Five-year legacy of wildfire and salvage logging impacts on nutrient runoff and aquatic plant, invertebrate, and fish productivity. Ecohydrology 2014, 7, (6), 1508-1523.

(30) Spencer, C. N.; Gabel, K. O.; Hauer, F. R., Wildfire effects on stream food webs and nutrient dynamics in Glacier National Park, USA. Forest Ecology and Management 2003, $178,(1-2), 141-153$. 
(31) Schindler, D. W. In The dilemma of controlling cultural eutrophication of lakes, Proc. R. Soc. B, 2012; The Royal Society: 2012; p rspb20121032.

(32) Audry, S.; Akerman, A.; Riotte, J.; Oliva, P.; Maréchal, J.-C.; Fraysse, F.; Pokrovsky, O. S.; Braun, J.-J., Contribution of forest fire ash and plant litter decay on stream dissolved composition in a sub-humid tropical watershed (Mule Hole, Southern India). Chemical Geology 2014, 372, 144-161.

(33) Cawley, K. M.; Hohner, A. K.; Podgorski, D. C.; Cooper, W. T.; Korak, J. A.; RosarioOrtiz, F. L., Molecular and spectroscopic characterization of water extractable organic matter from thermally altered soils reveal insight into disinfection byproduct precursors. Environmental Science \& Technology 2016, (51(2)), 771-779.

(34) Wang, J.-J.; Dahlgren, R. A.; Erşan, M. S.; Karanfil, T.; Chow, A. T., Wildfire altering terrestrial precursors of disinfection byproducts in forest detritus. Environmental science \& technology 2015, 49, (10), 5921-5929.

(35) Bond, T.; Huang, J.; Templeton, M. R.; Graham, N., Occurrence and control of nitrogenous disinfection by-products in drinking water-a review. Water research 2011, 45, (15), 43414354.

(36) Baghoth, S.; Sharma, S.; Amy, G., Tracking natural organic matter (NOM) in a drinking water treatment plant using fluorescence excitation-emission matrices and PARAFAC. Water research 2011, 45, (2), 797-809.

(37) Muellner, M. G.; Wagner, E. D.; McCalla, K.; Richardson, S. D.; Woo, Y.-T.; Plewa, M. J., Haloacetonitriles vs. regulated haloacetic acids: are nitrogen-containing DBPs more toxic? Environmental science \& technology 2007, 41, (2), 645-651.

(38) Plewa, M. J.; Wagner, E. D.; Jazwierska, P.; Richardson, S. D.; Chen, P. H.; McKague, A. B., Halonitromethane drinking water disinfection byproducts: chemical characterization and mammalian cell cytotoxicity and genotoxicity. Environmental science \& technology 2004, 38, (1), 62-68.

(39) Wang, J.-J.; Dahlgren, R. A.; Chow, A. T., Controlled burning of forest detritus altering spectroscopic characteristics and chlorine reactivity of dissolved organic matter: effects of temperature and oxygen availability. Environmental science \& technology 2015, 49, (24), 14019-14027.

(40) Keeley, J. E., Fire intensity, fire severity and burn severity: a brief review and suggested usage. International Journal of Wildland Fire 2009, 18, (1), 116-126.

(41) Úbeda, X.; Pereira, P.; Outeiro, L.; Martin, D., Effects of fire temperature on the physical and chemical characteristics of the ash from two plots of cork oak (Quercus suber). Land degradation \& development 2009, 20, (6), 589-608.

(42) Bodí, M. B.; Mataix-Solera, J.; Doerr, S. H.; Cerdà, A., The wettability of ash from burned vegetation and its relationship to Mediterranean plant species type, burn severity and total organic carbon content. Geoderma 2011, 160, (3-4), 599-607.

(43) Moody, J. A.; Kinner, D. A.; Úbeda, X., Linking hydraulic properties of fire-affected soils to infiltration and water repellency. Journal of Hydrology 2009, 379, (3-4), 291-303.

(44) Catalano, J. G.; Huhmann, B. L.; Luo, Y.; Mitnick, E. H.; Slavney, A.; Giammar, D. E., Metal release and speciation changes during wet aging of coal fly ashes. Environmental science \& technology 2012, 46, (21), 11804-11812.

(45) Ulery, A.; Graham, R.; Amrhein, C., Wood-ash composition and soil $\mathrm{pH}$ following intense burning. Soil Science 1993, 156, (5), 358-364. 
(46) Misra, M. K.; Ragland, K. W.; Baker, A. J., Wood ash composition as a function of furnace temperature. Biomass and Bioenergy 1993, 4, (2), 103-116.

(47) Dennison, P. E.; Charoensiri, K.; Roberts, D. A.; Peterson, S. H.; Green, R. O., Wildfire temperature and land cover modeling using hyperspectral data. Remote Sensing of Environment 2006, 100, (2), 212-222.

(48) Taylor, S.; Wotton, B.; Alexander, M.; Dalrymple, G., Variation in wind and crown fire behaviour in a northern jack pine black spruce forest. Canadian Journal of Forest Research 2004, 34, (8), 1561-1576.

(49) Marcelli, T.; Santoni, P. A.; Simeoni, A.; Leoni, E.; Porterie, B., Fire spread across pine needle fuel beds: characterization of temperature and velocity distributions within the fire plume. International journal of wildland fire 2004, 13, (1), 37-48.

(50) Khan, S. J.; Deere, D.; Leusch, F. D.; Humpage, A.; Jenkins, M.; Cunliffe, D., Extreme weather events: Should drinking water quality management systems adapt to changing risk profiles? Water research 2015, 85, 124-136.

(51) Etiegni, L.; Campbell, A., Physical and chemical characteristics of wood ash. Bioresource technology 1991, 37, (2), 173-178.

(52) Pereira, P.; Úbeda, X.; Martin, D. A., Fire severity effects on ash chemical composition and water-extractable elements. Geoderma 2012, 191, 105-114.

(53) Jones, D. L.; Quilliam, R., Metal contaminated biochar and wood ash negatively affect plant growth and soil quality after land application. Journal of hazardous materials 2014, 276, 362-370.

(54) Lucchini, P.; Quilliam, R.; DeLuca, T. H.; Vamerali, T.; Jones, D. L., Increased bioavailability of metals in two contrasting agricultural soils treated with waste woodderived biochar and ash. Environmental Science and Pollution Research 2014, 21, (5), 3230-3240.

(55) Saeed, A.; Akhter, M. W.; Iqbal, M., Removal and recovery of heavy metals from aqueous solution using papaya wood as a new biosorbent. Separation and purification technology 2005, 45, (1), 25-31.

(56) Yang, X.-B.; Ying, G.-G.; Peng, P.-A.; Wang, L.; Zhao, J.-L.; Zhang, L.-J.; Yuan, P.; He, H.-P., Influence of biochars on plant uptake and dissipation of two pesticides in an agricultural soil. Journal of agricultural and food chemistry 2010, 58, (13), 7915-7921.

(57) Ahmad, M.; Rajapaksha, A. U.; Lim, J. E.; Zhang, M.; Bolan, N.; Mohan, D.; Vithanage, M.; Lee, S. S.; Ok, Y. S., Biochar as a sorbent for contaminant management in soil and water: a review. Chemosphere 2014, 99, 19-33.

(58) Ippolito, J.; Strawn, D.; Scheckel, K.; Novak, J.; Ahmedna, M.; Niandou, M., Macroscopic and molecular investigations of copper sorption by a steam-activated biochar. Journal of environmental quality 2012, 41, (4), 1150-1156.

(59) Uchimiya, M.; Wartelle, L. H.; Klasson, K. T.; Fortier, C. A.; Lima, I. M., Influence of pyrolysis temperature on biochar property and function as a heavy metal sorbent in soil. Journal of Agricultural and Food Chemistry 2011, 59, (6), 2501-2510.

(60) Beesley, L.; Marmiroli, M., The immobilisation and retention of soluble arsenic, cadmium and zinc by biochar. Environmental Pollution 2011, 159, (2), 474-480.

(61) Park, J. H.; Lamb, D.; Paneerselvam, P.; Choppala, G.; Bolan, N.; Chung, J.-W., Role of organic amendments on enhanced bioremediation of heavy metal (loid) contaminated soils. Journal of hazardous materials 2011, 185, (2), 549-574. 
(62) Zhang, X.; Wang, H.; He, L.; Lu, K.; Sarmah, A.; Li, J.; Bolan, N. S.; Pei, J.; Huang, H., Using biochar for remediation of soils contaminated with heavy metals and organic pollutants. Environmental Science and Pollution Research 2013, 20, (12), 8472-8483.

(63) Uchimiya, M.; Bannon, D. I.; Wartelle, L. H.; Lima, I. M.; Klasson, K. T., Lead retention by broiler litter biochars in small arms range soil: impact of pyrolysis temperature. Journal of agricultural and food chemistry 2012, 60, (20), 5035-5044.

(64) Hsu, N.-H.; Wang, S.-L.; Lin, Y.-C.; Sheng, G. D.; Lee, J.-F., Reduction of Cr (VI) by crop-residue-derived black carbon. Environmental science \& technology 2009, 43, (23), 8801-8806.

(65) Hsu, N.-H.; Wang, S.-L.; Liao, Y.-H.; Huang, S.-T.; Tzou, Y.-M.; Huang, Y.-M., Removal of hexavalent chromium from acidic aqueous solutions using rice straw-derived carbon. Journal of hazardous materials 2009, 171, (1), 1066-1070.

(66) Dong, X.; Ma, L. Q.; Li, Y., Characteristics and mechanisms of hexavalent chromium removal by biochar from sugar beet tailing. Journal of hazardous materials 2011, 190, (1), 909-915.

(67) Fang, Q.; Chen, B.; Lin, Y.; Guan, Y., Aromatic and hydrophobic surfaces of wood-derived biochar enhance perchlorate adsorption via hydrogen bonding to oxygen-containing organic groups. Environmental science \& technology 2013, 48, (1), 279-288.

(68) Xiao, X.; Chen, B.; Chen, Z.; Zhu, L.; Schnoor, J. L., Insight into Multiple and Multi-level Structures of Biochars and Their Potential Environmental Applications: A Critical Review. Environmental science \& technology 2018.

(69) de Mendonça, F. G.; da Cunha, I. T.; Soares, R. R.; Tristão, J. C.; Lago, R. M., Tuning the surface properties of biochar by thermal treatment. Bioresource Technology 2017, (246), 28-33.

(70) Etiegni, L.; Campbell, A.; Mahler, R., Evaluation of wood ash disposal on agricultural land. I. Potential as a soil additive and liming agent. Communications in Soil Science and Plant Analysis 1991, 22, (3-4), 243-256.

(71) Omil, B.; Piñeiro, V.; Merino, A., Trace elements in soils and plants in temperate forest plantations subjected to single and multiple applications of mixed wood ash. Science of the total environment 2007, 381, (1-3), 157-168.

(72) Chirenje, T.; Ma, L. Q.; Lu, L., Retention of $\mathrm{Cd}, \mathrm{Cu}, \mathrm{Pb}$ and $\mathrm{Zn}$ by wood ash, lime and fume dust. Water, Air, \& Soil Pollution 2006, 171, (1), 301-314.

(73) Tsai, K.-P.; Uzun, H.; Karanfil, T.; Chow, A. T., Dynamic Changes of Disinfection Byproduct Precursors following Exposures of Microcystis aeruginosa to Wildfire Ash Solutions. Environmental Science \& Technology 2017, 51, (15), 8272-8282.

(74) Stein, E. D.; Brown, J. S.; Hogue, T. S.; Burke, M. P.; Kinoshita, A., Stormwater contaminant loading following southern California wildfires. Environmental toxicology and chemistry 2012, 31, (11), 2625-2638.

(75) Spracklen, D. V.; Mickley, L. J.; Logan, J. A.; Hudman, R. C.; Yevich, R.; Flannigan, M. D.; Westerling, A. L., Impacts of climate change from 2000 to 2050 on wildfire activity and carbonaceous aerosol concentrations in the western United States. Journal of Geophysical Research: Atmospheres 2009, 114, (D20), 2156-2202.

(76) Westerling, A. L.; Hidalgo, H. G.; Cayan, D. R.; Swetnam, T. W., Warming and Earlier Spring Increase Western U.S. Forest Wildfire Activity. Science 2006, 313, (5789), 940943. 
(77) Ford-Schmid, R. 2011 Las Conchas Fire Impacts to Water Quality in the Rio Grande; New Mexico Environment Department: 2011.

(78) Muldavin, E.; Neville, P.; Jackson, C.; Neville, T., A Vegetation Map of Valles Caldera National Preserve, New Mexico. Natural Heritage: Albuquerque, New Mexico 2006, 59.

(79) Muldavin, E.; Tonne, P., A vegetation survey and preliminary ecological assessment of Valles Caldera National Preserve, New Mexico. Report for Cooperative Agreement 2003, (01CRAG0014), 27-31.

(80) District, M. R. G. C., An Investigation into the Potential Impacts of Watershed Restoration and Wildfire on Water Yields and Water Supply Resilience in the Rio Grande Water Fund Project Area. 2017.

(81) Federation, W. E.; Association, A. P. H., Standard methods for the examination of water and wastewater. American Public Health Association (APHA): Washington, DC, USA 2005.

(82) Team, R. C., R: A language and environment for statistical computing [Internet]. Vienna, Austria: R Foundation for Statistical Computing; 2014. In 2015.

(83) Seifert, E., OriginPro 9.1: Scientific Data Analysis and Graphing Software, Software Review. In ACS Publications: 2014; pp 1552-1552.

(84) H., J. S. H. Water Quality Survey Summary for the Valles Caldera National Preserve Watershed; Surface Water Quality Bureau, New Mexico Environment Department: 2006.

(85) East Fork Jemez below La Jara Creek. In NM Environmental Dept./SWQB.

(86) Burt, R.; Wilson, M.; Mays, M.; Lee, C., Major and trace elements of selected pedons in the USA. Journal of Environmental Quality 2003, 32, (6), 2109-2121.

(87) Hochmuth, G.; Maynard, D.; Vavrina, C.; Hanlon, E.; Simonne, E., Plant tissue analysis and interpretation for vegetable crops in Florida. Gainsville, FL: Florida Cooperative Extension Service SS-VEC-42 1991.

(88) Reimann, C.; Ottesen, R. T.; Andersson, M.; Arnoldussen, A.; Koller, F.; Englmaier, P., Element levels in birch and spruce wood ashes-green energy? Science of the total environment 2008, 393, (2), 191-197.

(89) Gabet, E. J.; Bookter, A., Physical, chemical and hydrological properties of Ponderosa pine ash. International Journal of Wildland Fire 2011, 20, (3), 443-452.

(90) O'connell, M.; Baldwin, D. S.; Robertson, A.; Rees, G., Release and bioavailability of dissolved organic matter from floodplain litter: influence of origin and oxygen levels. Freshwater Biology 2000, 45, (3), 333-342.

(91) Moore, T.; Dalva, M., Some controls on the release of dissolved organic carbon by plant tissues and soils. Soil Science 2001, 166, (1), 38-47.

(92) von Gunten, K.; Alam, M. S.; Hubmann, M.; Ok, Y. S.; Konhauser, K. O.; Alessi, D. S., Modified sequential extraction for biochar and petroleum coke: Metal release potential and its environmental implications. Bioresource technology 2017, 236, 106-110.

(93) Bogusz, A.; Oleszczuk, P.; Dobrowolski, R., Application of laboratory prepared and commercially available biochars to adsorption of cadmium, copper and zinc ions from water. Bioresource technology 2015, 196, 540-549.

(94) Alam, M. S.; Swaren, L.; von Gunten, K.; Cossio, M.; Bishop, B.; Robbins, L. J.; Hou, D.; Flynn, S. L.; Ok, Y. S.; Konhauser, K. O., Application of surface complexation modeling to trace metals uptake by biochar-amended agricultural soils. Applied Geochemistry 2017, (in press), 1-10. 
(95) Mohan, D.; Pittman, C. U., Arsenic removal from water/wastewater using adsorbents-a critical review. Journal of hazardous materials 2007, 142, (1), 1-53.

(96) Bhattacharya, A.; Naiya, T.; Mandal, S.; Das, S., Adsorption, kinetics and equilibrium studies on removal of $\mathrm{Cr}$ (VI) from aqueous solutions using different low-cost adsorbents. Chemical engineering journal 2008, 137, (3), 529-541.

(97) Kotaś, J.; Stasicka, Z., Chromium occurrence in the environment and methods of its speciation. Environmental pollution 2000, 107, (3), 263-283.

(98) Bauer, P.; Elbaum, R.; Weiss, I. M., Calcium and silicon mineralization in land plants: transport, structure and function. Plant Science 2011, 180, (6), 746-756.

(99) Franceschi, V. R.; Nakata, P. A., Calcium oxalate in plants: formation and function. Annu. Rev. Plant Biol. 2005, 56, 41-71.

(100) Harvey, O. R.; Herbert, B. E.; Rhue, R. D.; Kuo, L.-J., Metal interactions at the biocharwater interface: energetics and structure-sorption relationships elucidated by flow adsorption microcalorimetry. Environmental science \& technology 2011, 45, (13), 55505556.

(101) Myers-Pigg, A. N.; Louchouarn, P.; Amon, R. M.; Prokushkin, A.; Pierce, K.; Rubtsov, A., Labile pyrogenic dissolved organic carbon in major Siberian Arctic rivers: Implications for wildfire-stream metabolic linkages. Geophysical Research Letters 2015, 42, (2), 377385.

(102) Lima, I. M.; Boateng, A. A.; Klasson, K. T., Physicochemical and adsorptive properties of fast-pyrolysis bio-chars and their steam activated counterparts. Journal of chemical technology and biotechnology 2010, 85, (11), 1515-1521. 